Utah State University

DigitalCommons@USU

$10-26-2015$

\title{
Restoration Handbook for Sagebrush Steppe Ecosystems with Emphasis on Greater Sage-Grouse Habitat-Part 1. Concepts for Understanding and Applying Restoration
}

\author{
David A. Pyke \\ U.S. Geological Survey, Forest and Rangeland Ecosystem Science Center \\ Jeanne C. Chambers \\ U.S. Forest Service, Rocky Mountain Research Station \\ Mike Pellant \\ Bureau of Land Management \\ Steven T. Knick \\ U.S. Geological Survey, Forest and Rangeland Ecosystem Science Center \\ Richard F. Miller \\ Oregon State University \\ Jeffrey L. Beck

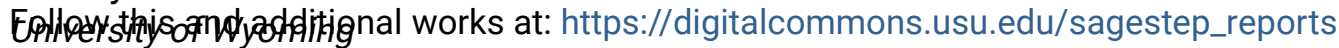 \\ Part of the Life Sciences Commons
}

See nexí page for adaiitionai authiors

Recommended Citation

Pyke, D.A., Chambers, J.C., Pellant, M., Knick, S.T., Miller, R,F., Beck, J.L., Doescher, P.S., Schupp, E.W., Roundy, B.A., Brunson, M., and Mclver, J.D., 2015, Restoration handbook for sagebrush steppe ecosystems with emphasis on greater sage-grouse habitat-Part 1. Concepts for understanding and applying restoration: U.S. Geological Survey Circular 1416, 44 p., http://dx.doi.org/10.3133/cir1416.

This Report is brought to you for free and open access by the Publications at DigitalCommons@USU. It has been accepted for inclusion in Reports by an authorized administrator of DigitalCommons@USU. For more information, please contact digitalcommons@usu.edu.

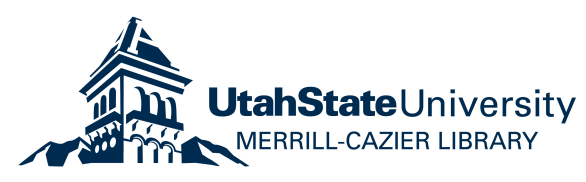




\section{Authors}

David A. Pyke, Jeanne C. Chambers, Mike Pellant, Steven T. Knick, Richard F. Miller, Jeffrey L. Beck, Paul S. Doescher, Eugene W. Schupp, Bruce A. Roundy, Mark W. Brunson, and James D. Mclver 
Prepared in cooperation with U.S. Joint Fire Science Program and National Interagency Fire Center, Bureau of Land Management, Great Northern Landscape Conservation, and Western Association of Fish and Wildlife Agencies

\section{Restoration Handbook for Sagebrush Steppe Ecosystems with Emphasis on Greater Sage-Grouse Habitat- Part 1. Concepts for Understanding and Applying Restoration}

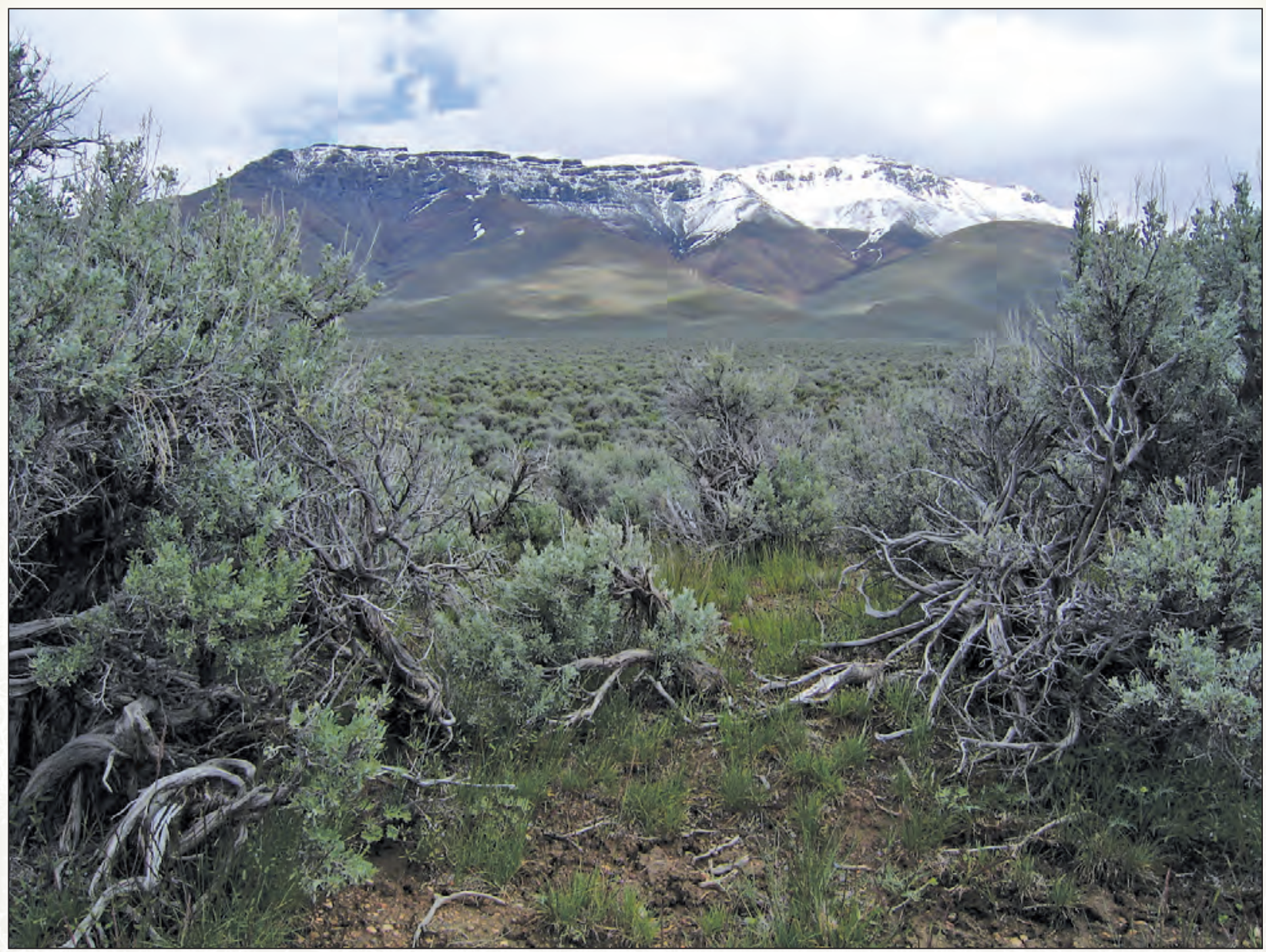

Circular 1416

U.S. Department of the Interior

U.S. Geological Survey 
Cover: Photograph showing Wyoming big sagebrush community near Winnemucca, Nevada. (Photograph by David Pyke, U.S. Geological Survey, 2005.) 


\section{Restoration Handbook for Sagebrush Steppe Ecosystems with Emphasis on Greater Sage-Grouse Habitat-Part 1. Concepts for Understanding and Applying Restoration}

By David A. Pyke, Jeanne C. Chambers, Mike Pellant, Steven T. Knick, Richard F. Miller, Jeffrey L. Beck, Paul S. Doescher, Eugene W. Schupp, Bruce A. Roundy, Mark Brunson, and James D. Mclver

Prepared in cooperation with U.S. Joint Fire Science Program and National Interagency Fire Center, Bureau of Land Management, Great Northern Landscape Conservation, and Western Association of Fish and Wildlife Agencies

Circular 1416 


\title{
U.S. Department of the Interior SALLY JEWELL, Secretary
}

\section{U.S. Geological Survey \\ Suzette M. Kimball, Acting Director}

\author{
U.S. Geological Survey, Reston, Virginia: 2015
}

For more information on the USGS —-the Federal source for science about the Earth, its natural and living resources, natural hazards, and the environment-visit http://www.usgs.gov or call 1-888-ASK-USGS.

For an overview of USGS information products, including maps, imagery, and publications, visit http://www.usgs.gov/pubprod/.

Any use of trade, firm, or product names is for descriptive purposes only and does not imply endorsement by the U.S. Government.

Although this information product, for the most part, is in the public domain, it also may contain copyrighted materials as noted in the text. Permission to reproduce copyrighted items must be secured from the copyright owner.

Suggested citation:

Pyke, D.A., Chambers, J.C., Pellant, M., Knick, S.T., Miller, R,F., Beck, J.L., Doescher, P.S., Schupp, E.W., Roundy, B.A., Brunson, M., and Mclver, J.D., 2015, Restoration handbook for sagebrush steppe ecosystems with emphasis on greater sage-grouse habitat-Part 1. Concepts for understanding and applying restoration: U.S. Geological Survey Circular 1416, 44 p., http://dx.doi.org/10.3133/cir1416.

\section{Library of Congress Cataloging-in-Publication Data}

Names: Pyke, David A. | Joint Fire Science Program (U.S.)

Title: Restoration handbook for sagebrush steppe ecosystems with emphasis on greater sage-grouse habitat / prepared in cooperation with U.S. Joint Fire Science Program and National Interagency Fire Center, Bureau of Land Management, Great Northern Landscape Conservation, and Western Association of Fish and Wildlife Agencies.

Description: Reston, Virginia : U.S. Geological Survey, 2015- | Series:

Circular ; 1416, 1418 | Includes bibliographical references and index. Identifiers: LCCN 2015035308| ISBN 9781411339682 (pt. 1 : pbk. : alk. paper) | ISBN 9781411339972 (pt. 2 : pbk. : alk. paper)

Subjects: LCSH: Sagebrush steppe ecology--United States. | Steppe restoration--United States. | Sage grouse--Habitat--Conservation--United States.

Classification: LCC QH104 .R467 2015 | DDC 333.74/153--dc23

LC record available at http://lccn.loc.gov/2015035308 


\section{Preface}

This Restoration Handbook consists of three parts with the same main title, "Restoration Handbook for Sagebrush Steppe Ecosystems with Emphasis on Greater Sage-Grouse Habitat." These parts provide an approach for effective implementation of restoration practices in sagebrush steppe ecosystems. The current document summarizes the literature and synthesizes core concepts that are necessary for a practitioner/manager to apply tools to help make landscape and site-specific decisions. Landscape-level decision tools are designed to help managers prioritize resource allocation among multiple potential restoration projects for achieving the greatest benefit at the landscape level. We are examining how restoration of sagebrush steppe can benefit habitat for sage-grouse because of the timeliness of the upcoming decision to list sage-grouse under the Endangered Species Act. In addition, we are emphasizing greater sage-grouse because they are an umbrella species within this region where other wildlife species that depend on resilient sagebrush grassland communities will benefit from this restoration. There are additional objectives for restoration of sagebrush grasslands beyond greater sage-grouse habitat, for example, improving rangeland biological diversity, reducing and controlling invasive plant dominance, and improving the stability of livestock forage. For site-level decisions, managers will decide to use passive or active restoration techniques and will learn how to select appropriate plant species and techniques for restoration of sagebrush ecosystems. Landscape prioritization tools and project-level restoration tools use concepts of ecosystem resilience to disturbances and resistance to invasion by annual grasses. We stress that these invasions are the largest threat to sagebrush steppe ecosystems and that restoration, if successful, is a means for reducing this threat and improving greater sage-grouse habitat. Decisions at the landscape- and site-level will be enhanced through knowledge gained by understanding and applying concepts presented in this document. 

QtzL

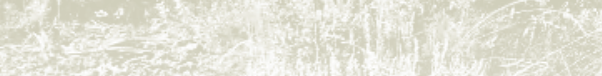




\section{Contents}

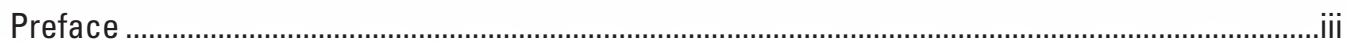

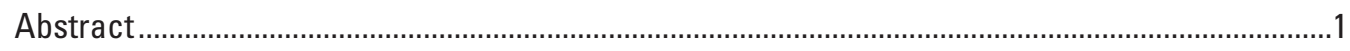

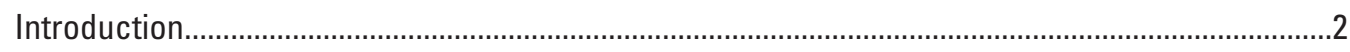

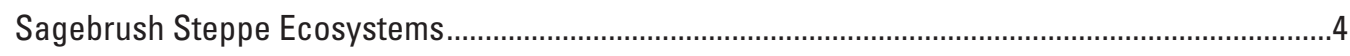

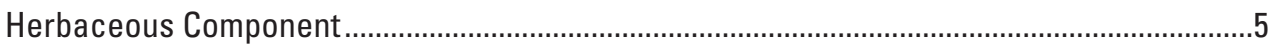

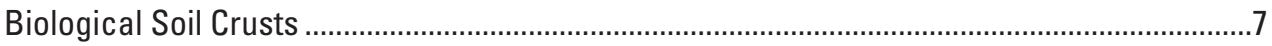

Plant Responses to Fire and Defoliation .............................................................................. 10

Resilience to Disturbance and Resistance to Invasions by Annual Grasses in Sagebrush

Steppe Ecosystems....................................................................................................

Soils and Ecological Site Descriptions — Roles in Restoration .........................................................15

Soil Moisture and Soil Temperature Regimes as Indicators of Resilience and

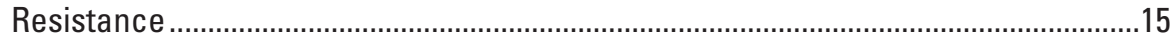

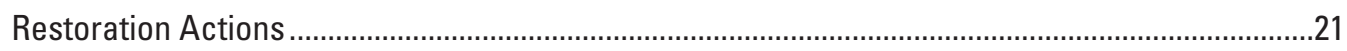

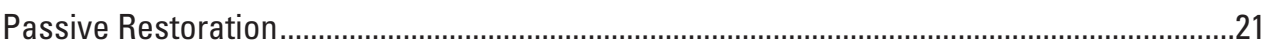

Active Restoration Compared to Rehabilitation ..........................................................................23

Landscape as a Concept for Restoration ............................................................................................24

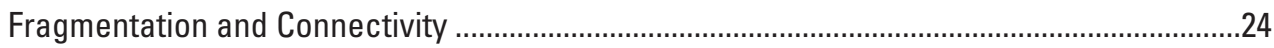

Hierarchical Arrangements in Landscapes .................................................................................25

Sage-Grouse as a Landscape Species ...................................................................................25

Sage-Grouse Seasonal Habitat Requirements .....................................................................28

Restoration Methods of Sagebrush Steppe Ecosystems for Sage-Grouse Habitat........................30

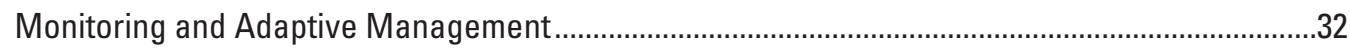

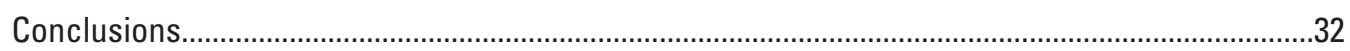

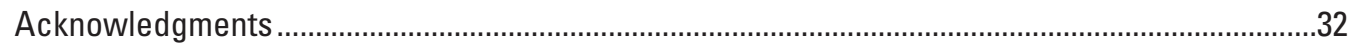

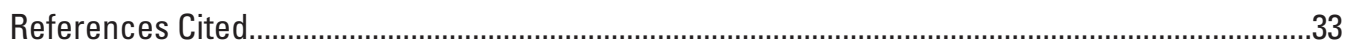

Appendix A. Scientific Name with Synonyms and Corresponding Common Name with Synonyms for Species Referenced in This Report .................................................................41 


\section{Figures}

1. Map showing percentage of landscape sagebrush cover in the seven floristic provinces included in the sagebrush steppe.

2. Diagram showing sagebrush taxa in the Great Basin and Columbia Basin positioned along gradients of soil temperature and soil moisture

3. Diagram showing relationship between soil temperature-moisture regimes and productivity or fuel loads with example plant communities (photographs) distributed along the gradient

4. Diagrams showing resilience to disturbance $(A)$ and resistance to cheatgrass $(B)$ over a typical temperature/precipitation gradient in the Great Basin.

5. Map showing soil moisture and soil temperature regimes that characterize the greater sage-grouse management zones

6. Diagram showing state and transition conceptual model depicting successional dynamics for a generalized warm and dry sagebrush grassland community.

7. Diagram showing hierarchy of patterns across spatial and temporal scales and the relationship to sage-grouse and their habitat.

8. Map showing landscape cover of sagebrush $(<25,25-65$, and $>65$ percent) for the greater sage-grouse management zones.

9. Graph showing proportion of sage-grouse leks and habitat similarity index (HSI) as related to the percentage of landscape cover of sagebrush

\section{Tables}

1. Tolerance levels for shrubs and perennial forbs to fire in the Great Basin and Columbia River Plateau provinces.

2. Major sagebrush ecological types for California, Idaho, Nevada, Oregon, Utah, and Washington.

3. Minimum height and canopy coverage recommendations for sagebrush and herbaceous (grass-forb) components in seasonal sage-grouse habitats.

4. Forbs listed as foods for sage-grouse. 


\section{Conversion Factors}

Inch/Pound to International System of Units

\begin{tabular}{lcl}
\hline & Multiply & \multicolumn{1}{c}{ To obtain } \\
\hline inch (in.) & Length & \\
inch (in.) & 2.54 & centimeter $(\mathrm{cm})$ \\
mile (mi) & 25.4 & millimeter (mm) \\
\hline \multicolumn{4}{c}{ kilometer $(\mathrm{km})$} \\
\hline acre & 1.609 & \\
acre & Area & square meter $\left(\mathrm{m}^{2}\right)$ \\
acre & 4,047 & hectare $($ ha) \\
square mile $\left(\mathrm{mi}^{2}\right)$ & 0.4047 & square kilometer $\left(\mathrm{km}^{2}\right)$ \\
square mile (mi $\left.{ }^{2}\right)$ & 0.004047 & hectare $($ ha) \\
& 259.0 & square kilometer $\left(\mathrm{km}^{2}\right)$ \\
\hline pound, avoirdupois $(\mathrm{lb})$ & 2.590 & \\
\hline
\end{tabular}

International System of Units to Inch/Pound

\begin{tabular}{lcl}
\hline \multicolumn{1}{c}{ Multiply } & By & To obtain \\
\hline centimeter $(\mathrm{cm})$ & Length & inch (in.) \\
kilometer $(\mathrm{km})$ & 0.3937 & mile (mi) \\
\hline square meter $\left(\mathrm{m}^{2}\right)$ & 0.6214 & acre \\
hectare $($ ha) & Area & acre \\
square hectometer $\left(\mathrm{hm}^{2}\right)$ & 0.0002471 & acre \\
square kilometer $\left(\mathrm{km}^{2}\right)$ & 2.471 & acre \\
square centimeter $\left(\mathrm{cm}^{2}\right)$ & 2.471 & square foot $\left(\mathrm{ft}^{2}\right)$ \\
square meter $\left(\mathrm{m}^{2}\right)$ & 247.1 & square foot $\left(\mathrm{ft}^{2}\right)$ \\
square centimeter $\left(\mathrm{cm}^{2}\right)$ & 0.001076 & square inch $\left(\mathrm{ft}^{2}\right)$ \\
hectare $($ ha) & 10.76 & square mile $\left(\mathrm{mi}^{2}\right)$ \\
square kilometer $\left(\mathrm{km}^{2}\right)$ & 0.1550 & square mile $\left(\mathrm{mi}^{2}\right)$ \\
\hline & 0.003861 & \\
\hline kilogram $(\mathrm{kg})$ & 0.3861 & pound avoirdupois $(\mathrm{lb})$ \\
\hline
\end{tabular}

Temperature in degrees Celsius $\left({ }^{\circ} \mathrm{C}\right)$ may be converted to degrees Fahrenheit $\left({ }^{\circ} \mathrm{F}\right)$ as ${ }^{\circ} \mathrm{F}=\left(1.8 \times{ }^{\circ} \mathrm{C}\right)+32$.

Temperature in degrees Fahrenheit $\left({ }^{\circ} \mathrm{F}\right)$ may be converted to degrees Celsius $\left({ }^{\circ} \mathrm{C}\right)$ as ${ }^{\circ} \mathrm{C}=\left({ }^{\circ} \mathrm{F}-32\right) / 1.8$.

\section{Datum}

Horizontal coordinate information is referenced to the North American Datum of 1983 (NAD 83). 



\title{
Restoration Handbook for Sagebrush Steppe Ecosystems with Emphasis on Greater Sage-Grouse Habitat-Part 1. Concepts for Understanding and Applying Restoration
}

\author{
By David A. Pyke', Jeanne C. Chambers², Mike Pellant ${ }^{3}$, Steven T. Knick', Richard F. Miller ${ }^{4}$, Jeffrey L. Beck ${ }^{5}$, \\ Paul S. Doescher ${ }^{6}$, Eugene W. Schupp ${ }^{7}$, Bruce A. Roundy ${ }^{8}$, Mark Brunson ${ }^{9}$, and James D. Mclver ${ }^{10}$
}

\section{Abstract}

Sagebrush steppe ecosystems in the United States currently occur on only about one-half of their historical land area because of changes in land use, urban growth, and degradation of land, including invasions of non-native plants. The existence of many animal species depends on the existence of sagebrush steppe habitat. The greater sage-grouse (Centrocercus urophasianus) is a landscapedependent bird that requires intact habitat and combinations of sagebrush and perennial grasses to exist. In addition, other sagebrush-obligate animals also have similar requirements and restoration of landscapes for greater sage-grouse also will benefit these animals. Once sagebrush lands are degraded, they may require restoration actions to make those lands viable habitat for supporting sagebrushobligate animals. This restoration handbook is the first in a three-part series on restoration of sagebrush ecosystems. In Part 1, we discuss concepts surrounding landscape and restoration ecology of sagebrush ecosystems and greater sage-grouse that habitat managers and restoration practitioners need to know to make informed decisions regarding where and how to restore specific areas. We will describe the plant dynamics of sagebrush steppe ecosystems and their responses to major disturbances, fire, and defoliation. We will introduce the concepts of ecosystem resilience to disturbances and resistance to invasions of annual grasses within sagebrush steppe. An introduction to soils and ecological site information will provide insights into the specific plants that can be restored in a location. Soil temperature and moisture regimes are described as a tool for determining resilience and resistance and the potential for various restoration actions. Greater sage-grouse are considered landscape birds that require large areas of intact sagebrush steppe; therefore, we describe concepts of landscape ecology that aid our decisions regarding habitat restoration. We provide a brief overview of restoration techniques for sage-grouse habitat restoration. We conclude with a description of the critical nature of monitoring for adaptive management of sagebrush steppe restoration at landscape- and project-specific levels.

\footnotetext{
${ }^{1}$ U.S. Geological Survey, Forest and Rangeland Ecosystem Science Center.

${ }^{2}$ U.S. Forest Service, Rocky Mountain Research Station.

${ }^{3}$ Bureau of Land Management.

${ }^{4}$ Eastern Oregon Agricultural Research Center, Oregon State University, Corvallis.

${ }^{5}$ Department of Ecosystem Science and Management, University of Wyoming, Laramie.

${ }^{6}$ Department of Forest Ecosystems and Society, Oregon State University, Corvallis.

${ }^{7}$ Department of Wildland Resources and the Ecology Center, Utah State University, Logan.

${ }^{8}$ Department of Plant and Wildlife Sciences, Brigham Young University, Provo.

${ }^{9}$ Department of Environment and Society and the Ecology Center, Utah State University, Logan.

${ }^{10}$ Eastern Oregon Agricultural Research Center, Oregon State University, Union.
} 


\section{Introduction}

Sagebrush steppe, one of the largest ecosystems in North America, occurs widely across the Western United States (fig. 1). This ecosystem ranges from eastern slopes of the Cascade and Sierra Nevada mountains to western parts of the Great Plains and from the southern parts of the western Canadian provinces to the Southern Great Basin and Colorado Plateau. Sagebrush steppe ecosystems exist in locations with hot, dry summers, and cool to cold, moist winters. They are associated with woodlands and forests at high elevations and salt desert ecosystems at low elevations in the Great Basin and Colorado Plateau; and with grasslands in the western Great Plains with a mix of warm- and cool-season plants as summer precipitation becomes more consistent. Sagebrush phases of these communities are dominated by one of a number of big sagebrush (Artemisia tridentata) subspecies, but can include a host of other sagebrush species that are restricted largely to unique soil and climate combinations (Miller and others, 2011). Sagebrush communities once dominated an estimated 529,000 $\mathrm{km}^{2}$ (about 131,000 million acres), but due to human land use conversions and plant invasions, sagebrush communities are now estimated to exist on only about 55 percent of their historical land areas (Miller and others, 2011).

The vast sea of sagebrush described by early explorers has changed in three fundamental ways. First, the total quantity of the landscape dominated by sagebrush has decreased in many regions as a result of many causes (Miller and others, 2011). Second, the composition of the sagebrush community has changed in two ways - (1) at low elevations, an increasing variety of non-native plants, mostly annual grasses, have become dominant; and (2) at high elevations, trees have expanded downslope to dominate sagebrush communities. Third, sagebrush lands have changed from a continuous sagebrush landscape containing small areas dominated by herbaceous plants or other shrubs to lands that are more fragmented with large patches of herbaceous plants, primarily non-native annual grasses, with smaller patches dominated by sagebrush (Leu and Hanser, 2011; Shepherd and others, 2011). Each of these changes alters the primary way a sagebrush landscape functions by altering for example, soil stability, nutrient cycling, water infiltration and storage, and biological diversity (Miller and others, 2011) as well as its suitability to sagebrush-dependent wildlife such as greater sage-grouse (Centrocercus urophasianus; hereinafter, sage-grouse) (Knick and others, 2003).
Some locations may still maintain most of the sagebrush steppe plant species, but may not have the desired combination of plant species (that is, composition) to meet management objectives. Consequently, restoration actions may consider avoiding risk of further degradation because locations lack sufficient levels of plant species to be resilient to the restoration disturbance or to resist increases of invasive species (Chambers and others, 2013). For example, habitat guidelines for sage-grouse (Connelly and others, 2000) suggest minimum grass and forb ground cover levels in combination with dominant cover of sagebrush. If current conditions do not meet these levels, then managers may consider restoration alternatives, such as changing current management to encourage increases in cover of grasses and forbs. Alternatively, to reduce woody fuels, managers may consider using techniques such as fire or mowing that may have short-term detrimental effects on existing sagebrush thus lowering the site value to sagebrush dependent wildlife such as sage-grouse (Beck and others, 2012). Both alternatives require adequate levels of desired perennial plants to remain resilient to disturbance increases and resistant to invasive species increases (Chambers and others, 2014a). In many instances, treatments that reduce woody plants can have unintended consequences of increasing the establishment and spread of undesirable invasive plants where they were once minor component of communities (Chambers and others, 2014a). Understanding where sagebrush steppe ecosystems are sufficiently resilient to recover from woody plant reduction techniques without increasing invasive plants (Chambers and others, 2014b; Miller and others, 2014) is necessary when making decisions of where and what type of restoration techniques should be used to benefit management objectives.

Sagebrush steppe has undergone significant transformation influenced by multiple species invasions and land uses, but there are some consistent patterns of disturbance that are correlated to soils and elevation. At mid- to high elevations, tree cover has increased through fire suppression, climate change, and favorable conditions for establishment at the turn of the 20th century because of inappropriate livestock grazing practices (that is, too many animals, animals grazing for too long, or animals grazing during a season when grazing reduces plant growth or reproduction) (Miller and others, 2013). Grazing has also altered wildfire return intervals; some areas would have normally burned at intervals of less than 30 years before livestock grazing, but it has been 100 or more years since the last fire partially due to livestock use (Miller and Heyerdahl, 2008). 


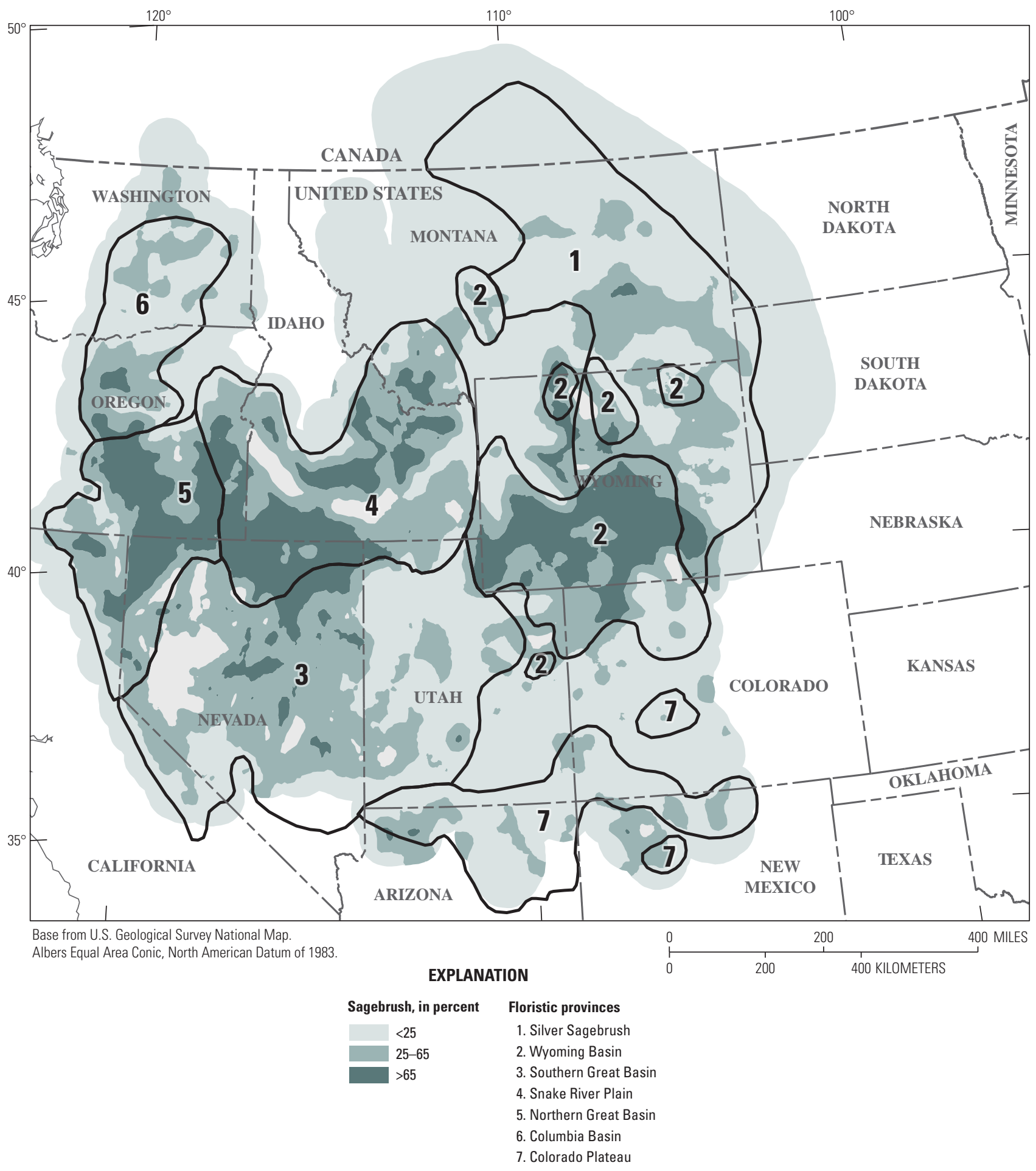

Figure 1. Percentage of landscape sagebrush cover in the seven floristic provinces included in the sagebrush steppe. The sage-grouse range is often divided into western (Columbia Basin, northern Great Basin, Snake River Plain, southern Great Basin) and eastern regions (Silver Sagebrush, Wyoming Basin, and Colorado Plateau) (from Miller and others, 2011). 
At low elevations, non-native annual grasses, such as cheatgrass (downy brome, Bromus tectorum), medusahead, (Taeniatherum caput-medusae), and red brome (Bromus rubens), were introduced into the Intermountain West during the late 1800s and have continued to spread throughout the region (Mack, 1981; Salo, 2005). The combination of land uses degrading native plant diversity and the characteristics that provide a competitive advantage toward these annual grasses have led to their dominance on many of the more arid lands in the region (Harris, 1967; Melgoza and others, 1990; Knapp, 1996). These annual grasses tended to fill vacant spaces among native perennial plants creating a continuous fuel for wildfires to burn and spread (Brooks and others, 2004), especially in areas where perennial herbs had been depleted by inappropriate livestock grazing (Reisner and others, 2013). Prior to the invasion of annual grasses, normal intervals between fires may have ranged from 50 to more than 300 years, whereas fire intervals of less than 10 years have become common with the inclusion of these annual grasses (Bukowski and Baker, 2013; Miller and others, 2013). Such frequent fires have led to the replacement of dominant native grasses and shrubs, including sagebrush, with non-native annual grasses. Once non-native annual grasses dominate, it is difficult for remaining native perennial plants to reproduce and establish sufficient numbers of individuals to successfully compete with these annual grasses (Miller and others, 2013).

Estimates vary but show the extent of the lands now dominated by annual grasses to be large (Miller and others, 2011) enough that costs of restoring native plant communities far exceed the logistics, personnel, and money available to restore native plant dominance across the region. Therefore, managers face difficult decisions and trade-offs regarding where, when, and how to implement restoration projects (Pyke, 2011; Hobbs and others, 2013). Historically, restoration of sagebrush steppe ecosystems have been largely limited to objectives associated with post-fire rehabilitation projects, but the heightened interest in sage-grouse conservation has increased importance of habitat restoration for the purpose of benefiting sage-grouse (Chambers and others, 2014a).

Managers making restoration decisions may benefit from a decision framework that first prioritizes the subset of lands that are high value for ecosystem services and likely to respond positively to management treatments. This framework expands on that developed by Pyke (2011) by incorporating new information on resilience and resistance of sagebrush steppe (Chambers and others, 2014b; Miller and others, 2014) and by expanding on other key concepts.

We initially provide a basic understanding of similarities and differences among sagebrush plant communities within the Western United States sagebrush steppe ecosystems, and their responses to fire and defoliation. Next, we identify how these communities may have varying levels of resilience to disturbance and resistance to invasive plants relative to soil temperature and moisture regimes. These two concepts aid in determining the need for restoration practices and their potential for success. Then we discuss soils and the ecological site concept that are critical for determining potential restoration plant species and how those plants will respond to disturbances. We then present a comparison of general restoration actions, some that may be implemented through changes in current management and those that may require direct revegetation to restore plant communities. Landscape restoration, discussed next, is a recent concept necessary for prioritizing potential restoration sites that would benefit landscape animals. These animals require additional landscape features besides just the establishment of plants for their habitat. Once a decision to restore a site is made, concepts regarding appropriate restoration methods should be considered, especially because some methods may be less effective in achieving restoration goals. We focus this discussion on the restoration needs of the sagegrouse. Lastly, we discuss the importance of effectiveness monitoring for adaptive management of future restoration treatments.

\section{Sagebrush Steppe Ecosystems}

The Great Basin (north and south), Columbia Basin, Snake River Plain, Colorado Plateau, and Wyoming Basin are dominated mostly by subspecies of big sagebrushbasin (Artemisia tridentata ssp. tridentata); mountain (A. t. ssp. vaseyana); and Wyoming (A. t. ssp. wyomingensis) (figs. 1 and 2). Low or short species of sagebrush (little sagebrush - A. arbuscula; black sagebrush-A. nova; silver sagebrush-A. cana; scabland or rigid or stiff sagebrush-A. rigida; sand sagebrush-A. filifolia; and threetip sagebrush-A. tripartita [fig. 2]) occur in topographic positions often associated with changes in 


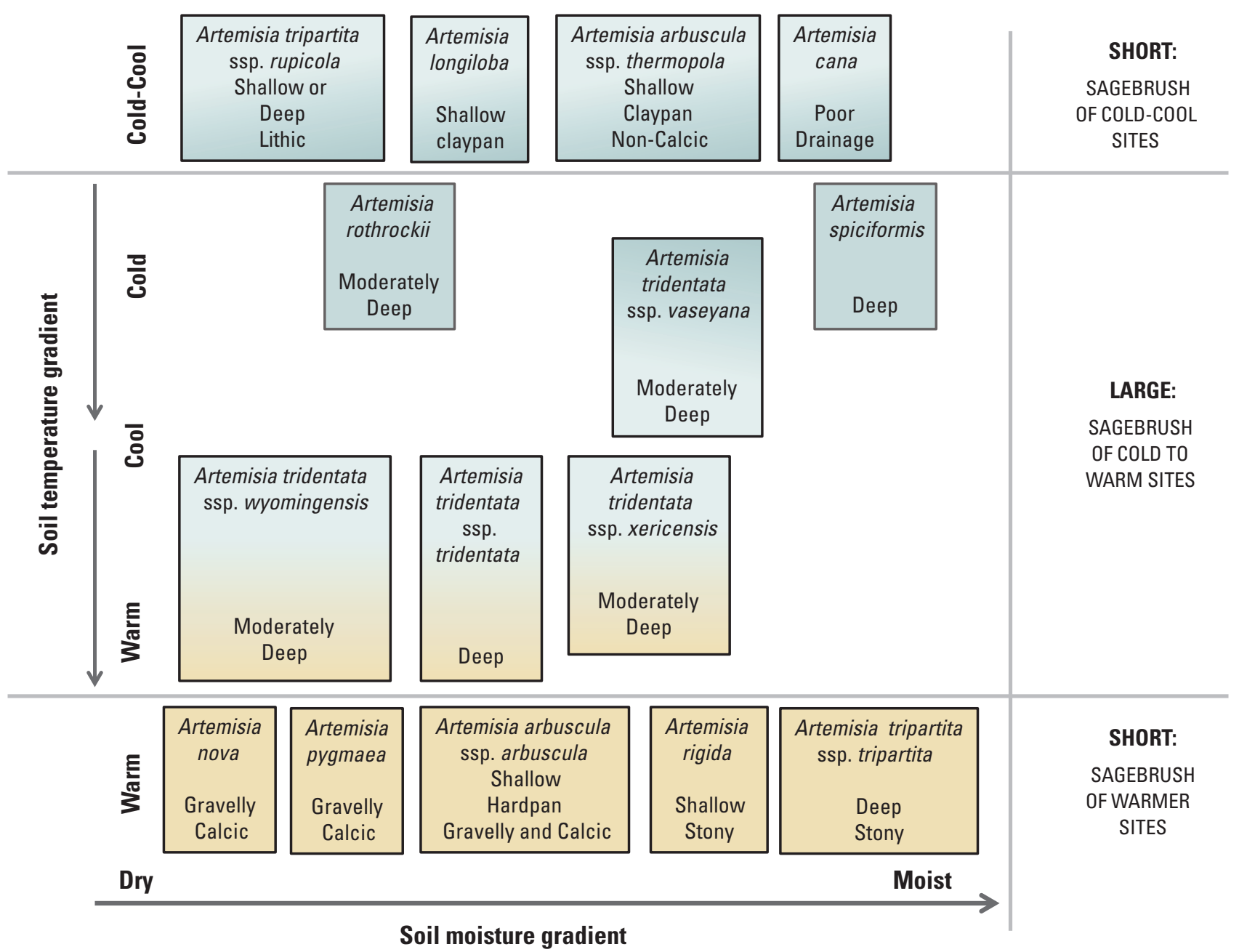

Figure 2. Sagebrush taxa in the Great Basin and Columbia Basin positioned along gradients of soil temperature and soil moisture. (Adapted from Robertson and others, 1966; McArthur, 1983; West, 1983; West and Young, 2000; Rosentreter, 2005; Shultz, 2009, 2012).

soil drainage or depth or changes in soil temperature and moisture regimes. As one moves farther east into the northwestern Great Plains and into the Silver Sagebrush province (fig. 1), silver sagebrush and prairie sagewort (also called fringed sagebrush $[$ A. frigida]) become more dominant along with Wyoming sagebrush, and sand sagebrush. In addition to the change in sagebrush species, individual plants of sagebrush tend to be less prominent and smaller in stature in this province than the same species in the western provinces. Grasses and forbs are more prominent such that sagebrush tends to be a codominant or a subdominant within this province as the climate and soils shift toward those of grasslands typical of the Great Plains.

\section{Herbaceous Component}

The herbaceous component of the sagebrush steppe ecosystems varies in the proportional amount of grasses to forbs. In general, cool and moist sites have more forbs and more herbaceous vegetation (Miller and others, 2011). Grasses across sagebrush steppe ecosystems can be divided into two categories based on their primary season of plant growth. This relates closely to the amount of summer moisture that is available for plant growth and to the air temperatures that exist when the moisture is available (Terri and Stowe, 1976; Ehleringer, 1978). Grasses in the northern Great Basin, Columbia Basin, and Snake River Plain, 
and central and western Wyoming are mostly cool season plants $\left(\mathrm{C}_{3}\right.$ photosynthetic pathways; see section, "CoolSeason and Warm-Season Plants"). Ecosystems farther south (southern Great Basin and Colorado Plateau) and east (western Great Plains) tend to be dominated by warm season plants $\left(\mathrm{C}_{4}\right.$ photosynthetic pathway; see section, "Cool-Season and Warm-Season Plants") because of the influence of summer monsoonal moisture providing regular precipitation in the summer in addition to winter moisture.

The reduced presence of warm season plants in the northern Great Basin and west to central Wyoming and through western Montana is a result of the regional dependence on winter precipitation, mostly snow, as the primary source of precipitation. Soil moisture recharge, if it occurs, happens from late autumn through early spring while temperatures are cool to cold, thus favoring plants that grow best during these times and that become dormant as the soil moisture is diminished and temperatures exceed levels at which these plants can grow (Ehleringer, 1978; Paruelo and Lauenroth, 1996). Plants farther south and east have the advantage of significant moisture that comes in winter when temperatures are cool and in late spring through summer as temperatures increase. This provides two growing seasons, one when cool season plants grow and one later in the summer when a different set of species, warm season plants, grow. This is a key difference among these regions and in restoration potential. It is important that both photosynthetic functional groups are represented in the vegetation mixture being restored if the location climate can support both.

The structure and composition of plant communities in the sagebrush steppe determine the potential for a site to provide desired habitat and forage for animals. Community descriptions are based on accounts in Shiflet (1994), West and Young (2000), and Knight and others (2014). Grasses in the western part of the sagebrush steppe (west of the Rocky Mountains) are dominated by species that form loose to dense tussocks or bunches. Most are mid-height, growing between 30 and $76 \mathrm{~cm}$ (12 and $30 \mathrm{in}$.) with more productive sites yielding taller grasses. One prominent and consistent short grass is Sandberg bluegrass (Poa secunda). Interspaces commonly occur among vascular plants, especially in more arid environments, and these interspaces generally are occupied by combinations of biological soil crusts (see section, "Biological Soil Crusts") that are visible (for example, lichens and mosses) or invisible (for example, cyanobacteria intermixed with soil particles). This invisible form appears to be bare soil and is difficult to distinguish from true bare soils that lack this form of biological soil crust.
East of the Rocky Mountains, grasses are often a mixture of bunch/tussocks and spreading forms with short (mat-forming; for example, blue grama [Bouteloua gracilis]) to long rhizomes (for example, western wheatgrass [Pascopyrum smithii]) or stolons (for example, buffalograss [Bouteloua dactyloides]) (Knight and others, 2014). Along with variable growth forms, there also are species considered as short grasses (for example, blue grama) and mid grasses (for example, western wheatgrass). The herbaceous component generally dominates or codominates in these plant communities. Vascular plants typically cover most of the soil surface in these ecosystems with little bare soil or biological soil crust.

\section{Cool-Season and Warm-Season Plants}

Cool-season plants are those that grow best at cool temperatures $\left(4-24^{\circ} \mathrm{C}\left[40-75^{\circ} \mathrm{F}\right]\right.$ with optimum growth at $\left.18-24^{\circ} \mathrm{C}\left[65-75^{\circ} \mathrm{F}\right]\right)$ depending on acclimation (Sage and Kubien, 2007). Cool-season plants generally dominate lands where the majority of the precipitation occurs as snow and moisture is available primarily when temperatures are cool or cold. As air temperatures exceed $24^{\circ} \mathrm{C}\left(75^{\circ} \mathrm{F}\right)$, plant growth of cool-season plants shuts down and these plants become dormant. Examples of cool-season grasses and forbs are bluebunch wheatgrass (Pseudoroegneria spicata), needle and thread (Hesperostipa comata), western wheatgrass (Pascopyrum smithii), tapertip hawksbeard (Crepis acuminata), and common yarrow (Achillea millefolium).

Warm-season plants grow best when temperatures are warm $\left(15-35^{\circ} \mathrm{C}\left[60-95^{\circ} \mathrm{F}\right]\right.$ with optimum growth at $\left.32-35^{\circ} \mathrm{C}\left[90-95^{\circ} \mathrm{F}\right]\right)$ depending on acclimation (Sage and Kubien, 2007). Warm-season plants occur on lands where precipitation occurs during the warm months of the summer. Rains fall as regular events during monsoonal or convective storms. Examples of warm-season plants are big galleta (Pleuraphis rigida), blue grama (Bouteloua gracilis), purple coneflower (Echinacea sp.), and Missouri goldenrod (Solidago missouriensis). 
In eastern and western sagebrush steppe ecosystems, forbs typically account for the greatest number of vascular plant species. However, as a group they provide significantly less cover in dry and warm locations $(<5$ percent cover in most Wyoming big sagebrush locations). Forbs may approach codominance, however, with grasses in cool, moist, and humid locations.

Common occurrences throughout sagebrush steppe ecosystems are stands that maintain high cover of sagebrush, but lack significant perennial herbaceous vegetation. These often grade between two extremes in composition - one where perennial herbaceous vegetation is sparse and mostly occurs under shrubs, and the other is similar regarding perennial herbaceous vegetation, but non-native annual grasses may codominate with shrubs. These communities with shrub dominance and little herbaceous perennial understory may lend to the perception of sagebrush being a weedy species (Whitson, 1996) and if left alone would ultimately dominate and crowd out the perennial herbaceous plants. These stands are often referred to as being "decadent." Alternatively, this scenario may have been created during times of inappropriate livestock grazing practices (Young and Sparks, 2002), where livestock removed native perennial grasses from interspaces, but perennial grasses under the sagebrush were left ungrazed or less frequently grazed because the shrub was unpalatable forage and the woody structure protected grasses beneath their canopies (Welch and Criddle, 2003; Reisner and others, 2013).

Regardless of the cause, the situation exists where there are insufficient understory perennial herbaceous plants for seed production and site recovery. Thinning of sagebrush stands to regain herbaceous cover and productivity is often considered as a management option, but before thinning occurs, land managers might determine if the community has sufficient perennial herbaceous plants to fill the void left by the sagebrush. Resilience of the community to disturbances and resistance to annual grass invasion are important factors for managers to determine. On warm, dry sites, resilience is low and recovery is unlikely to occur because weather conditions necessary for the combination of perennial grass seed production, followed by germination and establishment, are rare; whereas cheatgrass, if present, may fill voids left by thinning the shrubs and outcompeting the seedlings of perennial grasses for the limited resources for growth and survival (Chambers and others, 2007, 2014c).
Dominance among perennial and introduced annual species within an herbaceous community can vary on the scale of square centimeters to square meters within an otherwise dominated matrix of perennial bunchgrasses at the hectare scale, whereas on other sites, the reverse is true. Annual plants may dominate small areas of soil disturbances by rodents (Beatley, 1966), but they also are regulated by cover of perennial grasses. Chambers and others (2014a) studied a range of sites across the Intermountain West and provided evidence that when perennial grass foliar cover exceeded 20 percent before a disturbance (fire or mowing) then cheatgrass remained subordinate to perennial plants after disturbances. Understanding the cover of perennial grasses before disturbances, such as fire or livestock grazing, occur will aid manager decisions regarding potential restoration treatments.

\section{Biological Soil Crusts}

Biological soil crusts are an extremely important plant component for soil stability, nutrient cycling, and for resistance to annual grass invasions within dry parts of sagebrush steppe ecosystems where perennial plant cover is typically less than 100 percent (Rosentreter and Belnap, 2001; Reisner and others, 2013). These crusts consist of mosses, lichens, and cyanobacteria that adhere to or grow within the soil surface. They tend to occupy soil surfaces where light is available and where vascular plants do not cover them with vegetation or leaf litter. Biological soil crust species diversity and cover depend on soil type and environmental conditions (Rosentreter and Belnap, 2001). They are an important component of many arid and semiarid ecosystems because they stabilize exposed soil, mitigate soil disturbance from raindrop impacts, aid in infiltration, and influence soil nitrogen and carbon cycling. Biological soil crusts also appear to inhibit establishment of cheatgrass while facilitating establishment of many native plant species (Rosentreter and Belnap, 2001).

Biological soil crusts are highly susceptible to soil surface disturbances, plant litter (Belnap and Eldridge, 2001), and fire (Miller and others, 2013). Recent studies have shown negative relationships between biological soil crust cover and invasive annual grass dominance (Ponzetti and others, 2007; Peterson, 2013; Reisner and others, 2013). This is likely a combination of effects due to the degree of crust cover, and the density, cover, and gap size among perennial grasses in the community (Ponzetti and others, 2007; Reisner and others, 2013). 


\section{What is Cover?}

As with many terms, cover is in the eye of the beholder. Anytime someone speaks of sagebrush cover, we must be certain that we are interpreting the same type of cover as the speaker. Cover differs considerably if someone is speaking about landscape cover, ground cover, or hiding cover of sagebrush.

L andscape cover is a term often used in conjunction with broad regional or continental maps classified from remotely sensed data (for example, aerial photography or satellite imaging). Landscape cover is the proportion of an entire landscape area that is dominated by a common vegetation type or species. The average proportion of pixels dominated by the target species, such as sagebrush, is remapped onto the central pixel and then the window is moved one pixel and the process is repeated (rolling or moving window) until the full image is displayed as an average landscape cover projection of the target species. Landscape cover of sagebrush often has been measured by using such an approach. Examples include the Landfire Existing Vegetation Type (http://www.landfire.gov/NationalProductDescriptions21.php), Southwest ReGAP (http://earth.gis.usu.edu/swgap/landcover.html), or Sage-Stitch (http://sagemap.wr.usgs. gov/GISData.aspx). Increasingly, habitat maps derived from remote sensing are combined with local field expertise or surveys to delineate habitat classes used in management.

Ground cover is a general term used to estimate or measure the soil surface that is covered by plants, litter, rocks, biological soil crusts, or bare ground (exposed soil surface not covered by the other objects). For plants, ground cover is often used for determining the absolute cover of a plant species or a sitespecific relative cover (plant composition) of a species at the site. In general, ground cover for plants is the proportion of the ground surface of a local site $\left(<1 \mathrm{mi}^{2}\right.$ or 640 acres $)$ covered by a plant species or group of species. This can be estimated using numerous techniques, but each technique may vary in its estimate because of observer differences or the type of ground cover being measured and may create ambiguous results. Depending on the measurement technique, ground cover provides an estimate of either canopy cover or foliar cover of plants. The difference is described in the following foliar and canopy cover definitions through an explanation of a raindrop falling vertically to the ground.

Foliar cover is the ground area covered by plant parts (leaves, stems, and flowers) when the shape of each vegetation part is projected perpendicularly to the ground. Techniques for measuring foliar cover include point-intercept, line-point intercept, and line intercept (provided spaces between plant parts are not included). For foliar cover, if the raindrop hits a plant part before contacting the ground then it is contacting the foliar (including stems) portion of the plant. The proportion of drops that hit a plant species relative to other species or to the ground would provide an estimate of foliar plant cover.

Canopy cover includes the outline of the plant canopy and spaces among plant parts as the estimate of the canopy cover of the plant. Techniques that use this method are line intercept, where distances between plant parts of a defined amount are included in the cover measurement; or Daubenmire-type techniques, where a percent area of a polygon created by tracing the exterior of the canopy of the plant is estimated either visually or using various cover classes. For canopy cover, if the raindrop passes within the perimeter of the canopy of the plant without hitting a plant part then it would be considered part of the canopy cover. By definition, canopy cover measurements should exceed foliar cover of a plant.

Basal cover is the amount of surface area occupied by the stem of a plant that contacts the soil. It is an important variable for relating plant cover to the potential for surface-water erosion on the soil, especially sheet erosion, and it is less sensitive to annual weather variations than canopy or foliar cover; however, for bunchgrasses, basal cover is less sensitive to decreases in cover related to decreases in tiller numbers because both live and dead portions are often combined.

Hiding cover or horizontal cover is explained by rotating the raindrop 90 degrees and projecting it horizontally (parallel to the soil surface) into vegetation from a defined height and for a defined distance. This is often estimated using a cover pole or board with bands or grid cells of known size, where an observer determines how many grid cells or how much of each band, or both, are visible from the defined distance and height. 

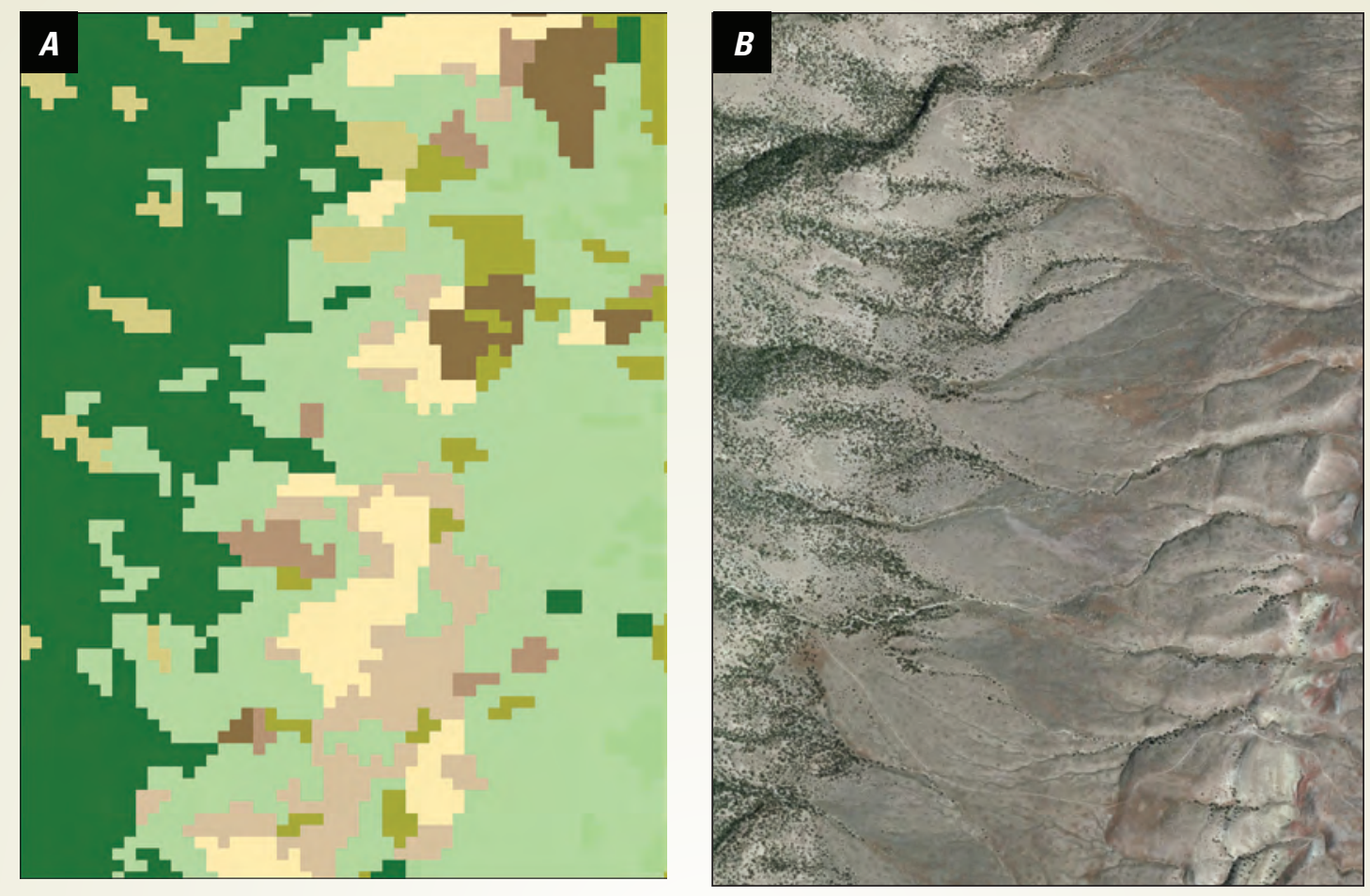

\section{EXPLANATION}

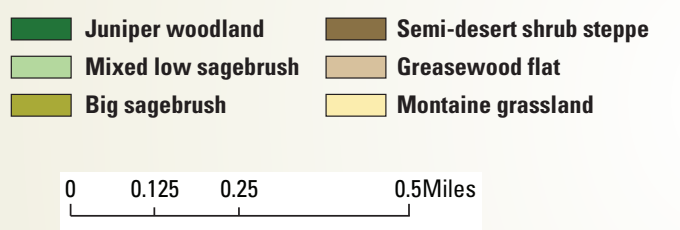

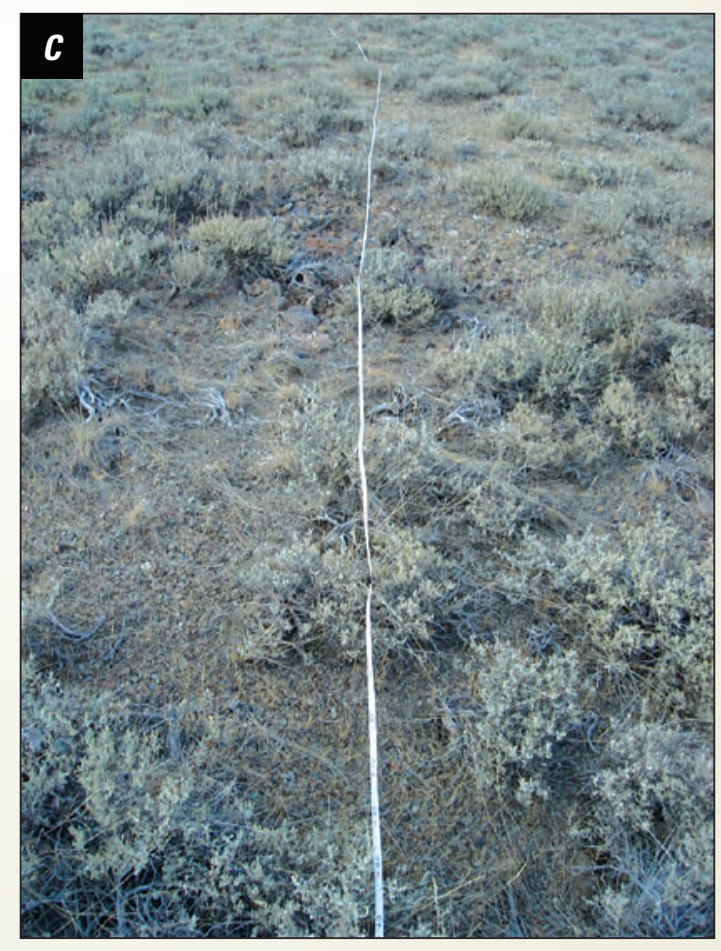

Landscape cover $(A)$, is a function of land cover types within a landscape or region. Because only dominant cover is classified from the image $(B)$, landscape cover is a spatial metric describing proportional area occupied by each community. Ground (or canopy) cover $(C)$ is estimated for individual sites and measures the percent of individual plants within the community. Source for landscape cover (B): Esri, DigitalGlobe, GeoEye, Earthstar Geographics, CNES/Airbus DS, USDA, USGS, AEX, Getmapping, Aerogrid, IGN, IGP, swisstopo, and the GIS User Community. Photograph (C) of ground sampling with transect tape through sagebrush taken by Steve Knick, U.S. Geological Survey, 2010. 


\section{Plant Responses to Fire and Defoliation}

Disturbances associated with fire and defoliation shape community dynamics and plant responses within sagebrush steppe ecosystems. Resprouting ability provides plants a mechanism to withstand disturbances that may remove aboveground parts of plants and to recover more quickly from disturbances. Those plants without resprouting mechanisms need to re-establish from seed (Pyke and others, 2010).

Common shrubs and forbs occurring within sagebrush steppe ecosystems have been grouped into their fire tolerance growth responses (Miller and others, 2013; table 1). Similar groupings of perennial grasses have been more problematic because grass tolerance to fire relates not only to the location of perennating buds, but also to the amount of litter and standing live and dead vegetation surrounding the plant and its effect on fuel around grass crowns. The more dense the fuel (fuel packing) around perennating buds, the more severe (intensity and duration) the fire and the more likely the grass will succumb to fire. In general, loosely rhizomatous grasses are more tolerant of fires than bunchgrasses. However, bunchgrasses with loosely packed stems and coarser leaves are more tolerant than those with dense stems and fine leaves. In addition, grasses growing in interspaces away from shrub canopies are more likely to survive fires than those growing under shrubs because woody plants tend to burn at higher temperatures for longer durations, increasing the potential for lethal temperatures.

Regionally, fires are most common and generally are larger in the northern and southern Great Basin, Snake River Plain, and Columbia Basin than in the Wyoming Basin and eastern Montana (Silver Sagebrush province) (Miller and others, 2011). Fire seasons vary among regions with the easternmost region being susceptible in late winter, whereas the western regions tend to burn in summer to early autumn. Eastern regions get more summer precipitation whereas western regions have practically none.

Defoliation, the removal of leaves and stems, removes photosynthetic and structural plant material that may affect the plant's ability to regrow or reproduce. Plant response to defoliation depends on the degree of tissue removal, season of the year, and resources available to the plant before and after defoliation.

Woody plants that have stems removed by browsing, mowing, or fire depend on existing perennating buds to form new leaves and stems. Big sagebrush is restricted in this regard to buds being located on stems that are less than 1 year old. If all wood produced in the last growing season was removed, then the plant will die immediately from a lack of buds for regrowth. Alternatively, species such as antelope bitterbrush (Purshia tridentata) are capable of stimulating bud development on branches of various ages (Bilbrough and Richards, 1993) making it more tolerant to defoliation or browsing.

In addition, reproduction of big sagebrush is restricted to branches extending from the upper buds on a newly produced branch (Bilbrough and Richards, 1993). Therefore, browsing of the upper buds on a sagebrush branch may result in fewer inflorescences being produced on browsed plants. Antelope bitterbrush, however, flowers from short shoots that may occur anywhere on previous year's growth, allowing it to tolerate some browsing without reductions in flowers (Bilbrough and Richards, 1993).

Perennial grasses in general are capable of withstanding some defoliation during the growing season without loss of ultimate biomass and reproduction, if defoliation occurs when plants can adequately respond with regrowth. Because perennial grasses in most of the semiarid Intermountain West are important for resilience of ecosystems to disturbances and for resistance against invasive annual grasses (Chambers and others, 2014c), the maintenance or increase in perennial grasses is often a goal of restoration. An increase in cover or density of perennial grasses is a common goal of restoration, but because establishing a resilient ecosystem also is important, we believe reproduction of perennial grasses should be included in the restoration goals. Although it was once thought that carbohydrate reserves were the important factor dictating regrowth after defoliation of grasses, we now understand that photosynthetic capacity is the principal influence of tiller regrowth, new tiller production, reproduction, grass survival, and vigor (Briske and others, 2011a). Defoliation during inflorescence development is especially harmful for seed production and tiller/ plant survival of bunchgrasses in the Great Basin (Briske and others, 2011a). In other regions (for example, Great Plains), however, adequate resources (for example, water or nutrients) are available to allow the production of new tillers and regrowth because of summer precipitation. This response will depend on the photosynthetic pathway (warm-season as opposed to cool-season plants) of the grazed species and its ability to photosynthesize after defoliation. Dormant season grazing usually has a less pronounced effect on plant survival and reproduction than defoliation from grazing during rapid growth because dormant season defoliation does not affect actively growing plant tissues. Light to moderate stocking levels that result in light to moderate grazing utilization $(<50$ percent $)$ during early growing season may be tolerated by grasses in the Intermountain West provided they allow floral production to occur (Briske and others, 2011a). 
Table 1. Tolerance levels for shrubs and perennial forbs to fire in the Great Basin and Columbia River Plateau provinces.

[Adapted from Miller and others, 2013. Shrubs: s, sprouter; ns, non-sprouter; ws, weak sprouter. Abbreviations: ssp., subspecies; sp., species not specified; spp., several species]

\begin{tabular}{|c|}
\hline SHRUBS \\
\hline Sagebrush steppe \\
\hline Tolerant \\
\hline
\end{tabular}

silver sagebrush

(Artemisia cana)(s)

subalpine big sagebrush

(Artemisia tridentata ssp. spiciformis)(s)

quaking aspen

(Populus tremuloides)(s)

yellow rabbitbrush

(Chrysothamnus viscidiflorus)(s)

wax currant

(Ribes cereum)(s)

desert gooseberry

(Ribes velutinum)(s)

Woods' rose

(Rosa woodsii)(s)

mountain snowberry

(Symphoricarpos oreophilus)(s)

horsebrush

(Tetradymia sp.)(s)

Saskatoon serviceberry

(Amelanchier alnifolia)(s)

Stansbury's cliffrose

(Purshia stansburiana)(s)

desert bitterbrush

(Purshia glandulosa)(s)

Nevada jointfir

(Ephedra nevadensis)(s)

\section{M oderately tolerant}

threetip sagebrush

(Artemisia tripartita)(s)

rubber rabbitbrush

(Ericameria nauseosa)(ws)

\section{Intolerant}

silver sagebrush

(Artemisia cana)(ns)

black sagebrush (Artemisia nova)(ns)

big sagebrush

(Artemisia tridentata)(ns)

curl-leaf mountain mahogany

(Cercocarpus ledifolius)(ws)

antelope bitterbrush

(Purshia tridentata)(ws)

Mexican cliffrose

(Purshia mexicana)(ws)

broom snakeweed

(Gutierrezia sarothrae)(ws)

\begin{tabular}{|l|}
\hline \multicolumn{1}{|c|}{ SHRUBS-Continued } \\
\hline Desert shrub \\
\hline Tolerant \\
\hline greasewood \\
(Sarcobatus vermiculatus)(s) \\
Torrey's saltbush \\
(Atriplex torreyi)(s) \\
Gardner's saltbush \\
(Atriplex gardneri)(s) \\
\hline Intolerant \\
\hline spiny hopsage \\
(Grayia spinosa)(ws) \\
bud sagebrush \\
(Picrothamnus desertorum)(ns) \\
shadscale saltbush \\
(Atriplex confertifolia)(ns) \\
fourwing saltbush \\
(Atriplex canescens)(ws) \\
winterfat \\
(Krascheninnikovia lanata)(ws) \\
\hline
\end{tabular}

\begin{tabular}{|c|}
\hline Buds below ground \\
\hline Tolerant \\
\hline
\end{tabular}

common yarrow

(Achillea millefolium)

agoseris

(Agoseris spp.)

onion

(Allium sp.)

aster

(Aster sp.)

milkvetch

(Astragalus sp.)

arrowleaf balsamroot

(Balsamorhiza sagittata)

mariposa lily

(Calochortus spp.)

hawksbeard

(Crepis spp.)

fleabane

(Erigeron spp.)

sticky purple geranium

(Geranium viscosissimum)

old man's whiskers

(Geum triflorum)

biscuitroot

(Lomatium spp.)

\section{FORBS-Continued}

Buds below ground-C ontinued

Tolerant- Continued

lupine

(Lupinus spp.)

bluebells

(Mertensia spp.)

woolly groundsel

(Packera cana)

beardtongue

(Penstemon spp.)

longleaf phlox

(Phlox longifolia)

lambstongue ragwort

(Senecio integerrimus)

largehead clover

(Trifolium macrocephalum)

deathcamas

(Zigadenus spp.)

mule-ears

(Wyethia amplexicaulis)

Buds above ground

Intolerant

pussytoes

(Antennaria spp.)

sandwort

(Arenaria spp.)

matted buckwheat

(Eriogonum caespitosum)

Douglas' buckwheat

(Eriogonum douglasii)

parsnipflower buckwheat

(Eriogonum heracleoides)

slender buckwheat

(Eriogonum microthecum)

rock buckwheat

(Eriogonum sphaerocephalum)

sulphur-flower buckwheat

(Eriogonum umbellatum)

spiny phlox

(Phlox hoodii) 
Perennial forbs have a similar tolerance to defoliation as perennial grasses. If the goal is to increase density and cover of perennial forbs then defoliation should be timed to promote both vegetative reproduction and seed production. The growth form of individual species may protect some perennial forbs from grazing during certain seasons and protect the individual plant from grazing-induced death, but seed production is less protected. The more decumbent (close to the soil) the forb's leaves, the less susceptible it will be to defoliation from large herbivores. This also depends on the type of grazing animal. Mouth and teeth morphology may allow some animals to defoliate plants close to the soil (for example, sheep) whereas others have greater difficulty (for example, cattle). Rosette-forming forbs, with leaves flat on the soil surface, are more protected from large herbivore grazing until reproduction, when bolting elevates inflorescences making them highly susceptible to removal. Forbs with upright growth forms are susceptible to defoliation throughout the nondormant phase of their life cycle. Grazing systems may be implemented to provide growing season rest to sustain growth and reproduction of desirable perennial herbaceous plants (Holechek and others, 2011). However, if the goal is to increase perennial forbs, then rest during the plant's reproduction is necessary to maximize seed production in those unpredictable years when environmental conditions are sufficient for seed production, germination, and establishment.

\section{Resilience to Disturbance and Resistance to Invasions by Annual Grasses in Sagebrush Steppe Ecosystems}

The need to understand complex interactions of multiple environmental variables and how those variables influence resilience to disturbance and resistance to invasion is of critical importance in the ability to effectively manage sagebrush steppe ecosystems. (Wisdom and Chambers, 2009; Brooks and Chambers, 2011; Chambers and others, 2013). In cold desert shrublands (Great Basin, Columbia Basin, Snake River Plain, and western parts of the Wyoming Basin), resilience of native ecosystems changes along climatic and topographic gradients. Wyoming big sagebrush, mountain big sagebrush, and mountain brush communities occur at progressively higher elevations (fig. 3, West and Young, 2000). Pinyon pine (Pinus monophylla and P. edulis) and junipers (Juniperus occidentalis, and J. osteosperma) are typically associated with mountain big sagebrush types, but can occur with relatively cool and moist Wyoming big sagebrush types and warm and moist mountain brush types (Miller and others, 2013). Resilience to disturbance, such as wildfires, increases along these elevation gradients (fig. 4A) (Condon

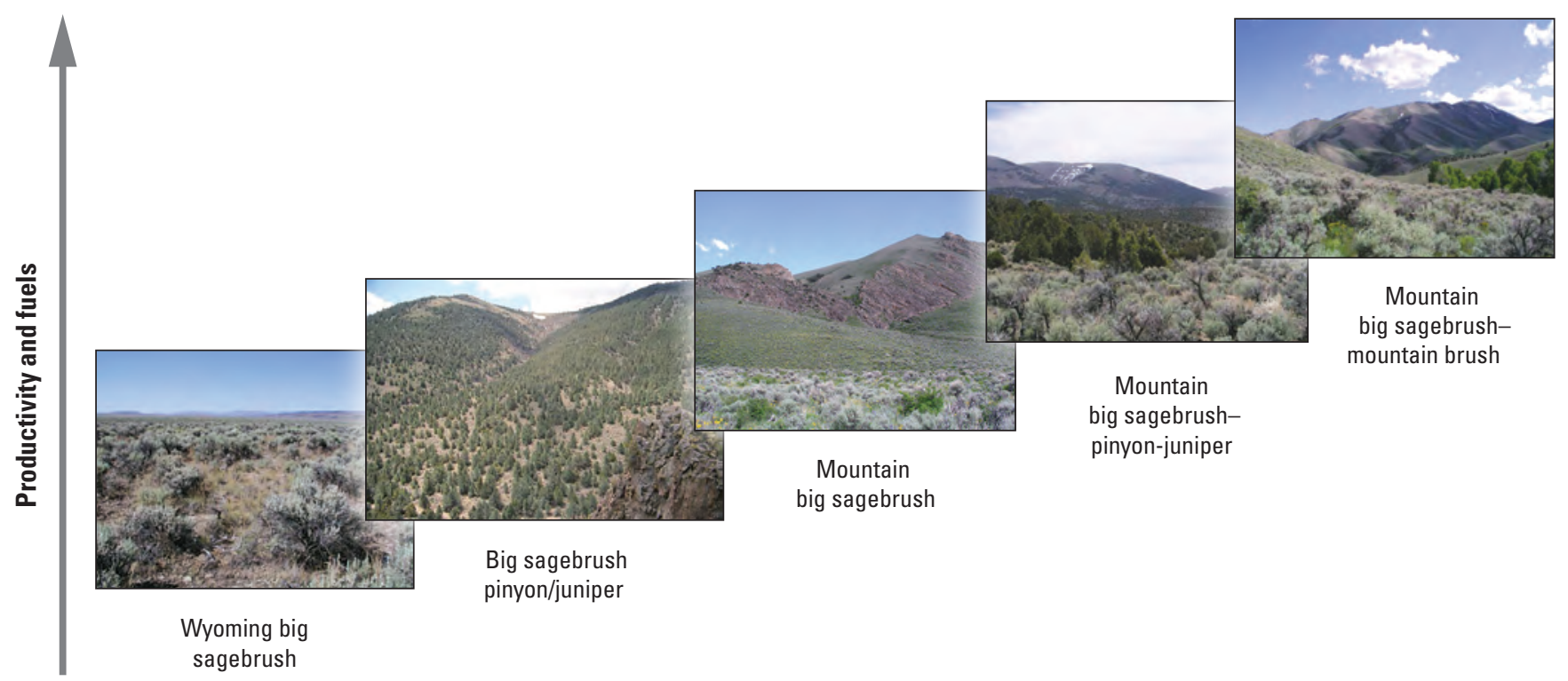

Warm-dry

Soil temperature and moisture

Figure 3. Relationship between soil temperature-moisture regimes and productivity or fuel loads with example plant communities (photographs) distributed along the gradient. (Modified from Chambers and others, 2014b.) (Photographs taken by Jeanne Chambers, U.S. Forest Service, Rocky Mountain Research Station.) 

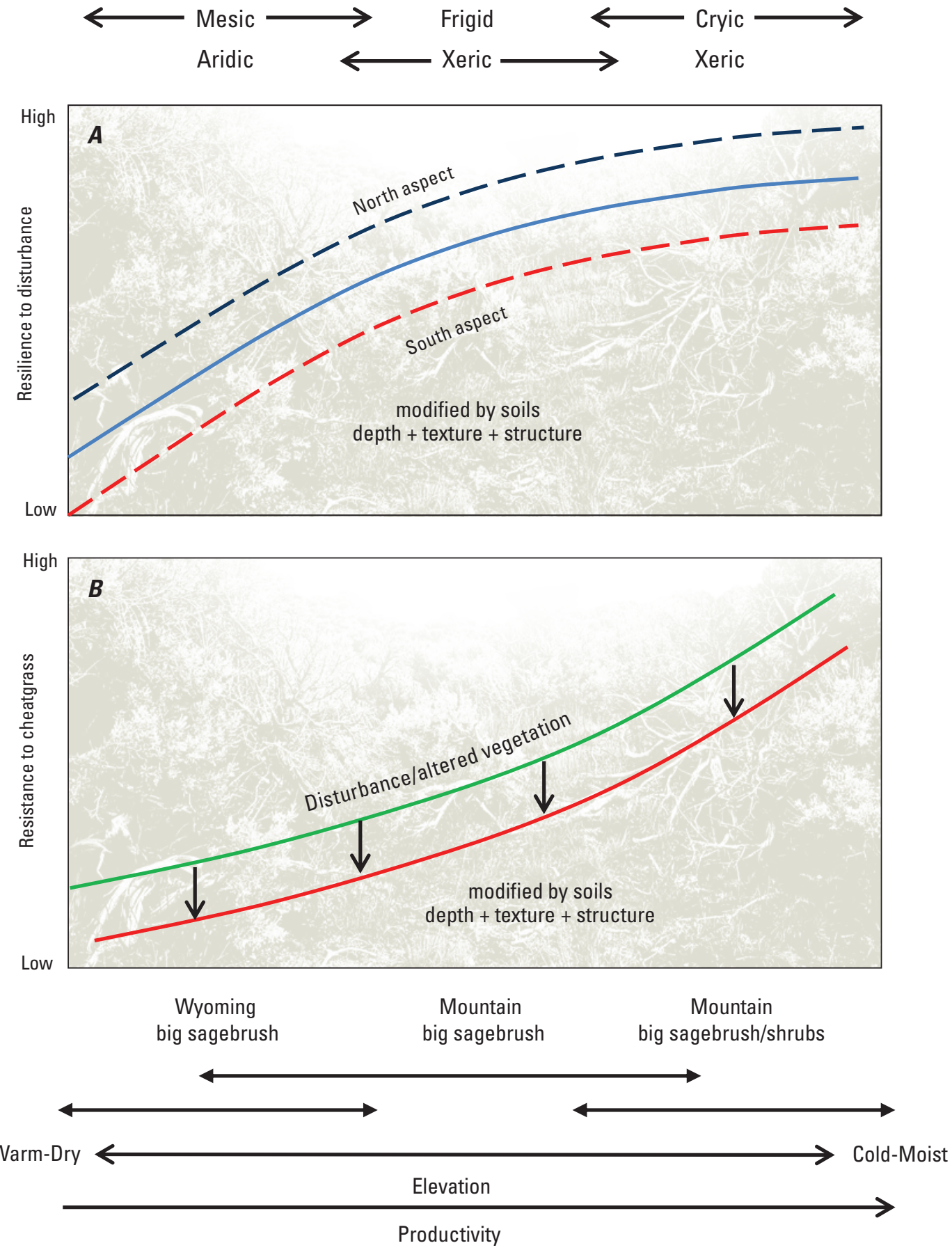

Figure 4. Resilience to disturbance $(A)$ and resistance to cheatgrass $(B)$ over a typical temperature/ precipitation gradient in the Great Basin. Dominant ecological sites occur along a continuum that includes Wyoming big sagebrush on mesic-aridic sites, mountain big sagebrush on frigid-xeric sites, and mountain big sagebrush and root-sprouting shrubs on cryic-xeric sites. Resilience increases along the temperature/ precipitation gradient and is influenced strongly by site characteristics like aspect. Resistance also increases along the temperature/precipitation gradient and is affected by disturbances and management treatments that alter vegetation structure and composition and increase resource availability. (Modified from Chambers and others, 2013, 2014b.) 
and others, 2011; Davies and others, 2012; Chambers and others, 2013, 2014b). As elevation and precipitation increase and temperatures cool, greater soil development and plant productivity result in greater resources and more favorable environmental conditions for plant growth, reproduction, and potential fuel loads (Alexander and others, 1993; Dahlgren and others, 1997; Miller and others, 2013). In addition, these relationships are observed at local plant community scales where aspect, slope, and topographic position affect solar radiation, heat load, erosion processes, and soil water availability for plant growth (Condon and others, 2011; Johnson and Miller, 2006).

Resistance to invasive annual grasses depends on environmental factors and ecosystem attributes and is a function of a species' (1) physiological and life history requirements for establishment, growth, and reproduction; (2) interactions with the native perennial plant community, such as competition or facilitation; and (3) tolerance to or avoidance of herbivory. In cold desert shrublands of the Intermountain West, resistance is strongly influenced by soil temperature and precipitation regimes (Meyer and others, 2001; Chambers and others, 2007).

The occurrence and persistence of invasive annual grasses in sagebrush habitats are strongly influenced by interactions with the native perennial plant community (fig. 4B). Cheatgrass, a facultative winter annual, can germinate from early autumn through spring, can exhibit root elongation at low soil temperatures, and has higher nutrient uptake and growth rates than native species (Mack and Pyke, 1983; Knapp, 1996; James and others, 2008). Seedlings of native perennial species are generally poor competitors with cheatgrass, but adults of native perennial grasses and forbs, especially those with similar growth forms and phenologies, can be highly effective competitors (Booth and others, 2003; Chambers and others, 2007). Disturbances or management treatments that reduce abundance of perennial plants and increase distances among perennial plants can increase soil resource availability and significantly increase growth and reproduction of cheatgrass given suitable environmental conditions (Chambers and others, 2007; Reisner and others, 2013; Roundy and others, 2014).

Germination, growth, and reproduction of cheatgrass are limited at low elevations by salinity/alkalinity and by frequent low and sporadic precipitation years. At high elevations, cheatgrass is constrained by low soil temperatures. Cheatgrass appears to have optimal growth and production at mid-elevations under relatively moderate to warm temperatures and water availabilities (fig. 4B; Meyer and others, 2001; Chambers and others, 2007). Slope, aspect, and soil characteristics modify soil temperature and water availability, and influence resistance to cheatgrass at landscape to plant community scales (Chambers and others, 2007; Condon and others, 2011; Reisner and others, 2013). Genetic variation in cheatgrass resulting from multiple introductions from a variety of old world locations results in traits that increase survival and persistence in populations from a range of environments and is likely contributing to the recent range expansion of this highly inbreeding species into what once were marginal habitats (Ramakrishnan and others, 2006; Merrill and others, 2012).

The type, characteristics, and historical range of variability of environmental stress and disturbance strongly influence resilience and resistance (Jackson, 2006). Disturbances like inappropriate grazing and more frequent or severe fires are outside of the historical range of variability and can reduce the resilience of sagebrush shrublands. Reduced resilience also can result from changes in environmental factors such as temperature regimes, abiotic attributes such as water and nutrient availability, and biotic attributes such as vegetation structure, composition, and productivity (Chapin and others, 1996). Resistance to an invasive species can change when changes in abiotic and biotic attributes result in increased resource availability or altered habitat suitability that influence the invasive plant's ability to establish and persist or to compete with native species. Progressive losses of resilience and resistance can result in communities crossing abiotic and biotic thresholds to an alternative successional state and the inability of the system to recover to the original reference state (Beisner and others, 2003; Seastedt and others, 2008).

Interactions among disturbances and stressors may have cumulative effects on the sagebrush communities (Chambers and others, 2013). Climate change already may be shifting fire regimes outside of the historical range of variability (that is, longer wildfire seasons with more frequent and longer duration wildfires; Westerling and others, 2006). Sagebrush steppe ecosystems generally have low productivity and the largest areas burned often occur a year or two after warm and wet winters and springs because these conditions result in high fine fuel loads (Knapp, 1995; Littell and others, 2009). Thus, annual grass fire cycles may be promoted by warm and wet winters and springs followed by a subsequent increase in establishment and growth of invasive winter annual grasses. These annual grass fire cycles may be exacerbated by the combination of global change factors, such as rising carbon dioxide and nitrogen deposition with increases in human activities that result in soil surface disturbance and invasion corridors (Bradley, 2010). Low elevation areas with low initial productivity are likely more prone than high elevation areas with high productivity to invasions resulting in alternative stable states dominated by invasive species. 
In general, sagebrush steppe ecosystems tend to be more resilient in the Silver Sagebrush province in the northeastern part of the range than other provinces (fig. 1). Managers should remain cautious, however, because cheatgrass and other annual brome species are having increased effects in the Great Plains and Rocky Mountains (Bradford and Lauenroth, 2006; Bradley, 2009). In addition, less is known about how other invasive grasses in these regions such as field brome (Bromus arvensis formerly Japanese brome, B. japonicus) are impacting sagebrush communities (White and Currie, 1983; Ogle and others, 2003). Soil disturbance in these plant communities may allow invasive grasses to establish and compete with desirable perennial seedlings. Once established, invasive grasses can retard recovery of perennial plants after disturbances such as fire (Romo and Eddleman, 1987; Whisenant, 1990). Field brome can develop monoculture stands that are similar to cheatgrass or may dominate the understory community. Yet field brome is not known to change the fire regime, possibly because this annual grass dies when the region changes into a period of more predictable summer moisture that may increase fuel moisture levels and limit large fires.

A field guide for determining resilience to disturbance, resistance to invasive annual grasses, and post-treatment succession was developed recently (Miller and others, 2014). This field guide uses characteristics of the ecological site, current vegetation, disturbance history, treatment information (type, timing, and severity), post-treatment weather, and post-treatment management (especially grazing), to inform management and restoration approaches and to aid in monitoring and adaptive management. Through answering questions, managers can evaluate the site's resilience to disturbance and resistance to invasive species, predict potential successional pathways, and select the most appropriate treatment (active as opposed to passive approaches), including an estimate of the probability of seeding success.

\section{Soils and Ecological Site Descriptions-Roles in Restoration}

Soils and climate are the basic foundations on which plant communities are based. We will use concepts and descriptions relating to soils and plant communities to categorize lands as more or less resilient to disturbances and resistant to the invasions of non-native annual grasses. These concepts also will aid in selecting those lands that will likely require restoration and the types of restoration techniques that will likely restore and sustain sagebrush steppe ecosystems.

\section{Soil Moisture and Soil Temperature Regimes as Indicators of Resilience and Resistance}

The potential for sagebrush steppe ecosystems to be resilient to fire and resistant to the invasion of non-native annual grasses depends on the environmental conditions of the land area. Resilience and resistance within sagebrush steppe ecosystems are greatest on lands with cool to cold (frigid to cryic) soil temperature regimes and relatively moist (xeric to ustic) soil moisture regimes, whereas the lowest potential resilience and resistance occurs with warm (mesic) soil temperatures and relatively dry (aridic) soil moisture regimes (Chambers and others, 2013, 2014a). Locations with high soil moisture also will have high productivity contributing to their increased resilience (Chambers and others, 2013), whereas annual grass growth and reproduction is limited by cold soil temperatures contributing to increased resistance on such locations (Pierson and Mack, 1990; Chambers and others, 2007). The precipitation season also is important in describing ecosystem resistance because invasive annual grasses that are problematic in changing fire regimes in sagebrush steppe ecosystems are particularly well-adapted to Mediterranean-type climates with cool (but not cold) and wet winters, and warm and dry summers (Bradford and Lauenroth, 2006; Bradley, 2009). In addition, areas that receive consistent and predictable summer precipitation (ustic soil moisture regimes) are dominated by a combination of cool-season and warm-season grasses (Sala and others, 1997), potentially providing a more competitive environment and resulting in increased resistance to annual grass invasion and spread (Bradford and Lauenroth, 2006; Bradley, 2009).

Sagebrush steppe ecosystems in the Great Plains, Wyoming Basin, Colorado Plateau, and cool to cold or moist sites throughout the sagebrush biome are considered to have moderate to high resilience and resistance as a result of their soil temperature and moisture regimes (fig. 5; table 2; Chambers and others, 2014c). Sagebrush habitats across the Great Plains are particularly unique from a range-wide perspective because soils are predominantly ustic, or bordering on ustic, as a result of summer precipitation and this soil moisture regime increases the inherent resilience and resistance of this portion of the biome (Bradford and Lauenroth, 2006). Alternatively, parts of the southern Great Basin, and much of the Snake River Plains, northern Great Basin, and Columbia Basin have warm and dry soils that support vegetation communities with moderately low to low resilience and resistance (fig. 5; table 2; Chambers and others, 2014c). 


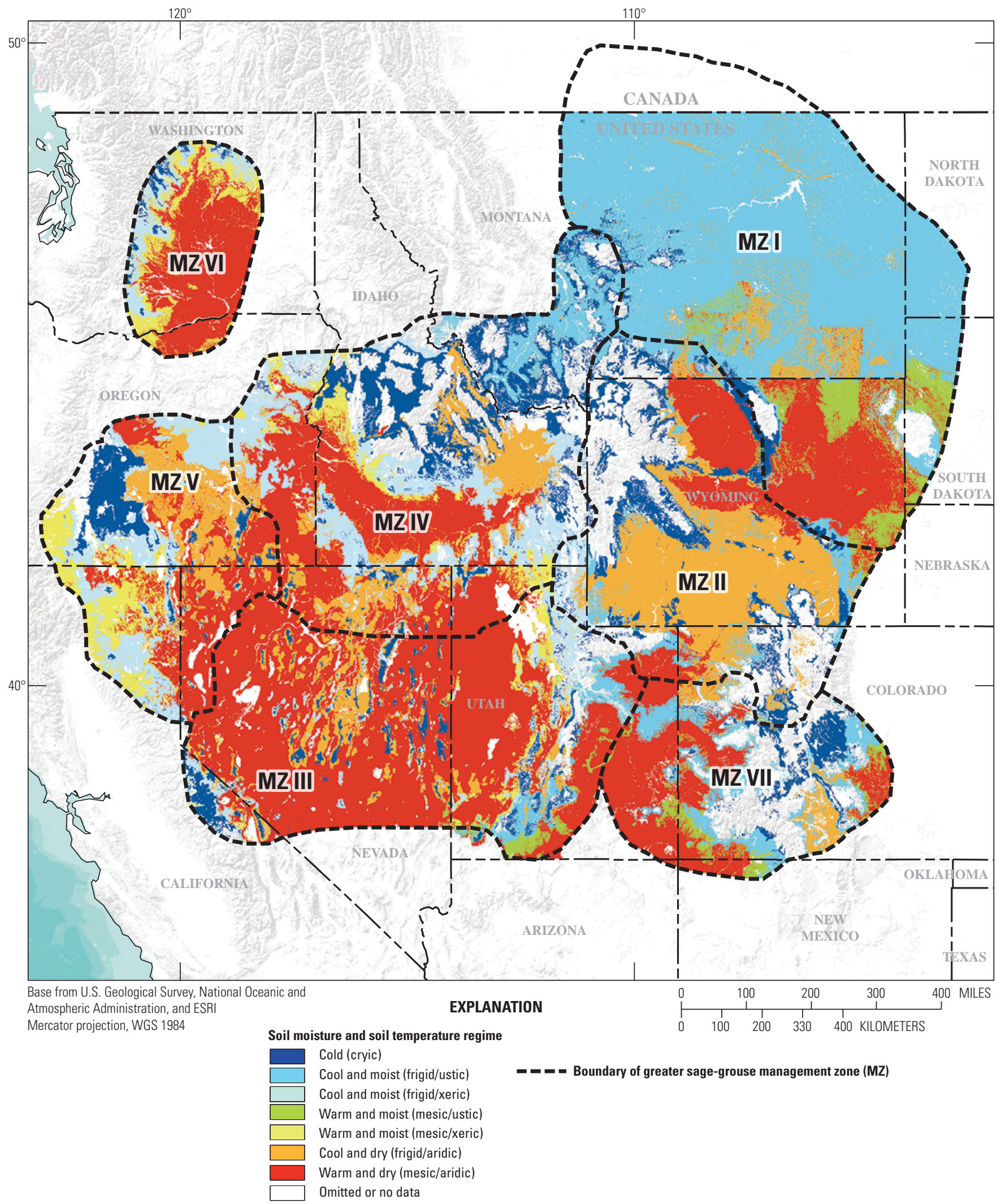

Figure 5. Soil moisture and soil temperature regimes that characterize the greater sage-grouse management zones. Management zones (MZ) are roughly equal to the floristic provinces shown in figure 1. MZ I approximates Silver Sagebrush, MZ II approximates Wyoming Basin, MZ III approximates southern Great Basin, MZ IV approximates Snake River Plain, MZ V approximates northern Great Basin, MZ VI approximates Columbia Basin, and the MZ VII approximates Colorado Plateau (from Chambers and others, 2014c). 
Table 2. Major sagebrush ecological types for California, Idaho, Nevada, Oregon, Utah, and Washington.

[Sage-grouse management zones III, IV, V, and VI see figure 6 based on soil temperature and soil moisture regimes, typical precipitation and shrubs, and resilience to disturbance and resistance to invasive annual grasses (modified from Chambers and others, 2014c; Miller and others, 2014). The Ustic soil moisture class is not included because data on resilience and resistance responses are lacking. cm, centimeters; in., inch]

\begin{tabular}{|c|c|c|}
\hline Ecological type & Characteristics & Resilience and resistance \\
\hline $\begin{array}{l}\text { Cold and moist } \\
\text { (cryic/xeric) }\end{array}$ & $\begin{array}{l}\text { Typical precipitation: } 35 \mathrm{~cm}+(14 \text { in. }+) \\
\text { Typical shrubs: Mountain big sagebrush, } \\
\text { snowfield sagebrush, snowberry, } \\
\text { serviceberry, silver sagebrush, and/or low } \\
\text { sagebrushes }\end{array}$ & $\begin{array}{l}\text { Resilience-Moderately high. Precipitation and } \\
\text { productivity are generally high. Short growing seasons } \\
\text { can decrease resilience on coldest sites. } \\
\text { Resistance-High. Low climate suitability to invasive } \\
\text { annual grasses. }\end{array}$ \\
\hline $\begin{array}{l}\text { Cool and moist } \\
\text { (frigid/xeric) }\end{array}$ & $\begin{array}{l}\text { Typical precipitation: } 30-55 \mathrm{~cm}(12-22 \text { in.) } \\
\text { Typical shrubs: Mountain big } \\
\text { sagebrush, antelope bitterbrush, } \\
\text { snowberry, and/or low sagebrushes } \\
\text { pinyon pine and juniper potential in } \\
\text { some areas }\end{array}$ & $\begin{array}{l}\text { Resilience_-M oderately high. Precipitation and } \\
\text { productivity are generally high. Decreases in site } \\
\text { productivity, herbaceous perennial species, and } \\
\text { ecological conditions can decrease resilience. } \\
\text { Resistance - M oderate. Climate suitability to } \\
\text { invasive annual grasses is moderate, but increase as soil } \\
\text { temperatures increase. }\end{array}$ \\
\hline $\begin{array}{l}\text { Warm and moist } \\
\text { (mesic/xeric) }\end{array}$ & $\begin{array}{l}\text { Typical precipitation: } 30-40 \mathrm{~cm} \text { (12-16 in.) } \\
\text { Typical shrubs: Wyoming big sagebrush, } \\
\text { Mountain big sagebrush, Bonneville big } \\
\text { sagebrush, and/or low sagebrushes } \\
\text { pinyon pine and juniper potential in } \\
\text { some areas }\end{array}$ & $\begin{array}{l}\text { Resilience-M oderate. Precipitation and productivity } \\
\text { are moderately high. Decreases in site productivity, } \\
\text { herbaceous perennial species, and ecological conditions } \\
\text { can decrease resilience. } \\
\text { Resistance - M oderately low. Climate suitability to } \\
\text { invasive annual grasses is moderately low, but increases } \\
\text { as soil temperatures increase. }\end{array}$ \\
\hline $\begin{array}{l}\text { Cool and dry } \\
\text { (frigid/aridic) }\end{array}$ & $\begin{array}{l}\text { Typical precipitation: } 15-30 \mathrm{~cm} \text { (6-12 in.) } \\
\text { Typical shrubs: Wyoming big sagebrush, } \\
\text { black sagebrush, and/or low sagebrushes }\end{array}$ & $\begin{array}{l}\text { Resilience - L ow. Effective precipitation limits site } \\
\text { productivity. Decreases in site productivity, herbaceous } \\
\text { perennial species, and ecological conditions further } \\
\text { decrease resilience. } \\
\text { Resistance-M oderate. Climate suitability to invasive annual } \\
\text { grasses is moderate, but increases as soil temperatures increase. }\end{array}$ \\
\hline $\begin{array}{l}\text { Warm and dry } \\
\text { (mesic/aridic, } \\
\text { bordering on xeric) }\end{array}$ & $\begin{array}{l}\text { Typical precipitation: } 20-30 \mathrm{~cm} \text { (8-12 in.) } \\
\text { Typical shrubs: Wyoming big sagebrush, } \\
\text { black sagebrush, and/or low sagebrushes }\end{array}$ & $\begin{array}{l}\text { Resilience - L ow. Effective precipitation limits site } \\
\text { productivity. Decreases in site productivity, herbaceous } \\
\text { perennial species, and ecological conditions further } \\
\text { decrease resilience. Cool season grasses susceptibility to grazing } \\
\text { and fire, along with hot dry summer fire conditions, promote } \\
\text { cheatgrass establishment and persistence. } \\
\text { Resistance-L ow. High climate suitability to cheatgrass } \\
\text { and other invasive annual grasses. Resistance } \\
\text { generally decreases as soil temperature increases, } \\
\text { but establishment and growth are highly dependent on } \\
\text { precipitation. }\end{array}$ \\
\hline
\end{tabular}


Soil Maps and Descriptions.-Soils are described and mapped at varying degrees of detail using soil map units (for example, Soil Survey Geographic Database [SSURGO; http://www.nrcs.usda.gov/wps/portal/nrcs/ detail/soils/survey/geo/?cid=nrcs142p2_053627] and the Digital General Soils Map [STATSGO2; http:// www.nrcs.usda.gov/wps/portal/nrcs/detail/soils/survey/ geo/?cid=nrcs142p2_053629]). Soil map units are areas dominated by one or more soil map unit components. Major components occupy greater than 15 percent of the map unit and are listed in the map unit description with the proportion of the map unit in which each component is estimated to occur.

Many management offices (Natural Resources Conservation Service [NRCS], Bureau of Land Management [BLM] or U.S. Forest Service [USFS]) may already have soil map and soil survey information available on their geographic information systems (GIS). In some cases, soil maps and their associated soil surveys may not be officially released, but are in draft form and not available on the web. Contact local or State soil scientists with these agencies to determine if draft maps are available for use.

E cological Sites and E cological Site Descriptions.-

The ecological site concept used by the NRCS and the BLM and being developed on U.S. Forest Service USFS lands (Caudle and others, 2013) aggregates areas with similar soils and climate that will support similar amounts and types of vegetation. Ecological site descriptions (ESDs) illustrate environmental characteristics and soils that can support a set of dynamic plant communities. These descriptions include information on disturbances that influence vegetation changes on these sites (Caudle and others, 2013).

Each soil map unit component will correlate to a specific ecological site. An ecological site is defined as a distinctive kind of land based on recurring soil, landform, geological, and climate characteristics that differs from other kinds of land in its ability to produce distinctive kinds and amounts of vegetation and in its ability to respond similarly to management actions and natural disturbances (Caudle and others, 2013). The relationship between soil components and ecological sites is many to one, meaning there may be many soil map unit components that will correlate to and support a single ecological site. This is because a plant community associated with an ecological site is influenced by a combination of soils, slope, aspect, elevation, and climate. As a rudimentary example, a sandy soil has a lower water holding capacity relative to a loamy soil with the same depth, but they may both support the same vegetation if the sandy soil has more effective moisture because of a north-facing slope with less evaporation than a loamy soil on a south-facing slope.

Each ecological site has a written description that includes physiographic, soil, climate, water influences, and plant communities with their natural disturbances. The plant communities and disturbances section of the site description provides information on the successional communities that can be expected and on the ability of the ecological site to resist non-native plant invasion and to be resilient to disturbances. The plant community information provides managers with a list of dominant plants that typically occur on the ecological site and the proportional relationship (that is, composition or relative biomass and cover) depending on disturbances and the time since disturbances. The ecological site description is an excellent resource that identifies potential plants for restoration projects. Published ecological site descriptions can be accessed at https://esis.sc.egov.usda.gov/Welcome/ pgReportLocation.aspx?type=ESD (accessed April 6, 2015). If ecological site descriptions are not available, contact your State Rangeland Management Specialist for the U.S. Department of Agriculture NRCS.

Successional States and Plant Community Phases in E cological Sites.-Included in each ecological site description is an explanation of the successional dynamics of plant communities that may occur on the ecological site. These are displayed as conceptual models using State and Transition successional dynamics (fig. 6) where plant community phases are expressed by a change in dominance among species within communities and where these dominance changes can fluctuate among each other within relatively stable states. The successional state that contains plant community phases, where ecological attributes (soil and site stability, hydrologic function, and biotic integrity) are functioning near optimum levels under a natural disturbance regime, is referred to as the reference state or sometimes referred to as the Historic Natural Plant Communities in ESDs. However, physical, hydrological, or biological changes within the land unit can result in shifts to alternative stable states in which resilience of the ecosystem to recover to its original reference state is unlikely. Shifts to alternative stable states may require active rather than passive restoration to achieve the desired plant community if that desired community was in the reference state. 


\section{Accessing and Reading Soil Maps and Their Descriptions}

Soil maps are available as geographic information systems files or can be accessed online through the Natural Resources Conservation Service Web Soil Survey application (http://websoilsurvey.nrcs.usda.gov). Soil maps consist of polygons overlain on aerial images of land and are meant to depict the approximate locations of soils on the landscape. Each polygon is a delineation of a map unit and is given a number-letter code that relates to the unique soil map unit estimated to be at that location. A set of delineations with the same code is called a soil map unit and the code is the soil map unit code. The soil map unit is the basic element of the soil map.

Each soil map unit may consist of one or more soils. Soils that consist of greater than 15 percent of the area in a soil map unit are called soil map unit components. They represent the soil series and may additionally contain a description of the landscape (slope or aspect) in which the component is located. Each soil map unit component will carry an estimate of the proportion of land area that it represents in that specific soil map unit.

The remaining 15 percent of the area is represented by minor soil map unit components often referred to as inclusions. These soils may exist within the listed soil map unit, but the probability of occurrence is low.

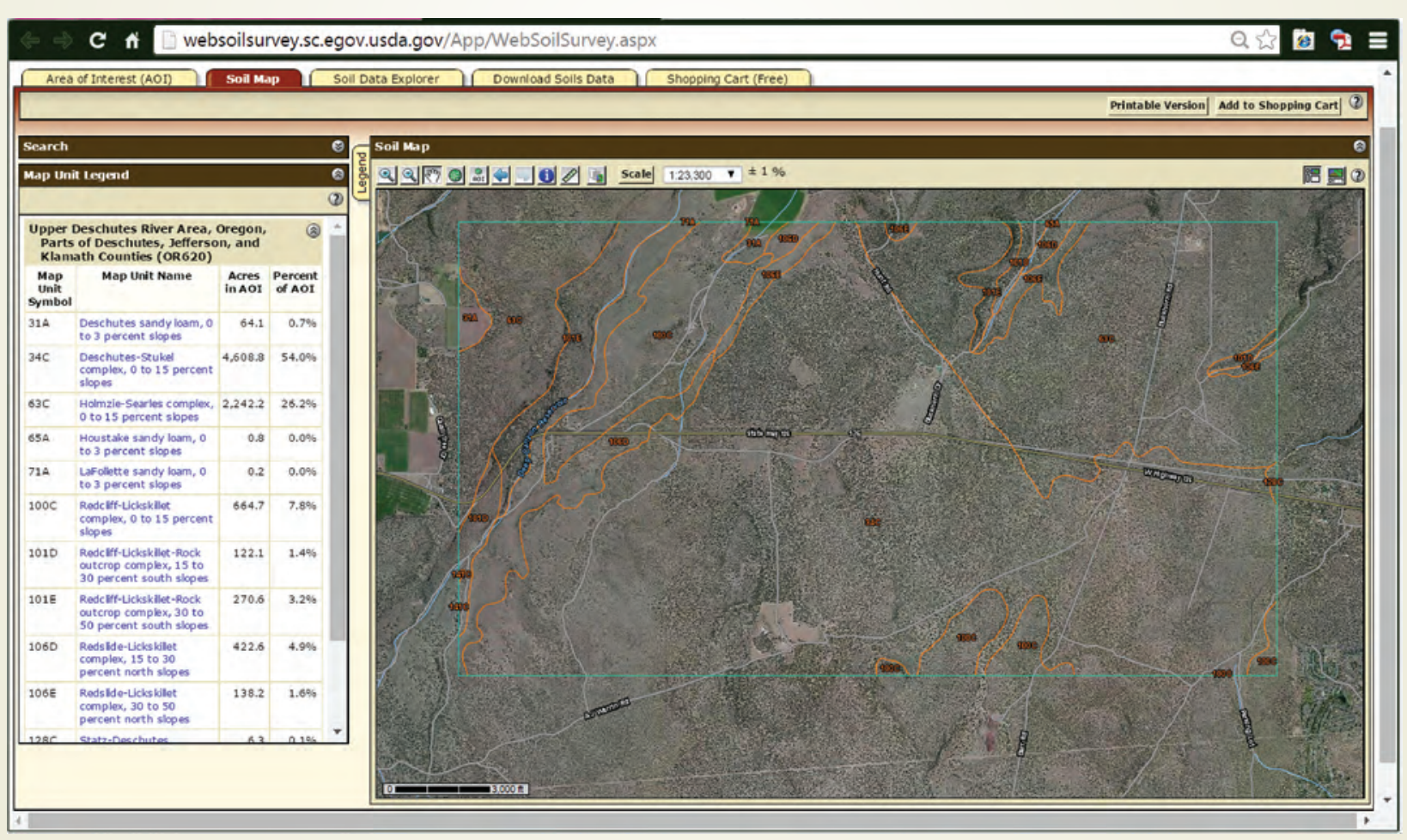

Screenshot showing a Web Soil Survey soil map and detailed descriptions of major soil components in the selected area of interest. 


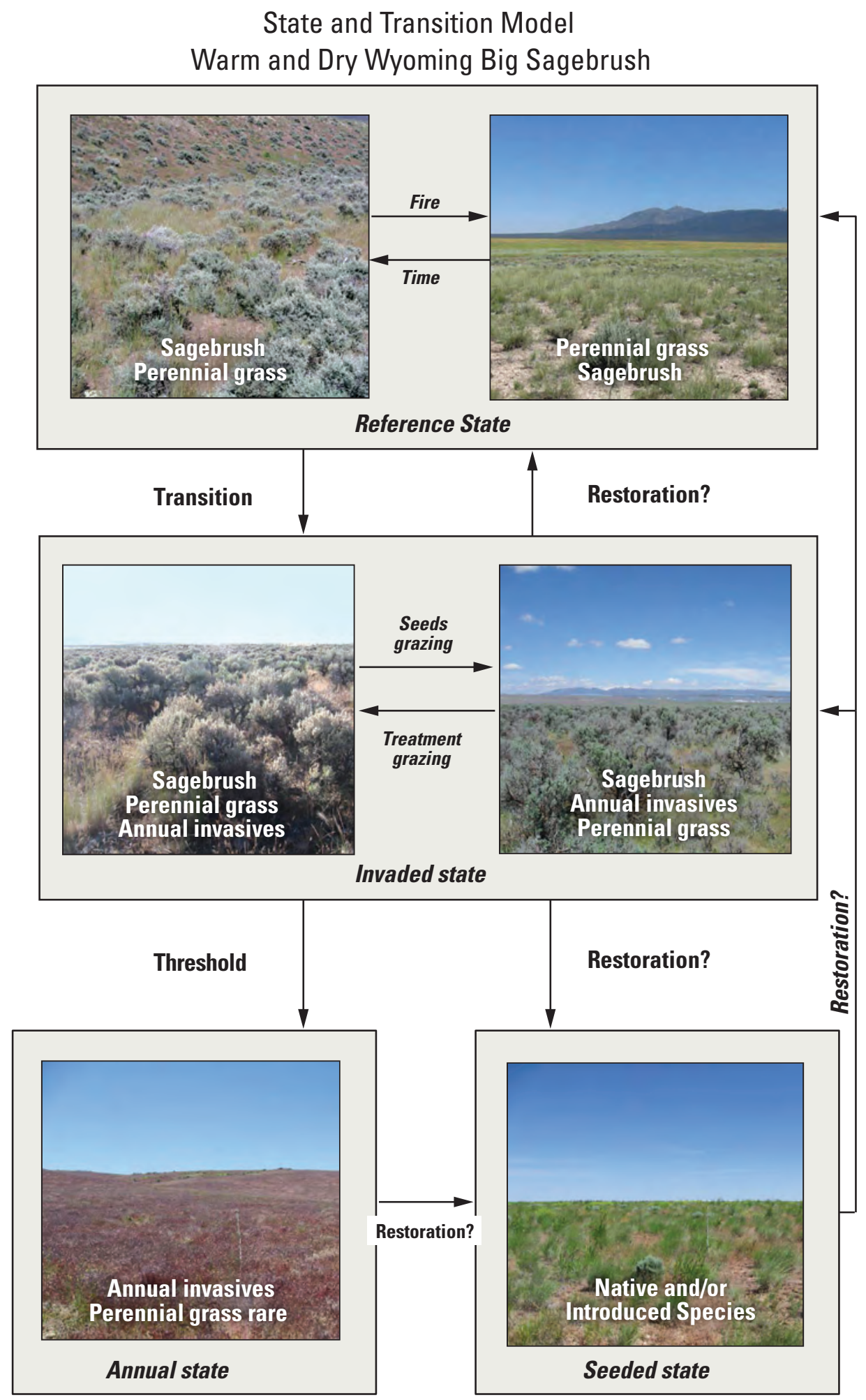

Reference state.-There is a continuum from shrub to grass dominance depending on time since fire and other factors like climate, insects, and pathogens.

Invaded state.-An invasive seed source and/or improper grazing result in a transition to an invaded state. Perennial grass decreases and invasive grasses increase with improper grazing or stressors resulting in an at-risk phase. Management treatments and proper grazing are unlikely to result in return to the reference on all but cool and moist sites.

Annual state.-Fire or other disturbances that remove sagebrush result in crossing a threshold to an annual state. Perennial grass is rare and recovery potential is low. Repeated fire causes further degradation.

Seeded state.-Seeding following fire and/or invasive species control results in a seeded state. Sagebrush may establish on cooler and moister sites. Success and return to the reference state are related to site conditions, seeding mix, and post-treatment weather, and livestock use.

Figure 6. State and transition conceptual model depicting successional dynamics for a generalized warm and dry sagebrush grassland community. This model illustrates four states that might exist on a given site given resilience to disturbances and resistance to invasion of non-native annual grasses. Photograph credits: Upper left, Jeanne Chambers, U.S. Forest Service, RMRS, 2008. All other photographs, Kevin Knutson, U.S. Geological Survey, 2011. 


\section{Restoration Actions}

Ecological restoration is the intentional activity that initiates or accelerates recovery of an ecosystem with respect to its health, integrity, and sustainability (Society for Ecological Restoration International Science and Policy Working Group, 2004). Restoration in the broadest sense includes rehabilitation and reclamation within its scope. Rehabilitation tends to have goals and objectives that are not intended to re-establish the entire plant community, but rather focuses on halting further degradation of sites and increasing resilience and resistance to future disturbances. For example, typical goals of post-wildfire rehabilitation relate to stabilizing soils from further erosion or stemming the increase in invasive plants. Reclamation often consists of rebuilding soil profiles to re-establish plants and protecting ecosystems from environmental contaminants. Examples of reclamation are often associated with mined lands.

Restoration may be separated into two forms - passive and active (McIver and Starr, 2001; Hemstrom and others, 2002). Passive restoration is often achieved by changing current management, which in turn allows natural processes to move plant communities to a desired composition and structure of species. Active restoration (for example, revegetation and severe modifications of plant communities using techniques that remove or restrict some species while favoring others) may be necessary if desired species were eliminated from sites or if the timeline for recovery is longer than desired to meet objectives through passive restoration (Pyke, 2011).

\section{Passive Restoration}

Passive restoration may achieve desired habitat changes if the degradation of habitat has not been too severe and the community has remained within the reference state or if an invaded state maintains sufficient perennial grasses and minor amounts of invasive annual grasses (fig. 6).

Common forms of passive restoration are removals, changes, or reductions of land uses, such as livestock grazing or recreation. Changes in season of use may at times be adequate to achieve desired responses. If the goal is to achieve increases in tall perennial grass composition, and these plants currently exist on a site, then ensuring reproduction of these existing grasses is paramount for providing propagules adequate germination, establishment, and survival. Defoliation that removes flowers or seeds before seeds can disperse prevents the possibility of perennial grass increase.
Grazing by domestic livestock, wild horses, and burros is the most widespread land use within sagebrush steppe ecosystems where adjustments in the type or magnitude of use, or both, might bring about passive restoration. Shifting to no livestock use may not provide desired outcomes, such as increases in perennial herbaceous components of the plant community, if state changes have occurred (West and others; 1984; Davies and others, 2009). This may be the case when annual grasses dominate and perennial grasses are underrepresented in the species mixture on a site.

Proper stocking rate and season of use to support light to moderate use of forage during the growing season is critical to ecological, animal production, and economic sustainability of rangelands (Briske and others 2011a, 2011b; Holecheck and others, 2011). Within the framework of proper stocking, managers can use herding, fencing, moving minerals and supplements, water availability and distribution, and other techniques to avoid overuse of specific areas to maintain proper use across a grazing unit. Beck and Mitchell (2000) and Boyd and others (2014) reviewed the literature and presented evidence for both positive and negative impacts of livestock grazing on sagegrouse habitats. Modifications to animal management might be considered as prescriptive techniques in conjunction with other ecosystem and management options to achieve desired habitat conditions. Shift from growing-seasonlong grazing to seasonal-rotational grazing practices for livestock throughout the Western United States has resulted in reported improvements to federal rangelands (U.S. General Accounting Office, 1977).

Season of use by livestock often differs between western and eastern parts of the sage-grouse range. The growing season in the Great Basin is generally late winter to late spring or early summer. Dormant grazing during the summer, autumn, or winter are likely the least disruptive to mature grass and forb growth and reproduction (Pechanec and Stewart, 1949; Mueggler, 1950; Bork and others, 1998; Roselle and others, 2010), but may require nutritional supplements for livestock to maintain or increase livestock production (Bork and others, 1998; Petersen and others, 2014). Many studies have indicated livestock using sagebrush during dormant periods for herbaceous plants may reduce sagebrush and benefit herbaceous vegetation through reduced competition from the shrubs (Wambolt and Watts, 1996; Petersen and others, 2014), but results have been mixed, and are either dependent on precipitation (Petersen and others, 2014) or have resulted in degraded habitat value for sage-grouse or other sagebrush-dependent wildlife (Wambolt and Watts, 1996). Caution is advised when using such approaches and monitoring potential positive and negative consequences is necessary to allow adaptations to management. Grazing in 
the early growing season likely will provide an optimum mix of livestock benefits with the least effect to perennial plant growth or reproduction, provided grazing ceases before reproductive shoots reach grazing height in the early boot stage. However, if the goal is to increase perennial grasses through natural seedling production, then hoof action during that same season may kill some seedlings and reduce any potential benefit of seed production. A lack of plant demographic information relative to livestock grazing seasons and seedling survival hinders the ability to make effective recommendations regarding passive approaches for improving native perennial grasses. Light to moderate stocking levels that yield light to moderated use, in combination with rest during the reproductive growth of perennial grasses, is likely to provide the greatest benefit for increasing perennial grasses within the Intermountain West (Briske and others, 2011a, 2011b).

In the Great Plains, the same grazing pattern of use would be optimal for cool-season grasses. For warm-season grasses, grazing could resume after seed dispersal of coolseason grasses and may continue until inflorescences of warm-season grasses are in the late boot stage, provided stocking levels are adequate for plant maintenance. The seasons of use in Wyoming Basin and the Colorado Plateau are somewhat intermediate and will depend on the dominance of cool-season as opposed to warm-season plants but the same principles apply; grazing during the reproductive phase of perennial grasses is generally harmful to grass growth and to increases in perennial grass cover (Briske and others, 2011a).

Resting pastures from grazing during periods of fastest growth of dominant perennial grasses and forbs tends to enhance perennial herbaceous plant growth and reproduction in sagebrush steppe (Hyder and Sawyer, 1951; Briske and Richards, 1995; Bork and others, 1998), and may reduce cheatgrass by increasing the competitive ability of perennial herbs (Strand and others, 2014). Pasture rest during this same period generally increases culm (grass stem) height, tiller production over the long term, and flower and seed production in the intermountain sagebrush steppe (Miller and others, 1994). If maintaining or increasing sage-grouse nesting and hiding cover are management goals, maintaining low stocking levels of livestock to achieve an average stubble height (Holechek and Galt, 2000) of $18 \mathrm{~cm}$ (Gregg and others, 1994; Connelly and others, 2000) may provide this cover. If the site potential does not allow grasses to achieve this height, then managing for some grasses to remain ungrazed may provide adequate hiding cover for sage-grouse. Although dormant season grazing can minimize impacts on plant health and productivity, it could be counter to the goal of the achieving adequate cover during the nesting season if grazing removes too much residual cover, so balance is needed in achieving both goals. Grazing influence on sage-grouse habitat is a function of both long-term management to promote desirable plant communities and annual management of the standing residual cover to meet seasonal cover requirements for sage-grouse (Cagney and others, 2010).

Grazing the herbaceous layer after the inflorescence is elevated within the culm in sagebrush grasslands tends to reduce defoliated perennial grasses in favor of plants avoided by grazers (Anderson and Briske, 1995). When the grazer is cattle, then sagebrush is the avoided plant that benefits from grazing the herbaceous layer at that phenologic stage (Mueggler, 1950; Laycock, 1967). Repeated grazing during this period allows sagebrush to become so dense that it can restrict recovery of herbaceous plants (Reichenberger and Pyke, 1990). Grazing during this period also may tend to remove grazing-sensitive grasses from interspaces between shrubs, restricting them to locations under shrub canopies where these grasses are protected from grazers. Most of these herbaceous plants located under shrub canopies must compete heavily with shrubs for resources (Reisner, 2010), and even though they are surviving, their ability to reproduce and spread is limited. Once this sagebrush and perennial grass relationship is achieved on a site, passive restoration may no longer be an option for restoring mixed stands of sagebrush and perennial grasslands (Rice and Westoby, 1978; West and others, 1984; Wambolt and Payne, 1986; Cagney and others, 2010). Targeted grazing may reduce sagebrush (Petersen and others, 2014), but perennial grass densities may be insufficient to produce new plants and fill the openings created by sagebrush (Wambolt and Watts, 1996). More research is necessary before prescriptive passive restoration using targeted grazing can be recommended for shifting dense sagebrush-dominated communities with low levels of perennial grasses to communities with equal dominance of sagebrush and perennial grasses that should benefit sage-grouse while being resilient to fires.

Passive restoration through adjustments in grazing seasons or reductions in livestock numbers may shift vegetation communities to favor more or larger perennial grasses provided that most perennial grasses are in interspaces away from shrub canopies and that those interspaces only have minor amounts of cheatgrass (Davies and others, 2014; fig. 6). The reference state community should retain sagebrush and bunchgrass densities necessary 
for quality habitat, especially for sage-grouse (Connelly and others, 2000, Crawford and others, 2004), but cover or height of grasses may be inadequate depending on the grazing season and the season of year when grass height is required for optimal bird habitat. Release from livestock grazing during the later portion of the growing season should allow full expression of vegetation height for hiding cover and nest protection. Improvements in cover and height may not be expressed fully in the next growing season but may take 3-5 years for preexisting plants to fully express the height and tiller density required to provide hiding cover. Livestock grazing, when it occurs during dormant or early growing season, must be at low enough stocking levels to maintain adequate standing dead tiller density and culm height to provide cover and protection. Stubble height, vegetation height, or cover pole monitoring (Toledo and others, 2010) may provide a measure to adjust livestock stocking levels to attain adequate plant densities and horizontal cover for sage-grouse. This form of passive restoration may take years with adequate weather, if seedling establishment of sagebrush or perennial grasses are required to increase proportional cover of either group. Studies tracking vegetation change after removal of livestock in big sagebrush steppe ecosystems generally indicate that plant proportions remained unchanged over time (Anderson and Holte, 1981; West and others, 1984; Anderson and Inouye, 2001) or took a minimum of 10-15 years for seed production, seedling establishment, and growth to occur, because these events may be episodic (Call and Roundy, 1991; Pyke, 1995).

\section{Active Restoration Compared to Rehabilitation}

A common goal shared between restoration and rehabilitation is renewal of ecosystem processes, productivity, structure, and function (Society for Ecological Restoration International Science and Policy Working Group, 2004). Restoration typically accomplishes this goal using a diversity of native species and life forms. Rehabilitation is defined as an alternative to the historical native plant community that provides similar structure and function without allowing further degradation of the site (Bradshaw, 1983; Aronson and others, 1993). Rehabilitation may use fewer species than restoration and include species introduced to the site or mixtures of native and introduced species that may only renew some structural or functional aspects of the reference state. Active restoration or rehabilitation is warranted when desired species or structural groups are poorly represented in communities to such a degree that they are not likely to recover in a management timeframe following removal of disturbances (an alternative stable state). Active restoration is warranted when (1) passive restoration will not allow restoration goals to be met in a reasonable timeframe (for example, it may require more than 30 years for some sagebrush subspecies to recover to pre-burn levels; Wambolt and others [2001]); (2) desired species are replaced by undesirable, frequently invasive species that already dominate or can eventually dominate the site; and (3) active restoration likely is to achieve the restoration objective. In sagebrush steppe ecosystems, invasive species of concern include, but are not limited to, annual bromes (for example, cheatgrass) and noxious weeds (for example, medusahead, North Africa grass [Ventenata dubia], and knapweeds). Expansion of native species from adjacent ecosystems, including juniper or pinyon pine (Miller and others, 2011), into sagebrush steppe ecosystems also is a concern. Depending on site conditions and disturbance history, these species can become dominant and lead to positive feedbacks that maintain their existence on the site and negatively impact desirable species such as sagebrush, and perennial grasses and forbs (Miller and others, 2011). A sagebrush site can progress along a transition into an alternative vegetation state, but transitions between states are often unidirectional and new states lack the resilience to return to the previous state.

Provided that soil erosion has been minimal and hydrologic processes are similar, the site may still retain the capacity to support reference native plant communities; thus, restoration is possible if biological constraints such as weedy competitors can be reduced and adequate moisture exists for successful germination and establishment of native plants. Other state changes, in contrast, can result in sufficient soil loss or changes in hydrologic function so the site is no longer capable of supporting former plant communities occurring in reference states (Davenport and others, 1998; Briske and others, 2006). Fires through sagebrush steppe ecosystems, where pinyon and juniper are dense, may create situations where soil erosion becomes significant (Pierson and others, 2014). If these abiotic changes are significant enough that the site can no longer support the previous reference plant community, then an eroded phase of an ecological site may exist with a different potential plant community or production. If restoration to the original plant reference state is no longer possible, rehabilitation may be a viable alternative (Bradshaw, 1983; Aronson and others, 1993). 


\section{Landscape as a Concept for Restoration}

Understanding landscape concepts is important to prioritize restoration to meet landscape as well as sitespecific objectives. A landscape is defined rather arbitrarily as a large area in total spatial extent, somewhere in size between sites (hectares or square kilometers [acres or square miles]) and regions (hundreds of thousands of square kilometers [tens of thousands of square miles]). The basic unit of a landscape is a patch, which is defined as a bounded area characterized by a similar set of conditions. A habitat patch, for example, may be the polygon representing a single land cover type. Landscapes consist of a mosaic of patches. The arrangement of these patches (landscape configuration or pattern) has a large influence on the way a landscape functions.

Landscapes are characterized by three primary features - quantity, composition, and configuration. Landscape quantity is the amount of any component in the landscape and is usually measured as a percentage. Landscape cover is the proportion of a land cover type within the landscape (see section, "What Is Cover?"). A landscape containing 65 percent sagebrush means that 65 percent of the total area of all patches within the landscape is classified as sagebrush for the dominant cover; 35 percent would consist of patches of non-sagebrush dominated land areas. In contrast, percentage ground cover is measured at sites and is an estimate of the percentage of the ground surface covered by a plant species. Management guidelines most frequently referenced for sage-grouse (Connelly and others, 2000) are based on ground cover at a site and not for the landscape. A prescription for late broodrearing habitat to contain 10 percent ground (canopy) cover of sagebrush and greater than 25 percent cover of grasses and forbs should not be extrapolated to a landscape.

Landscape composition describes the total representation of different land cover types that are present within the landscape. The relative proportions of different cover types within a landscape contribute to the entire landscape and provide information on how the landscape functions. A landscape containing a high mosaic of grasslands mixed with sagebrush has much different fire dynamics than one dominated solely by either sagebrush or grasslands. These landscapes also may have different preference values for sagebrush-dependent animal populations. Similarly, a landscape containing sagebrush and patches of juniper and pinyon has a lower preference for an animal such as sage-grouse than a landscape characterized by sagebrush and native grasses (Knick and others, 2013), in part because trees provide perches for predators. Landscape composition provides information on what is in the landscape but not how the different land cover types are arranged.

Landscape configuration is the spatial arrangement of patches and their relationship to each other. A landscape that has 50 percent landscape cover of sagebrush can be arranged such that sagebrush is all in one large patch or in a checkerboard mosaic of patches with and without sagebrush. Some wildlife may perceive these landscapes differently by favoring large patches of sagebrush over highly fragmented patches. Similarly, the configuration can have a large influence on how fire burns across the landscape.

\section{Fragmentation and Connectivity}

Habitat fragmentation measures the extent to which large contiguous areas of similar habitats (cover types) are broken into smaller, distinct, and separate patches in a landscape. As such, fragmentation is a function of landscape quantity (proportion or amount of different habitat or cover-type patches), composition (list of land cover types are present within the landscape), and configuration (patch sizes and arrangements). Habitat fragmentation can be either a natural or human-caused process, or a function of combined causes. Restoration should not be used to resolve natural fragmentation where soil or topographic differences create plant communities dominated by species other than sagebrush.

Connectivity is related to fragmentation and measures the relative continuity of a habitat or cover type across a landscape. Connectivity includes corridors, path width, and habitat quality, as landscape characteristics. The ability of wildlife populations to persist is directly related to population size, relative isolation, and number of connections to adjacent populations. Increasing habitat connectivity or continuity of sagebrush across a landscape is a primary objective in landscape restoration for sagegrouse habitat. Previous studies have indicated that continuous dominance of sagebrush for 4,000 ha or more is important for sustaining populations throughout the year (Leonard and others, 2000) and that areas of 3,200 ha of land dominated by sagebrush and centered on leks aid in nesting success (Walker and others, 2007). Therefore, restoration projects that might be able to connect small existing patches to create continuous patches of this size would be an effective method of reducing fragmentation and achieving habitat goals. 


\section{Hierarchical Arrangements in Landscapes}

Complete restoration of large areas, such as the Great Basin, is not possible within short time frames because personnel and logistical constraints permit only a small number of local restoration efforts in any one year. Consequently, restoration planning must be based on an understanding that ecosystems have a hierarchical organization (fig. 7). Within this hierarchy, each organizational level consists of an assemblage of patterns and processes found in smaller levels. Regions consist of landscapes, that consist of patches or sites that, in turn, consist of individual shrubs. This hierarchical approach to viewing sagebrush steppe ecosystems is paralleled by restoration decisions because individual site-specific projects interact within a larger mosaic to recreate a landscape. The form and function that the larger landscape needs to achieve is a self-sustaining sagebrush ecosystem, one in which many restoration projects should be suitable to maintain and enhance landscape objectives. For landscape species, such as the sage-grouse, restoration of habitat generally carries with it a species-centric objective of maintaining or increasing population size. Effective restoration of habitat to achieve this objective requires successful restoration of individual locations and placing those site-specific restoration projects in strategic landscape locations to achieve these goals.

\section{Sage-Grouse as a Landscape Species}

The sage-grouse is a species of concern throughout the range of sagebrush steppe ecosystems. The U.S. Fish and Wildlife Service (USFWS) concluded in 2010 that the sage-grouse warranted protection under the Endangered Species Act, but was precluded from listing because other higher priority species were more immediately threatened by extinction. The primary reasons for the listing decision were population declines due to the loss and fragmentation of habitat for this landscape-dependent species coupled with inadequate regulatory mechanisms to control development in critical habitat areas.

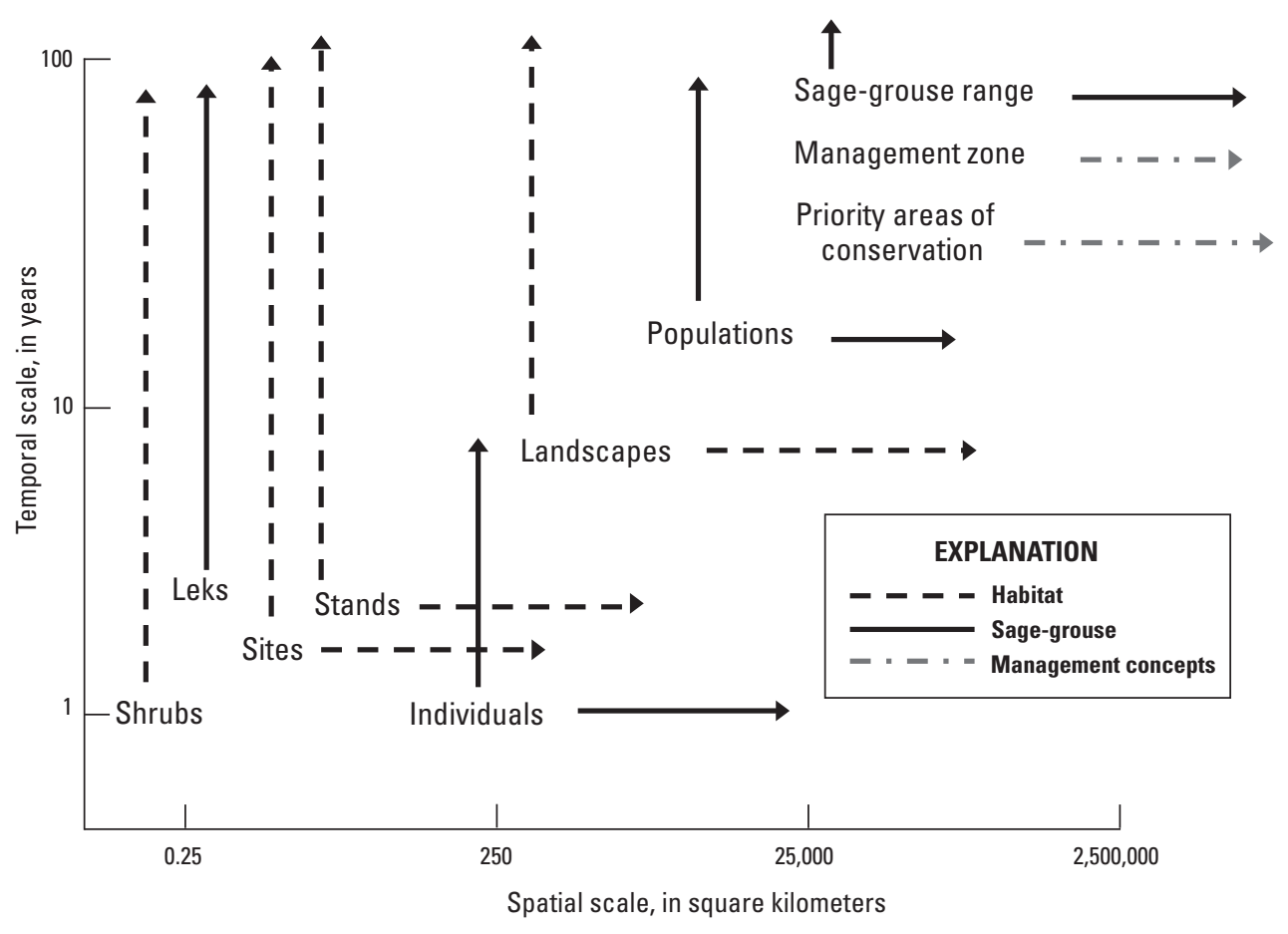

Figure 7. Hierarchy of patterns across spatial and temporal scales and the relationship to sage-grouse and their habitat. 
The USFWS will review the 2010 decision by 2015 . Consequently, there is an immediate need to take actions that will reduce threats to sage-grouse populations. State and Federal agencies, private landowners, and nongovernmental organizations are supporting efforts to restore habitats that benefit this bird, but tools are lacking that can aid decisions about where investments have the best probability of improving habitat for this landscape-level species. This background information and decision support Handbooks present information to aid this process and improve success at the landscape-level and the local or site-level. In both the background information and decision support Handbooks, the ultimate objective of successful restoration is viewed as halting or reversing declining population trends for sage-grouse.

Sage-grouse are considered to be a landscape species because their annual home range can cover hundreds of square miles. Although sage-grouse are totally dependent on sagebrush in some form, it is equally important to understand that simply restoring sagebrush at a location does not guarantee that sage-grouse will begin using that site. Previous use of a site by sage-grouse, relative distance and connectivity to other available habitat, size of the planned restoration, and the habitat in the surrounding region all influence the ability of a restoration project to benefit sage-grouse. Therefore, restoring landscapes suitable for sage-grouse requires not only actions to improve vegetation at individual sites, but strategic actions that increase the amount and connectivity of sagebrush habitats within the landscape. Decisions regarding what actions to take to achieve habitat goals also are complicated because sage-grouse use a variety of sagebrush-dominated habitats throughout any given year on seasonal ranges that can be separated by as much as $80 \mathrm{~km}$ (50 mi) (Fedy and others, 2012). The size of a landscape that influences sagegrouse is not well understood.

The current range of the sage-grouse has been divided into seven management zones that encompass the major populations of these birds (Stiver and others, 2006; fig. 8). Within these management zones, Priority Areas of Conservation (PAC) were identified by states as being crucial to ensure the representation, redundancy, and resilience for the conservation of populations (U.S. Fish and Wildlife Service, 2013). These PACs tend to closely follow remaining landscapes of large and intact cover of sagebrush.

\section{Sagebrush L andscape C over and Sage-Grouse.-}

The likelihood of sustaining sage-grouse leks appears to depend on the landscape cover of sagebrush, which can be used as an indicator of sage-grouse habitat across landscapes and regions (Aldridge and others,
2008; Wisdom and others, 2011; Knick and others, 2013). Chambers and others (2014c) have identified two breakpoints in the amount of landscape cover of sagebrush that can pertain to habitat management and restoration. There is a low probability of maintaining sage-grouse leks when landscape cover of sagebrush is less than 25 percent. However, when landscape cover of sagebrush exceeds 65 percent, the probability of sustaining active leks is high (fig. 9; Knick and others, 2013). Between about 25 and 65 percent landscape sagebrush cover, increases in landscape cover of sagebrush have a constant positive relationship with the probability of increases in sustaining sage-grouse leks (fig. 9; Knick and others, 2013). Restoration and management activities that increase landscape cover of sagebrush within areas of pre-existing landscape cover between 25 and 65 percent will likely result in a higher probability of sage-grouse presence and of potentially increasing leks or nesting success (Knick and others, 2013). Connecting existing patches of sagebrush to provide corridors among sagebrush habitat will likely pay higher dividends than restoring an isolated patch within a larger patch devoid of sagebrush.

By using a moving window (or rolling window) land cover mapping tool (Knick and others, 2013, Chambers and others, 2014c), landscape cover of sagebrush can be determined for sage-grouse (fig. 8) and patches can be categorized into these three groups. Large areas of landscape sagebrush cover greater than 65 percent primarily occur in Wyoming Basin, Snake River Plains, and northern Great Basin management zones. In contrast, high amounts of landscape cover of sagebrush only occur in relatively small areas in Great Plains, southern Great Basin, Columbia Basin, and Colorado Plateau management zones. In the western part of the range, where the threat of invasive annual grasses, tree encroachment, and wildfire is greatest, the area of sagebrush cover greater than 65 percent differs among management zones. The southern Great Basin management zone is a relatively arid and topographically diverse area in which the greatest extent of sagebrush cover greater than 65 percent is in high elevation, mountainous areas. The Snake River Plains and northern Great Basin management zones have relatively large extents of sagebrush cover greater than 65 percent in relatively cool and wet areas, and the Great Plains and Colorado Plateau management zones have lower extents of sagebrush cover greater than 65 percent in warm and dry areas and in areas with significant agricultural development. The combination of management zones, PACs, and landscape cover of sagebrush provide an initial means to identify and prioritize areas for restoration and management strategies (Chambers and others, 2014c). 


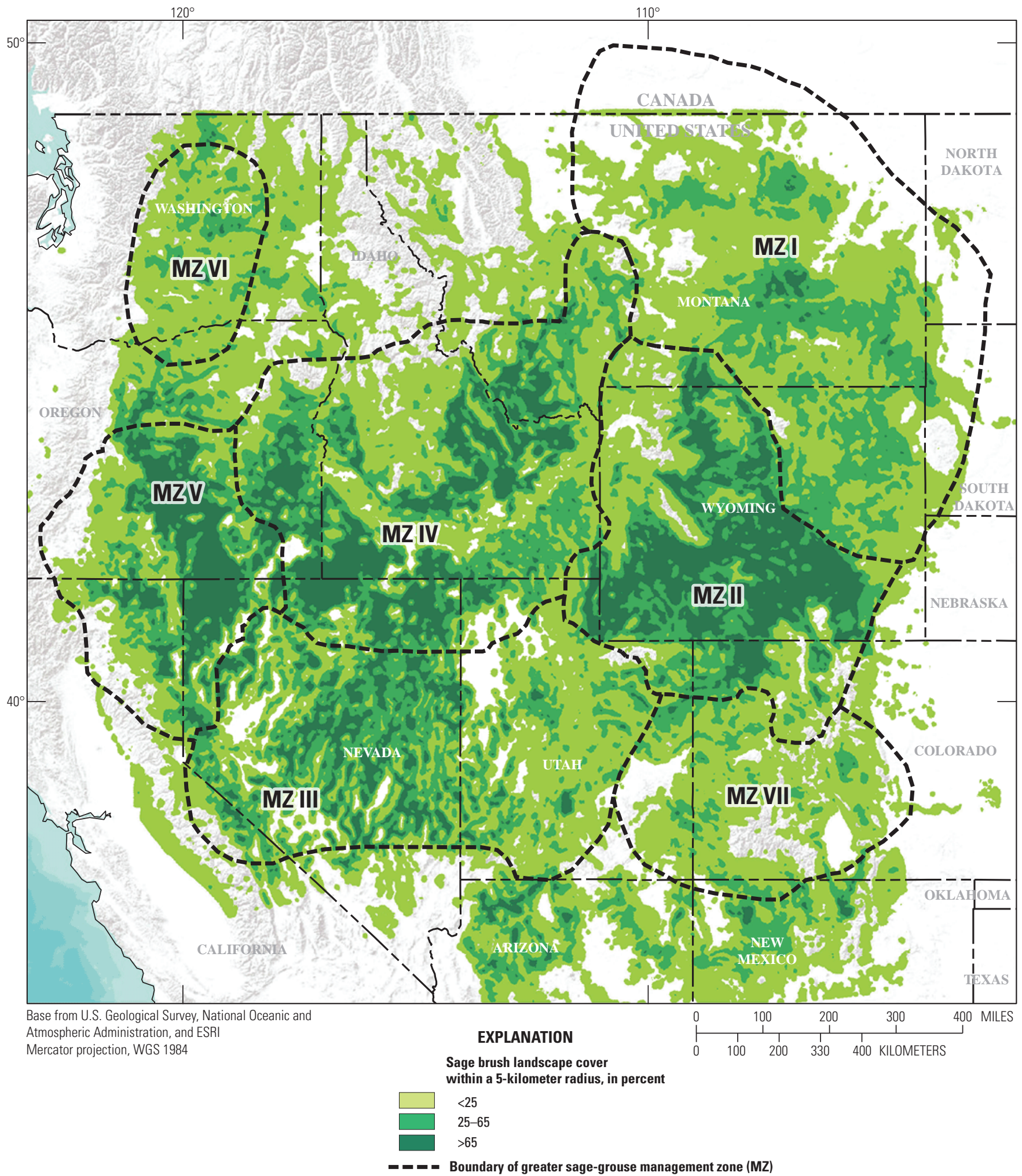

Figure 8. Landscape cover of sagebrush $(<25,25-65$, and $>65$ percent $)$ for the greater sage-grouse management zones. Landscape cover of sagebrush was determined from remote sensing images of land cover. The locations within the range of sage-grouse where adjacent areas of a set size (5-kilometer radius) have similar amounts of sagebrush dominance were calculated and delineated in a geographic information system format. See Chambers and others (2014c) for details on the methods used to develop this map. 


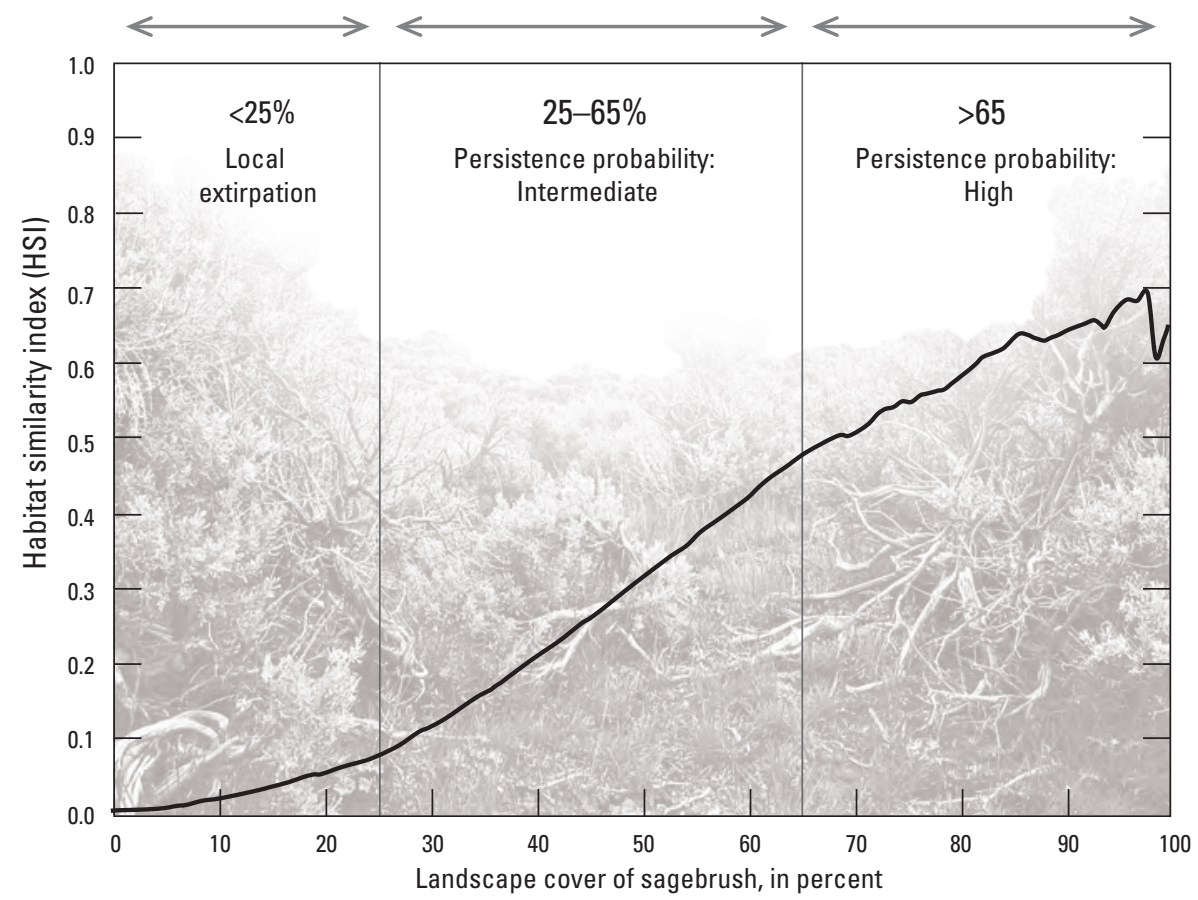

Figure 9. Proportion of sage-grouse leks and habitat similarity index (HSI) as related to the percentage of landscape cover of sagebrush. The HSI indicates the relationship of environmental variables at specific locations across the western part of the range to minimum requirements for greater sage-grouse defined by landscape cover of sagebrush. The categories at the top of the figure represent the break points of landscape cover of sagebrush that relate to lek persistence based on Aldridge and others (2008), Wisdom and others (2011), and Knick and others (2013). (Modified from Knick and others, 2013.)

\section{Sage-Grouse Seasonal Habitat Requirements}

Most of the studies identifying habitat needs of sage-grouse populations have focused on leks and nesting habitat largely because these locations are easily mapped and studies can identify the habitat surrounding these locations during stages when grouse travel short distances. Yet, habitat needs that extend beyond breeding to late brood rearing and winter habitat also are necessary for population persistence. Three major types of seasonal habitat for sage-grouse developed by Connelly and others (2000, 2011) include: (1) breeding (lekking, nesting, and early brood-rearing); (2) late-summer brood-rearing; and (3) winter. Connelly and others $(2000,2011)$ provide site-level recommendations for these habitats based on combinations of sagebrush and grass height (droop height) and percentage of ground cover (generally using line-intercept as the measure of cover) (table 3); however, individual State wildlife agencies may refine these recommendations based on local studies that could be used instead of these range-wide guidelines. Restoration of any of these types of habitat could be the goal of land managers, and vegetation goals incorporated in restoration objectives. Restoration success would be evaluated against these target goals through subsequent monitoring.

\section{B reeding Through E arly Brood-R earing Habitat.-}

This life stage encompasses lek use, nesting, and early brood-rearing habitat and occurs from March through June. For non-migratory birds, a large portion of these life stages will occur within about $3.2 \mathrm{~km}(2 \mathrm{mi})$ of the lek or a minimum area of about $32 \mathrm{~km}^{2}$ (7,950 acres) centered on the lek. Leks are traditional breeding areas where males display each year. Although the lek is a focal point for the population, the surrounding area is more important for habitat management. Most non-migratory females (about 80 percent) nest within $5 \mathrm{~km}(3 \mathrm{mi})$ of their leks. For migratory populations, females may travel $18 \mathrm{~km}(11 \mathrm{mi})$ to nest. It is important to understand the 
Table 3. Minimum height and canopy coverage recommendations for sagebrush and herbaceous (grass-forb) components in seasonal sage-grouse habitats.

[Adapted from Connelly and others, 2000. cm, centimeter; in., inch; NA, not applicable]

\begin{tabular}{|c|c|c|c|c|c|c|c|c|c|}
\hline \multirow{3}{*}{ Vegetation } & \multicolumn{3}{|c|}{ Breeding } & \multicolumn{3}{|c|}{ Late brood-rearing } & \multicolumn{3}{|c|}{ Winter } \\
\hline & \multicolumn{2}{|c|}{ Height } & \multirow{2}{*}{$\begin{array}{l}\text { Canopy } \\
\text { (percent) }\end{array}$} & \multicolumn{2}{|c|}{ Height } & \multirow{2}{*}{$\begin{array}{c}\text { Canopy } \\
\text { (percent) }\end{array}$} & \multicolumn{2}{|c|}{ Height } & \multirow{2}{*}{$\begin{array}{c}\text { Canopy } \\
\text { (percent) }\end{array}$} \\
\hline & cm & in. & & $\mathbf{c m}$ & in. & & $\mathbf{c m}$ & in. & \\
\hline Sagebrush & $>25$ & 10 & $>15$ & $>40$ & 16 & $>10$ & $>25$ & 10 & $>10$ \\
\hline Grass-forb & $>18$ & 7 & ${ }^{1}>15 ;{ }^{2}>25$ & \multicolumn{2}{|c|}{ Variable } & $>15$ & \multicolumn{2}{|c|}{ NA } & NA \\
\hline
\end{tabular}

${ }^{1}$ Arid sites.

${ }^{2}$ Mesic sites.

migratory tendencies of populations that are being managed to evaluate their habitat needs and current status. For successful nesting, female sage-grouse need large areas where sagebrush height and cover is greater than the average. Grass height guidelines of $18 \mathrm{~cm}$ (7 in.) suggest a reliance on medium-statured grasses; short grasses such as Sandberg bluegrass or blue grama are not likely to provide necessary heights for high quality nesting and hiding cover. Some State wildlife agencies have modified these guidelines for specific plant communities and those may be used for evaluations as well. For restoration purposes, Connelly and others (2011) proposed that no more than 20 percent of the landscape area in the breeding habitat should have sagebrush removed either intentionally or by wildfire within roughly a 30-year period to maintain adequate breeding habitat throughout the area surrounding leks. To our knowledge, this percentage has not been rigorously tested but until further information is available, this is likely a reasonable approach because any loss of sagebrush, even for long-term restoration, may have shortterm negative impacts on sage-grouse that can persist for longer than 20 years (Knick and Hanser, 2011; Hess and Beck, 2012).

For early brood-rearing habitat, forbs are important as a direct source of food and as an indirect source by providing habitat for insects. In particular, ants, beetles, and grasshoppers are the main component of chick sagegrouse diets during their first few weeks (Patterson, 1952; Johnson and Boyce, 1990). Any loss in forb cover may have important impacts on sage-grouse food availability because in most big sagebrush ecological sites forbs rank third in contributing cover or biomass to the overall relative dominance. Forb cover may be limited by site resources (for example, precipitation and soil depth); therefore, forb composition should be managed to maximize the site's potential within brood-rearing habitat, focusing especially on forbs that flower and fruit during the early brood-rearing period. Management practices to favor forb flower and fruit production will likely enhance early brood-rearing habitat.

L ate Brood-R earing Habitat.- This stage in the sage-grouse life cycle, occurring from June through August, is triggered by a shift from insects to more forbs in chick diets (table 4). There is a tendency for birds to move upslope to sagebrush communities at high elevations or to find sagebrush stands adjacent to wetlands, seeps, meadows, or riparian environments where forbs are more prominent. These moist environments should be maintained to provide prominent forb habitat. In eastern and southern parts of the sage-grouse range where summer moisture is more reliable, forbs may become more prominent. Historical sheep use in many of these ecosystems may have reduced forb diversity and abundance (Bork and others, 1998), so these sites might be excellent locations for forb restoration.

A utumn and Winter Habitat.- Autumn habitat tends to be transitional from late brood-rearing to winter habitat. Sage-grouse will continue to use forbs and insects while they remain available but, once these foods decrease in availability, sage-grouse will shift to feeding primarily on sagebrush leaves and will rely almost exclusively on sagebrush for food throughout winter. Winter habitats must provide sagebrush tall enough to stay above the snow so birds can forage. Exposed ridges often provide habitat because winds tend to blow snow from the ridges into drainages. Care should be taken to conserve all areas of sagebrush in sage-grouse winter range because suitable sagebrush for sage-grouse is often very limited in severe winters. 
Table 4. Forbs listed as foods for sage-grouse.

[Adapted from Miller and others, 2011. sp., species not specified]

\begin{tabular}{|c|c|c|}
\hline Species & Common name & Source \\
\hline Achillea millefolium & common yarrow & Miller and Eddleman, 2001 \\
\hline Agoseris sp. & mountain dandelion & Miller and Eddleman, 2001 \\
\hline Antennaria sp. & pussytoes & Black, 2011 \\
\hline Aster sp. & aster sp. & Black, 2011 \\
\hline Astragalus sp. & milkvetch sp. & Miller and Eddleman, 2001 \\
\hline Camelina microcarpa & littlepod false flax & Peterson, 1970 \\
\hline Castilleja sp. & Indian paintbrush & Miller and Eddleman, 2001 \\
\hline Crepis sp. & hawksbeard & Miller and Eddleman, 2001 \\
\hline Erigeron sp. & fleabane & Black, 2011 \\
\hline Eriogonum sp. & buckwheat & Miller and Eddleman, 2001 \\
\hline Gayophytum sp. & groundsmoke & Black, 2011 \\
\hline Grindelia squarrosa & curlycup gumweed & Peterson, 1970 \\
\hline Hedysarum sp. & sweetvetch & Black, 2011 \\
\hline Lactuca serriola & prickly lettuce & Miller and Eddleman, 2001 \\
\hline Lepidium densiflorum & common pepperweed & Peterson, 1970 \\
\hline Leptosiphon harknessii & Harkness' flaxflower & Miller and Eddleman, 2001 \\
\hline Lithophragma sp. & woodland-star & Gillan and Strand, 2010 \\
\hline Lomatium sp. & biscuitroot & Miller and Eddleman, 2001 \\
\hline Lotus sp. & trefoil & Gillan and Strand, 2010 \\
\hline Medicago sativa & alfalfa & Peterson, 1970 \\
\hline Microsteris gracilis & slender phlox & Miller and Eddleman, 2001 \\
\hline Orobanche sp. & broomrape & Black, 2011 \\
\hline Phlox longifolia & longleaf phlox & Miller and Eddleman, 2001 \\
\hline Polygonum sp. & knotweed & Black, 2011 \\
\hline Taraxacum officinale & common dandelion & Miller and Eddleman, 2001 \\
\hline Tragopogon dubius & yellow salsify & Miller and Eddleman, 2001 \\
\hline Trifolium macrocephalum & largehead clover & Miller and Eddleman, 2001 \\
\hline Vicia sp. & vetch & Black, 2011 \\
\hline
\end{tabular}

\section{Restoration Methods of Sagebrush Steppe Ecosystems for Sage-Grouse Habitat}

Effective restoration of sagebrush steppe ecosystems for sage-grouse habitat will require strategic choices regarding where to target restoration and what approaches will likely succeed in providing habitat. Because sagegrouse are landscape birds that have a west-wide distribution, managers making decisions on where to conduct restoration will benefit from using landscape decision tools to direct restoration and management into locations where sage-grouse will likely achieve the greatest benefit. At the site level, active restoration throughout sagebrush steppe ecosystems has been thoroughly reviewed by a number of sources (Monsen and others 2004a, 2004b, 2004c; Hardegree and others, 2011; Pyke and others, 2013). Here we only will present information gleaned from these reviews that pertains to successful sagebrush ecosystem restoration. Establishment of sagebrush is clearly an important habitat factor for sage-grouse, but beyond studies on big sagebrush (Artemisia tridentata), little is known about propagation of other shrub species (McArthur and Stevens, 2004). Sagebrush has one of the smallest seeds of species commonly sown on rangelands. Big sagebrush subspecies may range from just less than 900,000 seeds/ $\mathrm{kg}$ (2 million seeds/lb) for Wyoming big sagebrush to 1.1 million seeds $/ \mathrm{kg}$ (2.5 million seeds/lb) for mountain big sagebrush (McArthur and Stevens, 2004). Techniques for seeding sagebrush, such as aerial broadcast, surface broadcast, seed dribbler, or any type of seeding that allows seed to remain at the soil surface, require soil disturbance or compaction to provide good soil-to-seed contact. Harrowing or chaining to break up the soil surface and allow the seed to fall in locations where slight soil sloughing will occur, or seeding on the surface followed by a cultipacker or other equipment that can press seeds into 
the soil surface, are reported to work best (McArthur and Stevens, 2004). Seeds buried too deeply either germinate and die before reaching the surface or may become dormant until they reach light to stimulate germination (Wijayratne and Pyke, 2012). Aerial seeding without these additional measures has consistently failed on wildfire rehabilitation treatment areas (Knutson and others, 2014).

Transplanting sagebrush is a method to consider in conjunction with reseeding. Transplants of sagebrush tend to have higher degrees of success relative to seeding provided that basic procedures are followed in conducting the transplanting (Shaw, 2004; Davies and others, 2013; Dettwiler-Robertson and others, 2013; McAdoo and others, 2013). It may not be cost effective to transplant an entire restoration site to achieve full sagebrush occupancy, but it may be possible to establish scatter islands of sagebrush throughout a project or widely spaced shrubs to form seed sources for additional spread of sagebrush during future favorable conditions at nearly equal costs but with greater potential for successful establishment (Knutson and others, 2014). Although this might be a slow process, it closely mimics natural dispersal after fires, where small patches of shrubs would become the parent plants for future establishment and spread.

Selecting appropriate species and subspecies for a site also is critical for success and has been a past problem in sagebrush establishment and survival (Lysne and Pellant, 2004). The ability to purchase source-identified seeds (Young, 1995) provides managers assurances that they are getting the appropriate taxon while also providing information on the general location from which seeds were collected. Source-identified seeds should aid in making certain that local genotypes are sown; this has been shown as important for the sustainability of sagebrush (Meyer and others, 1990; Meyer and Monsen, 1991, 1992).

Perennial grasses are the most important life form for achieving at least partial restoration success of sagebrush steppe ecosystems because perennial grasses add the greatest resilience (Chambers and others, 2014a). In general, this group of species is more successful as elevation and precipitation increase and soils become cooler and moister throughout the region (Knutson and others, 2014). Using a seed drill to plant seeds aids establishment and allows for more success in warm and dry environments (Hardegree and others, 2011; Knutson and others, 2014), but many cool and moist sites may be capable of unassisted recovery. Because seed size may vary among species, seeding depth is commonly an important factor relating to seeding success (Hardegree and others, 2011). Recommended seeding depths by species are reported in Monsen and Stevens (2004). Depth bands are commonly applied to drills to insure the appropriate seeding depth is achieved and should be used as a best management practice when seeding species in sagebrush steppe ecosystems. Multiple seed boxes that feed seeds of different sizes or with appendages (for example, awns and plumes) into different seed tubes on drills may be necessary to seed species that require different depths or further mixing to pass through seeding tubes.

Forbs are important for sage-grouse brood rearing and should be included when possible on restoration projects. Forbs will generally make up a lesser proportion of the seed mixture than grasses because in most sagebrush steppe ecosystems they are a minor component. The exceptions will be on cool and moist sites where forbs may be more prominent. Dormancy and seeding depths will vary among forb species, thus managers who seed forbs need to be aware of these factors because they may affect their initial germination and emergence.

Matching the appropriate plant species to the site is critical for sustaining sage-grouse habitat and so that correct plant genotypes are matched to environments where they are adapted to survive. The ecological site description provides the best source of information regarding the native species that typically germinate and sustain populations on an ecological site. Should managers desire to sow introduced species on a site, they will need to consult individual plant guides with the species descriptions in the PLANTS Database (http://plants.usda.gov) to match adaptations to environmental characteristics of the site. In addition, caution should be used in seeding native plants with introduced grass or shrub species since Knutson and others (2014) reported that these mixtures did not increase native plant cover and those native plants sown only with natives tended to produce more cover than those sown with introduced plants.

Lastly, biological soil crusts should be considered when any planting effort is likely to disturb soils. Maintenance of biological soil crusts is extremely important where they exist. Minimum-tillage seed drills are less disruptive to the soil surface and may provide a mechanism to achieve restoration while maintaining as much crust as possible. The use of harrows or chains in these environments may enhance plant germination, but the loss of immediate soil stability may erode soils creating long-term effects for site potential, thereby defeating the ultimate goal of establishing functioning sagebrush steppe ecosystems. Careful consideration should be given to the consequences of restoration actions on these minute yet important components of the ecosystem. 


\section{Monitoring and Adaptive Management Conclusions}

The ultimate question remains to be answered: if we restore habitat for any target species, such as sage-grouse, will that species use the habitat and will they sustain or increase populations over time? From a landscape perspective, it is important to monitor sage-grouse population trends (for example, lek counts) and vital rates (for example, nest success and survival) within areas where restoration activities have the goal of improving sagegrouse habitat. Monitoring sagebrush landscape cover also will be an important factor to track. As restoration activities begin, there may not be detectable changes in landscape cover for 10-40 years depending on elevation because it may require that amount of time for sagebrush to become dominant where it is planted (Miller and others, 2013). Therefore, realistic short-term and long-term objectives for cover and sage-grouse responses are important, in addition to tracking and reporting these values within meaningful landscape units, for example, PAC. If restoration efforts extend beyond the PAC, then monitoring those areas outside the PAC would be prudent.

Monitoring the effectiveness of restoration treatments at the site or project level should include a combination of a management and sampling objectives that will help guide future management (Elzinga and others, 2001). There may be numerous objectives relating to a restoration project. Objectives can be written that explain the desirable outcome for each life form such as shrubs, perennial grasses and forbs, and annual grasses and forbs. The objective should also include the location in question, the attribute that will be measured (for example, density or cover), the action that is anticipated with restoration (for example, increase, decrease, maintain), the quantity or measurable status that is anticipated, and the timeframe.

As much as possible, accepted techniques should be used so that they may contribute to range-wide monitoring to determine if certain objectives are achieved in certain locations. One approach is the BLM Assessment, Inventory and Monitoring strategy. Core methods for site-specific monitoring are available (Taylor and others, 2012) with addition methods, such as density of seedlings, shrubs, and perennial grasses, added to enhance monitoring of the effectiveness of the projects (Herrick and others, 2009). Restoration plans and activities including objectives may be easily retrieved and tracked provided they are filed in a treatment archive such as the Land Treatment Digital Library (Welty and Pilliod, 2013). Monitoring data could benefit from a similar archival system that allows similar projects to be filed together.
Restoration of an ecosystem is a daunting task that appears insurmountable at first, but as with any large-scale undertaking, the key is breaking down the process into the essential components to successfully meet objectives. Within the sagebrush steppe ecosystem, restoration is likely to be most successful once we understand the parts of the ecosystem that are resilient to disturbances and are resistant to invasive plant dominance. By dividing lands into these components, we can anticipate where available resources for active restoration can achieve the greatest success, and also understand where mere management changes (passive restoration) may elicit desired responses. In addition, we can better understand where appropriate land treatment may result in a desired outcome and where inappropriate treatment may lead to unintended degradation of the ecosystem. Blending ecosystem realities with speciesspecific needs provides an ecologically based framework for strategically focusing restoration measures to support species of conservation concern over the short and long term.

By using the concepts established here, we set the stage for two decision support tools. One will address decisions relating to landscape objectives and outcomes and the second relates to site-specific restoration.

\section{Acknowledgments}

This is Contribution Number 3 of the Sagebrush Steppe Treatment Evaluation Project (SageSTEP), funded by the U.S. Joint Fire Science Program (05-S-08), the National Interagency Fire Center, the Bureau of Land Management, the Great Northern Land Conservation Cooperative, and the U.S. Geological Survey. Additional funding was provided by the Western Association of Fish and Wildlife Agencies (WAFWA) through an agreement with Pheasants Forever and the Intermountain West Joint Venture under the Sage-Grouse Initiative Strategic Watershed Action Team (SGI SWAT). We thank members of the WAFWA Sage and Columbia Sharp-tail Grouse Technical Committee for their guidance and input on this project. We thank S. Hardegree and K. Veblen peer reviews that greatly improved this handbook. 


\section{References Cited}

Aldridge, C.L., Nielsen, S.E., Beyer, H.L., Boyce, M.S., Connelly, J.W., Knick, S.T., and Schroeder, M.A., 2008, Range-wide patterns of greater sage-grouse persistence: Diversity and Distributions, v. 14, p. 983-994.

Alexander, E.B., Mallory, J.I., and Colwell, W.L., 1993, Soilelevation relationships on a volcanic plateau in the southern Cascade Range, northern California, USA: Catena, v. 20, p. $113-128$.

Anderson, J.E., and Holte, K.E., 1981, Vegetation development over 25 years without grazing on sagebrushdominated rangeland in southeastern Idaho: Journal of Range Management, v. 34, p. 25-29.

Anderson, J.E., and Inouye, R.S., 2001, Landscape-scale changes in plant species abundance and biodiversity of a sagebrush steppe over 45 years: Ecological Monographs, v. 71, p. 531-556.

Anderson, V.J., and Briske, D.D., 1995, Herbivore-induced species replacement in grasslands: is it driven by herbivory tolerance or avoidance: Ecological Applications, v. 5, p. $1,014-1,024$.

Aronson, J., Floret, C., Le Floc'h, E., Ovalle, C., and Pontanier, R., 1993, Restoration and rehabilitation of degraded ecosystems in arid and semiarid lands, I. A view from the south: Restoration Ecology, v. 1, p. 8-17.

Beatley, J.C., 1966, Ecological status of introduced brome grasses (Bromus spp.) in desert vegetation of southern Nevada: Ecology, v. 47, p. 548-554.

Beck, J.L., Connelly, J.W., and Wambolt, C.L., 2012, Consequences of treating Wyoming big sagebrush to enhance wildlife habitats: Rangeland Ecology and Management, v. 65, p. 444-455.

Beck, J.L., and Mitchell, D.L., 2000, Influences of livestock grazing on sage grouse habitat: Wildlife Society Bulletin, v. 28 , p. $993-1,002$.

Beisner, B.E., Haydon, D.T., and Cuddington, K., 2003, Alternative stable states in ecology: Frontiers in Ecology, v. 1 , p. $376-382$.

Belnap, J., and Eldridge, D., 2001, Disturbance and recovery of biological soil crusts, in Belnap, J., and Lange, O.L., eds., Biological soil crusts-Structure, function, and management: Berlin, Germany, Springer-Verlag, p. 363-384.

Bilbrough, C.J., and Richards, J.H., 1993, Growth of sagebrush and bitterbrush following simulated winter browsing: mechanisms of tolerance: Ecology, v. 74, p. 481-492.
Black, T.A., 2011, Sage-grouse habitat in Utah-A guide for landowners and managers: Logan, Utah State University, All Current Publications, Paper 67, 63 p. [Also available at http://digitalcommons.usu.edu/extension_curall/67.]

Booth, M.S., Caldwell, M.M., and Stark, J.M., 2003, Overlapping resource use in three Great Basin speciesImplications for community invisibility and vegetation dynamics: Journal of Ecology, v. 91, p. 36-48.

Bork, E.W., West, N.E., and Walker, J.W., 1998, Cover components on long-term seasonal sheep grazing treatments in three-tip sagebrush steppe: Journal of Range Management, v. 51, p. 293-300.

Boyd, C.S., Beck, J.L., and Tanaka, J.A., 2014, Livestock grazing and sage-grouse habitat-Impacts and opportunities: Journal of Rangeland Applications, v. 1, p. 58-77.

Bradford, J.B., and Lauenroth, W.K., 2006, Controls over invasion of Bromus tectorum - The importance of climate, soil, disturbance and seed availability: Journal of Vegetation Science, v. 17, p. 693-704.

Bradley, B.A., 2009, Regional analysis of the impacts of climate change on cheatgrass invasion shows potential risk and opportunity: Global Change Biology, v. 15, p. 196-208.

Bradley, B.A., 2010, Assessing ecosystem threats from global and regional change-Hierarchical modeling of risk to sagebrush ecosystems from climate change, land use, and invasive species in Nevada, USA: Ecography, v. 33, p. 198-208.

Bradshaw, A.D., 1983, The reconstruction of ecosystems: Journal of Applied Ecology, v. 20, p. 1-17.

Briske, D.D., Fuhlendorf, S.D., and Smeins, F.E., 2006, State-and-transition models, thresholds, rangeland health-A synthesis of ecological concepts and perspectives: Rangeland Ecology and Management, v. 58, p. 1-10.

Briske, D.D., and Richards, J.H., 1995, Plant responses to defoliation: a physiologic, morphologic and demographic evaluation, in Bedunah, D.J., and Sosebee, R.E., eds., Wildland plants-Physiological ecology and developmental morphology: Denver, Colorado, Society for Range Management, p. 635-710.

Briske, D.D., Derner, J.D., Milchunas, D.G., and Tate, K.W., 2011a, An evidence-based assessment of prescribed grazing practices, in Briske, D.D., ed., Conservation benefits of rangeland practices: assessment, recommendations, and knowledge gaps: Washington D.C., U.S. Department of Agriculture, Natural Resources Conservation Service, p. 22-74. 
Briske, D.D., Sayre, N.F., Huntsinger, L., FernandezGimenez, M., Budd, B., and Derner, J.D., 2011b, Origin, persistence, and resolution of the rotational grazing debate-Integrating human dimensions into rangeland research: Rangeland Ecology and Management, v. 64, p. 325-334.

Brooks, M.L., and Chambers, J.C., 2011, Resistance to invasion and resilience to fire in desert shrublands of North America: Rangeland Ecology and Management, v. 64, p. 431-438.

Brooks, M.L., D’Antonio, C.M., Richardson, D.M., Grace, J.B., Keeley, J.E., DiTomaso, J.M., Hobbs, R.J., Pellant, M., and Pyke, D., 2004, Effects of invasive alien plants on fire regimes: BioScience, v. 54, p. 677-688.

Bukowski, B.E., and Baker, B.L., 2013, Historical fire regimes, reconstructed from land-survey data, led to complexity and fluctuation in sagebrush landscapes: Ecological Applications, v. 23, p. 546-564.

Cagney, J., Bainter, E., Budd, B., Christiansen, T., Herren, V., Holloran, M., Rashford, B., Smith, M., and Williams, J., 2010, Grazing influence, objective development, and management in Wyoming's greater sage-grouse habitat with emphasis on nesting and early brood rearing: Laramie, Wyoming, University of Wyoming Cooperative Extension Service B-1203, $57 \mathrm{p}$.

Call, C.A., and Roundy, B.A., 1991, Perspectives and processes in revegetation of arid and semarid rangelands: Journal of Range Management, v. 44, p. 543-549.

Caudle, D., DiBenedetto, J., Karl, M., Sanchez, H., and Talbot, C., 2013, Interagency ecological site handbook for rangelands: Interagency Ecological Site Handbook, 108 p., accessed October 4, 2013, at http://jornada.nmsu.edu/sites/ jornada.nmsu.edu/files/InteragencyEcolSiteHandbook.pdf.

Chambers, J.C., Bradley, B.A., Brown, C.S., D'Antonio, C., Germino, M.J., Grace, J.B., Hardegree, S.P., Miller, R.F., and Pyke, D.A., 2014b, Resilience to stress and disturbance, and resistance to Bromus tectorum L. invasion in cold desert shrublands of western North America: Ecosystems, v. 17, p. 360-375, doi:10.1007/s10021-013-9725-5.

Chambers, J.C., Miller, R.F., Board, D.I., Grace, J.B., Pyke, D.A., Roundy, B.A., Schupp, E.W., and Tausch, R.J., 2014a, Resilience and resistance of sagebrush ecosystems: implications for state and transition models and management treatments: Rangeland Ecology and Management, v. 67, p. $440-454$.
Chambers, J.C., Pendleton, B.K., Sada, D.W., Ostoja, S.M., and Brooks, M.L., 2013, Maintaining and restoring sustainable ecosystems, in Chambers, J.C., Brooks, M.L., Pendleton, B.K., and Raish, C.B., eds., The southern Nevada agency partnership science and research synthesis - Science to support land management in southern Nevada: Fort Collins, Colorado, U.S. Department of Agriculture, Forest Service, Rocky Mountain Research Station, General Technical Report, RMRS-GTR-303, 207 p.

Chambers, J.C., Pyke, D.A., Maestas, J.D., Pellant, M., Boyd, C.S., Campbell, S., Espinoza, S., Havelina, D., Meyer, K.E., and Wuenschel, A., 2014c, Using resistance and resilience concepts to reduce impacts of invasive annual grasses and altered fire regimes on the sagebrush ecosystem and sage-grouse-A strategic multi-scale approach: Fort Collins, Colorado, U.S. Department of Agriculture, Forest Service, Rocky Mountain Research Station, General Technical Report, RMRS-GTR-326, 73 p.

Chambers, J.C., Roundy, B.A., Blank, R.R., Meyer, S.E., and Whittaker, A., 2007, What makes Great Basin sagebrush ecosystems invasible by Bromus tectorum?: Ecological Monographs, v. 77, p. 117-145.

Chapin III, F.S., Torn, S.E., and Tateno, M., 1996, Principles of ecosystem sustainability: American Naturalist, v. 148, p. $1,016-1,037$.

Condon, L., Weisberg, P.L., and Chambers, J.C., 2011, Abiotic and biotic influences on Bromus tectorum invasion and Artemisia tridentata recovery after fire: International Journal of Wildland Fire, v. 20, p. 1-8.

Connelly, J.W., Schroeder, M.A., Sands, A.R., and Braun, C.E., 2000, Guidelines to manage Sage Grouse populations and their habitats: Wildlife Society Bulletin, v. 28 , p. $967-985$.

Connelly, J.W., Rinkes, E.T., and Braun, C.E., 2011, Characteristics of greater sage-grouse habitats-A landscape species at micro and macro scales, in Knick, S.T., and Connelly, J.W., eds., Greater Sage-Grouse-Ecology and conservation of a landscape species and its habitats: Berkeley, California, University of California Press, Studies in Avian Biology, v. 38, p. 69-84.

Crawford, J.A., Olsen, R.A., West, N.E., Mosley, J.C., Schroeder, M.A., Whitson, T.D., Miller, R. F., Gregg, M.A., and Boyd, C.S., 2004, Ecology and management of sage-grouse and sage-grouse habitat: Journal of Range Management, v. 57, p. 2-19.

Dahlgren R.A, Boettinger, J.L., Huntington, G.L., and Amundson, R.G., 1997, Soil development along an elevational transect in the western Sierra Nevada: Geoderma, v. 78, p. 207-236. 
Davenport, D.W., Breshears, D.D., Wilcox, B.P., and Allen, C.D., 1998, Viewpoint: sustainability of piñonjuniper ecosystems - a unifying perspective of soil erosion thresholds: Journal of Range Management, v. 51, p. 231-240.

Davies, G.M., Bakker, J.D., Dettweiler-Robinson, E., Dunwiddie, P.W., Hall, S.A., Downs, J., and Evans, J., 2012, Trajectories of change in sagebrush-steppe vegetation communities in relation to multiple wildfires: Ecological Applications, v. 22, p. 1,562-1,577.

Davies, K.W., Boyd, C.S., and Nafus, A.M., 2013, Restoring the sagebrush component in crested wheatgrass-dominated communities: Rangeland Ecology and Management, v. 66, p. $472-478$.

Davies, K.W., Svejcar, T.J., and Bates, J.D., 2009, Interaction of historical and nonhistorical disturbances maintain native plant communities: Ecological Applications, v. 19, p. $1,536-1,545$.

Davies, K.W., Vavra, M., Schultz, B., and Rimbey, N., 2014, Implications of longer term rest from grazing in the sagebrush steppe: Journal of Rangeland Applications, v. 1, p. 14-34.

Dettweiler-Robertson, E., Bakker, J.D., Evans, J.R., Newsome, H., Davies, G.M., Wirth, T.A., Pyke, D.A., Easterly, R.T., Salstrom, D., and Dunwiddie, P.W., 2013, Outplanting Wyoming big sagebrush following wildfire: stock performance and economics: Rangeland Ecology and Management, v. 66, p. 657-666.

Ehleringer, J.R., 1978, Implications of Quantum Yield Differences on the Distributions of $\mathrm{C}_{3}$ and $\mathrm{C}_{4}$ Grasses: Oecologia, v. 31, p. 255-267.

Elzinga, C.L., Salzer, D.W., Willoughby, J.W., and Gibbs, J.P., 2001, Monitoring plant and animal populations: Malden, Massachusetts, Blackwell Science, 372 p.

Fedy, B.C., Aldridge, C.L., Doherty, K.E., O’Donnell, M., Beck, J.L., Bedrosian, B., Holloran, M.J., Johnson, G.D., Kaczor, N.W., Kirol, C.P., Mandich, C.A., Marshall, D. McKee, G., Olson, C., Swanson, C.C., and Walker, B.L., 2012, Interseasonal movements of greater sage-grouse, migratory behavior, and an assessment of the core regions concept in Wyoming: Journal of Wildlife Management, v. 76 , p. $1,062-1,071$.

Gillan, J.K., and Strand, E.K., 2010, Sage-grouse habitat in Idaho-A practical guide for land owners and managers: Moscow, Idaho, University of Idaho, Wildlife and Range Experiment Station, Contribution Number 1048, 64 p.

Gregg, M.A., Crawford, J.A., Drut, M.S., and DeLong, A.K., 1994, Vegetational cover and predation of sage grouse nests in Oregon: Journal Wildlife Management, v. 58, p. 162-166.
Hardegree, S.P., Jones, T.A., Roundy, B.A., Shaw, N.L., and Monaco, T.A., 2011, Assessment of range planting as a conservation practice, in Briske, D.D., ed.,

Conservation benefits of rangeland practices: assessment, recommendations, and knowledge gaps: Lawrence, Kansas, Allen Press, U.S. Department of Agriculture, Natural Resource Conservation Service, p. 171-212.

Harris, G.A., 1967, Some competitive relationships between Agropyron spicatum and Bromus tectorum: Ecological Monographs, v. 37, p. 89-111.

Hemstrom, M.A., Wisdom, M.J., Hann, W.J., Rowland, M.M., Wales, B.C., and Gravenmier, R.A., 2002, Sagebrush-steppe vegetation dynamics and restoration potential in the Interior Columbia Basin, U.S.A.: Conservation Biology, v. 16, p. 1,243-1,255.

Herrick, J.E., Van Zee, J.W., Havstad, K.M., Burkett, L.M., and Whitford, W.G., 2009, Monitoring manual for grassland, shrubland, and savanna ecosystems: Las Cruces, New Mexico, U.S. Department of Agriculture, Agricultural Research Service, Jornada Experimental Range, 200 p.

Hess, J.E., and Beck, J.L., 2012, Disturbance factors influencing greater sage-grouse lek abandonment in northcentral Wyoming: Journal of Wildlife Management, v. 76, p. $1,625-1,634$.

Hobbs, R.J., Higgs, E.S., and Hall, C.M., 2013, Novel ecosystems-Intervening in the new ecological world order: Hoboken, New Jersey, Wiley-Blackwell, 380 p.

Holechek, J., and Galt, D., 2000, Grazing intensity guidelines: Rangelands, v. 22, p. 311-14.

Holechek, J.L., Pieper, R.D., and Herbel, C.H., 2011, Range management-Principles and practices (6 ed.): New York, Prentice Hall, 456 p.

Hyder, D.N., and Sawyer, W.A., 1951, Rotation-deferred grazing as compared to season-long grazing on sagebrushbunchgrass ranges in Oregon: Journal of Range Management, v. 4, p. 30-34.

Jackson, S.T., 2006, Vegetation, environment, and time: the origination and termination of ecosystems: Journal of Vegetation Science, v. 17, p. 549-557.

James, J.J., Davies, K.W., Sheley, R.L., and Aanderud, Z.T., 2008, Linking nitrogen portioning and species abundance to invasion resistance in the Great Basin: Oecologia, v. 156, p. 637-648.

Johnson, D.D., and Miller, R.F., 2006, Structure and development of expanding western juniper woodlands as influenced by two topographic variables: Forest Ecology and Management, v. 229, p. 7-15. 
Johnson, G.D., and Boyce, M.S., 1990, Feeding trials with insects in the diet of sage grouse chicks: Journal of Wildlife Management, v. 54, p. 89-91.

Knapp, P.A., 1995, Intermountain West lightning-caused fires - Climatic predictors of area burned: Journal of Range Management, v. 48, p. 85-91.

Knapp, P.A., 1996, Cheatgrass (Bromus tectorum) dominance in the Great Basin Desert. Global Environmental Change, v. 6, p. $37-52$.

Knick, S.T., Dobkin, D.S., Rotenberry, J.T., Schroeder, M.A., Vander Haegen, W.M., and van Riper, C., 2003, Teetering on the edge or too late? Conservation and research issues for avifauna of sagebrush habitats: Condor, v. 105, p. 611-634.

Knick, S.T., and Hanser, S.E., 2011, Connecting pattern and process in greater sage-grouse populations and sagebrush habitats, in, Knick, S.T., and Connelly, J.W., eds., Greater Sage-Grouse-Ecology and conservation of a landscape species and its habitats, Berkeley, California, University of California Press, Studies in Avian Biology, v. 38, p. 383-405.

Knick, S.T., Hanser, S.E., and Preston, K.L., 2013, Modeling ecological minimum requirements for distribution of greater sage-grouse leks-Implications for population connectivity across their western range, U.S.A.: Ecology and Evolution, v. 3 , no. 6 , p. $1,539-1,551$.

Knight, D.H., Jones, G.P., Reiners, W.A., and Romme, W.H., 2014, Mountains and plains - The ecology of Wyoming landscapes ( $2 \mathrm{~d}$ ed.): New Haven, Connecticut, Yale University Press, 338 p.

Knutson, K.C., Pyke, D.A., Wirth, T.A., Arkle, R.S., Pilliod, D.S., Brooks, M.L., Chambers, J.C., and Grace, J.B., 2014, Long-term effects of seeding after wildfire on vegetation in Great Basin shrubland ecosystems: Journal of Applied Ecology, v. 51, p. 1,414-1,424.

Laycock, W.A., 1967, How heavy grazing and protection affect sagebrush-grass ranges: Journal of Range Management, v. 20, p. 206-213.

Leonard, K.M., Reese, K.P., and Connelly, J.W., 2000, Distribution, movements and habitats of sage grouse Centrocercus urophasianus on the upper Snake River Plain in Idaho-Changes from 1950s to 1990s: Wildlife Biology, v. 6, p. 265-270.
Leu, M., and Hanser, S.E., 2011, Influences of the human footprint on sagebrush landscape patterns: implications for sage-grouse conservation, in Knick. S.T., and Connelly, J.W., eds., Greater Sage-Grouse-Ecology and conservation of a landscape species and its habitats: Berkeley, California, University of California, Studies in Avian Biology, v. 38, p. 253-271.

Littell, J.S., McKenzie, D., Peterson, D.L., and Westerling, A.L., 2009, Climate and wildfire area burned in the western U.S. ecoprovinces, 1916-2003: Ecological Applications, v. 19, p. 1,003-1,021.

Lysne, C.R., and Pellant, M., 2004, Establishment of aerially seeded big sagebrush following southern Idaho wildfires: Boise, Idaho, U.S. Department of the Interior, Bureau of Land Management, Idaho State Office, Technical Bulletin No. 2004-01, 14 p.

Mack, R.N., 1981, Invasion of Bromus tectorum L. into western North America-An ecological chronicle: Agro-Ecosystems, v. 7, p. 145-165.

Mack, R.N., and Pyke, D.A., 1983, Demography of Bromus tectorum-Variation in time and space: Journal of Ecology, v. 71, p. 69-93.

McAdoo, J.K., Boyd, C.S., and Sheley, R.L., 2013, Site, competition, and plant stock influence transplant success of Wyoming big sagebrush: Rangeland Ecology and Management, v. 66, p. 305-312.

McArthur, E.D., 1983, Taxonomy, origin, and distribution of big sagebrush (Artemisia tridentata) and allies (subgenus Tridentatae), in, Johnson, R.L., ed., First Utah Shrub Ecology workshop: Logan, Utah State University, College of Natural Resources, p. 3-11.

McArthur, E.D., and Stevens, R., 2004, Composite shrubs, in Monsen, S.B., Stevens, R., and Shaw, N.L., comps., 2004, Restoring western ranges and wildlands: Fort Collins, Colorado, U.S. Department of Agriculture, Forest Service, Rocky Mountain Research Station, General Technical Report, RMRS-GTR-136-vol-2, p. 493-537.

McIver, J., and Starr, L., 2001, Restoration of degraded lands in the interior Columbia River basin-Passive vs. active approaches: Forest Ecology and Management, v. 153, p. 15-28.

Melgoza, G., Nowak, R.S., and Tausch, R.J., 1990, Soil water exploitation after fire-competition between Bromus tectorum (cheatgrass) and two native species: Oecologia, v. 83 , p. $7-13$. 
Merrill, K.R., Meyer, S.E., and Coleman, C.E., 2012, Population genetic analysis of Bromus tectorum (Poaceae) indicates recent range expansion may be facilitated by specialist geonotypes: American Journal of Botany, v. 99, p. 529-537.

Meyer, S.E., Garvin, S.C., and Beckstead, J., 2001, Factors mediating cheatgrass invasion of intact salt desert shrubland, in McArthur, D.E., and Fairbanks, D.J., comps., Shrubland ecosystem genetics and biodiversityProceedings: Ogden, Utah, U.S. Department of Agriculture, Forest Service, RMRS-P-21, p. 224-232.

Meyer, S.E., and Monsen, S.B., 1991, Habitat-correlated variation in mountain big sagebrush (Artemisia tridentata ssp. vaseyana) seed germination patterns: Ecology, v. 72, p. 739-742.

Meyer, S.E., and Monsen, S.B., 1992, Big sagebrush seed germination patterns: subspecies and population differences: Journal of Range Management, v. 45, p. 87-93.

Meyer, S.E., Monsen, S.B., and McArthur, E.D., 1990, Germination response of Artemisia tridentata (Asteraceae) to light and chill: patterns of between-population variation: Botanical Gazette, v. 151, p. 176-183.

Miller, R.F., Chambers, J.C., and Pellant, M., 2014, A field guide for selecting the most appropriate treatment in sagebrush and piñon-juniper ecosystems in the Great Basin-Evaluating resilience to disturbance and resistance to invasive annual grasses, and predicting vegetation response: Fort Collins, Colorado, U.S. Department of Agriculture, Forest Service, Rocky Mountain Research Station, General Technical Report, RMRS-GTR-322, 68 p.

Miller, R.F., Chambers, J.C., Pyke, D.A., Pierson, F.B., and Williams, C.J., 2013, A review of fire effects on vegetation and soils in the Great Basin region-Response and ecological site characteristics: Fort Collins, Colorado, U.S. Department of Agriculture, Forest Service, Rocky Mountain Research Station, General Technical Report, RMRS-GTR-308, 126 p.

Miller, R.F., and Eddleman, L.L., 2001, Spatial and temporal changes of sage grouse habitat in the sagebrush biome: Corvallis, Oregon State University Agricultural Experiment Station, Technical Bulletin 151, 35 p.

Miller, R.F., and Heyerdahl, E.K., 2008, Fine-scale variation of historical fire regimes in sagebrush-steppe and juniper woodland-An example from California, USA: International Journal of Wildland Fire, v. 17, p. 245-254.
Miller, R.F., Knick, S.T., Pyke, D.A., Meinke, C.W., Hanser, S.E., Wisdom, M.J., and Hild, A.L., 2011, Characteristics of sagebrush habitats and limitations to long-term conservation, in Knick, S.T., and Connelly, J.W., eds., Greater Sage-Grouse-Ecology and conservation of a landscape species and its habitats: Berkeley, California, University of California, Press Studies in Avian Biology, v. 38 , p. $145-184$.

Miller, R.F., Svejcar, T.J., and West, N.E., 1994, Implications of livestock grazing in the Intermountain sagebrush region: plant composition, in Vavra, M., Laycock, W.A., and Pieper, R.D., eds., Ecological implications of livestock herbivory in the west: Denver, Colorado, Society for Range Management, p. 101-146.

Monsen, S.B., and Stevens, R., 2004, Seedbed preparation and seeding practices, in Monsen, S.B., Stevens, R., and Shaw, N.L., compilers, Restoring western ranges and wildlands: Fort Collins, Colorado, U.S. Department of Agriculture, Forest Service, Rocky Mountain Research Station, General Technical Report, RMRS-GTR-136-vol-1, p. 121-154.

Monsen, S.B., Stevens, R., and Shaw, N.L., compilers, 2004a, Restoring western ranges and wildlands: Fort Collins, Colorado, U.S. Department of Agriculture, Forest Service, Rocky Mountain Research Station, General Technical Report, RMRS-GTR-136-vol-1, p. 1-294, plus index.

Monsen, S.B., Stevens, R., and Shaw, N.L., Compilers, 2004b, Restoring western ranges and wildlands: Fort Collins, Colorado, U.S. Department of Agriculture, Forest Service, Rocky Mountain Research Station, General Technical Report, RMRS-GTR-136-vol-2, p. 295-698, plus index.

Monsen, S.B., Stevens, R., and Shaw, N.L., compilers, 2004c, Restoring western ranges and wildlands: Fort Collins, Colorado, U.S. Department of Agriculture, Forest Service, Rocky Mountain Research Station, General Technical Report, RMRS-GTR-136-vol-3, p. 699-884, plus appendixes and index.

Mueggler, W.F., 1950, Effects of spring and fall grazing by sheep on vegetation of the upper Snake River plains: Journal of Range Management, v. 3, p. 308-315.

Ogle S.M., Reiners, W.A., and Gerow, K.G., 2003, Impacts of exotic annual brome grasses (Bromus spp.) on ecosystem properties of northern mixed grass prairie: American Midland Naturalist, v. 149, p. 46-58.

Pechanec, J.F., and Stewart, G., 1949, Grazing spring-fall sheep ranges of southern Idaho: Washington D.C., U.S. Department of Agriculture, Circular 808, 35 p. 
Paruelo, J.M., and Lauenroth, W.K., 1996, Relative abundance of plant functional types in grasslands and shrublands of North America: Ecological Applications, v. 6, p. $1,212-1,224$.

Patterson, R.L., 1952, The sage grouse in Wyoming: Denver, Colorado, Sage Books, Wyoming Game and Fish Commission, $344 \mathrm{p}$.

Petersen, C.A., Villalba, J.J., and Provenza, F.D., 2014, Influence of experience on browsing of sagebrush by cattle and its impacts on plant community structure: Rangeland Ecology and Management, v. 67, p. 78-87.

Peterson, E.B., 2013, Regional-scale relationship among biological soil crusts, invasive annual grasses, and disturbance: Ecological Processes, v. 2, p. 2-8, doi:10.1186/2192-1709-2-2

Peterson, J.G., 1970, The food habits and summer distribution of juvenile sage grouse in central Montana: Journal of Wildlife Management, v. 34, p. 147-155.

Pierson, E.A., and Mack, R.N., 1990, The population biology of Bromus tectorum in forests-Distinguishing the opportunity for dispersal from environmental restriction: Oecologia, v. 84, p. 519-525.

Pierson, F.B., Williams, C.J., Kormos, P.R., and Al-Hamdan, O.Z., 2014, Short-term effects of tree removal on infiltration, runoff, and erosion in woodland-encroached sagebrush steppe: Rangeland Ecology and Management, v. 67 , p. $522-538$.

Ponzetti, J., McCune, B., and Pyke, D.A., 2007, Biotic soil crusts in relation to topography, cheatgrass, and fire in the Columbia Basin, Washington: Bryologist, v. 4, p. 706-722.

Pyke, D.A., 1995, Population diversity with special reference to rangeland plants, in West, N.E., ed., Biodiversity of rangelands: Logan, Utah State University, College of Natural Resources, Natural Resources and Environmental Issues, v. IV, p. 21-32.

Pyke, D.A., 2011, Restoring and rehabilitating sagebrush habitats, in Knick, S.T., and Connelly, J.W., eds., Greater Sage-Grouse - Ecology and conservation of a landscape species and its habitats: Berkeley, California, University of California Press, Studies in Avian Biology, v. 38, p. 531-548.

Pyke, D.A., Brooks, M.L., and D'Antonio, C., 2010, Fire as a restoration tool-A decision framework for predicting the control or enhancement of plants using fire: Restoration Ecology, v. 18, p. 274-284.

Pyke, D.A., Wirth, T.A., and Beyers, J.L., 2013, Does seeding after wildfires in rangelands reduce erosion or invasive species?: Restoration Ecology, v. 21, p. 415-421, doi:10.1111/rec.12021.
Ramakrishnan, A.P., Meyer, S.E., Fairbanks, D.J., and Coleman, C.E., 2006, Ecological significance of microsatellite variation in western North American populations of Bromus tectorum: Plant Species Biology, v. 21, p. $61-73$.

Reichenberger, G., and Pyke, D.A., 1990, Impact of early root competition on fitness components of four semiarid species: Oecologia, v. 85, p. 159-166.

Reisner, M.D., 2010, Drivers of plant community dynamics in sagebrush steppe ecosystems - Cattle grazing, heat and water stress: Corvallis, Oregon State University, Ph.D. dissertation, $270 \mathrm{p}$.

Reisner, M.D., Grace, J.B., Pyke, D.A., and Doescher, P.S., 2013, Conditions favouring Bromus tectorum dominance of endangered sagebrush steppe ecosystems: Journal of Applied Ecology, v. 50, p. 1,039-1,049, doi:10.1111/13652664.12097.

Rice, B., and Westoby, M., 1978, Vegetative responses of some Great Basin shrub communities protected against jackrabbits or domestic stock: Journal of Range Management, v. 31, p. 28-34.

Robertson, D.R., Nielsen, J.L., and Bare, N.H., 1966, Vegetation and soils of alkali sagebrush and adjacent big sagebrush ranges in North Park, Colorado: Journal of Range Management, v. 19, p. 17-20.

Romo, J.T., and Eddleman, L.E., 1987, Effects of Japanese brome on growth of bluebunch wheatgrass, Junegrass and squirreltail seedlings: Reclamation and Revegetation Research, v. 6, p. 207-218.

Roselle, L., Seefeldt, S.S., and Launchbaugh, K., 2010, Delaying sheep grazing after wildfire in sagebrush steppe may not affect vegetation recovery: International Journal of Wildland Fire, v. 19, p. 115-122.

Rosentreter, R., 2005, Sagebrush identification, ecology, and palatability relative to sage-grouse, in Shaw, N.L., Pellant, M., and Monsen, S.B., compilers, Sage-grouse habitat restoration symposium-Proceedings: Fort Collins, Colorado, U.S. Department of Agriculture, Forest Service, Rocky Mountain Research Station, RMRS-P-38, p. 3-15.

Rosentreter, R., and Belnap, J., 2001, Biological soil crusts of North America, in Belnap, J., and Lange, O.L., eds., Biological soil crusts: Structure, function, and management: Berlin, Germany, Springer-Verlag, p. 31-50.

Roundy, B.A., Young, K., Cline, N., Hulet, A., Miller, R.F., Tausch, R.J., Chambers, J.C., and Rau, B., 2014, Piñonjuniper reduction effects on soil temperature and water availability of the resource growth pool: Rangeland Ecology and Management, v. 67, p. 495-505. 
Sage, R.F., and Kubien, D.S., 2007, The temperature response of $\mathrm{C}_{3}$ and $\mathrm{C}_{4}$ photosynthesis: Plant Cell and Environment, v. 30 , p. $1,086-1,106$.

Sala, O.E., Lauenroth, W.K., and Gollucio, R.A., 1997, Plant functional types in temperate semi-arid regions, in Smith, T.M., Shugart, H.H., and Woodward, F.I., eds., Plant functional types: Cambridge, United Kingdom, Cambridge University Press, p. 217-233.

Salo, L.F., 2005, Red brome (Bromus rubens subsp. madritensis) in North America-Possible modes for early introductions, subsequent spread: Biological Invasions, v. 7, p. $165-180$.

Seastedt, T.R., Hobbs, R.J., and Suding, K.N., 2008, Management of novel ecosystems: are novel approaches required?: Frontiers in Ecology and Environment, v. 6, p. $547-553$.

Society for Ecological Restoration International Science and Policy Working Group, 2004, The SER international primer on ecological restoration, Version 2: Tucson, Arizona, Society for Ecological Restoration International, accessed April 30, 2009, at http:/www.ser.org/pdf/primer3.pdf.

Shaw, N.L., 2004, Production and use of planting stock, in Monsen, S.B., Stevens, R., and Shaw, N.L., compilers, Restoring western ranges and wildlands: Fort Collins, Colorado, U.S. Department of Agriculture, Forest Service, Rocky Mountain Research Station, General Technical Report, RMRS-GTR-136-vol-3, p. 745-768.

Shepherd, J.F., Reese, K.P., and Connelly, J.W., 2011, Landscape fragmentation and nonbreeding greater sage-grouse, in Sandercock, B.K., Martin, K., and Segelbacher, G., eds., Ecology, conservation, and management of grouse: Berkeley, California, University of California Press, Studies in Avian Biology, v. 39, p. 77-88.

Shiflet, T.N., ed., 1994, Rangeland cover types of the United States: Denver, Colorado, Society for Range Management, p. 152 .

Shultz, L.M., 2009, Monograph of Artemisia subgenus tridentata (Asteraceae- Anthemideae): Systematic Botany Monographs, v. 89, p. 131.

Shultz, L.M., 2012, Pocket guide to sagebrush: Point Reyes Bird Observatory Conservation Science, 85 p.

Stiver, S.J., Apa, A.D., Bohne, J.R., Bunnell, S.D., Deibert, P.A., Gardner, S.C., Hilliard, M.A., McCarthy, C.W., and Schroeder, M.A., 2006, Greater Sage-grouse comprehensive conservation strategy: Cheyenne, Wyoming, Unpublished report on file at Western Association of Fish and Wildlife Agencies, 28 p.
Strand, E.K., Launchbaugh, K.L., Limb, R., and Torell, L.A., 2014, Livestock grazing effects on fuel loads for wildland fire in sagebrush dominated ecosystems: Journal of Rangeland Applications, v. 1, p. 35-57.

Taylor, J., Toevs, G., Karl, J., Bobo, M., Karl, M., Miller, S., and Spurrier, C., 2012, AIM-monitoring-A component of the BLM assessment, inventory, and monitoring strategy: Denver, Colorado, U.S. Department of the Interior, Bureau of Land Management, National Operations Center, 10 p.

Terri, J.A., and Stowe, L.G., 1976, Climatic patterns and the distribution of $\mathrm{C}_{4}$ grasses in North America: Oecologia, v. 23, p. 1-12.

Toledo, D., Herrick, J.E., and Abbott, L.B., 2010, A comparison of cover pole, with standard vegetation monitoring methods: Journal of Wildlife Management, v. 74 , p. $600-604$.

U.S. Department of Agriculture, 2014, PLANTS database: U.S. Department of Agriculture Natural Resources Conservation Service, accessed December 15, 2014, at http://plants.usda.gov/.

U.S. Fish and Wildlife Service, 2013, Greater Sage-grouse (Centrocercus urophasianus) conservation objectivesFinal report, February 2013 : Denver, Colorado, U.S. Fish and Wildlife Service, 62 p., plus appendixes.

U.S. General Accounting Office, 1977, Public rangelands continue to deteriorate: Washington, D.C., U.S. General Accounting Office Report CED-77-88, 28 p.

Walker, B.L., Naugle, D.E., and Doherty, K.E., 2007, Greater Sage-grouse population response to energy development and habitat loss: Journal of Wildlife Management, v. 71, p. 2,644-2,654.

Wambolt, C.L., and Payne, G.F., 1986, An 18-year comparison of control methods for Wyoming big sagebrush in southwestern Montana: Journal of Range Management, v. 39 , p. 314-319.

Wambolt, C.L., and Watts, M.J., 1996, High stocking rate potential for controlling Wyoming big sagebrush, in Barrow, J.R., McArthur, E.D., Sosebee, R.E., and Tausch, R.J., compilers, Proceedings-Shrubland ecosystem dynamics in a changing environment, May 23-25,1995, Las Cruces, New Mexico: Ogden, Utah, U.S. Department of Agriculture, Forest Service, Intermountain Research Station, General Technical Report INT-GTR-338, p. $148-150$.

Wambolt, C.L., Walhof, K.S., and Frisina, M.R., 2001, Recovery of big sagebrush communities after burning in south-western Montana: Journal of Environmental Management, v. 61, p. 243-252. 
Welch, B.L., and Criddle, C., 2003, Countering misinformation concerning big sagebrush: Ogden, Utah, U.S. Department of Agriculture, Forest Service, Rocky Mountain Research Station, Research Paper RMRS-RP-40, $28 \mathrm{p}$.

Welty, J.L., and Pilliod, D.S., 2013, Data entry module and manuals for the land treatment digital library: U.S. Geological Survey Data Series 749, http://pubs.usgs.gov/ ds/749.

West, N.E., 1983, Overview of North American temperate deserts and semi-deserts, in West, N.E., ed., Temperate deserts and semi-deserts: Amsterdam, The Netherlands, Elsevier Publishing Company, Amsterdam, The Netherlands, p. 321-330.

West, N.E., Provensa, F.D., Johnson, P.S., and Owens, D.K., 1984, Vegetation changes after 13 years of livestock grazing exclusion on sagebrush semidesert in west central Utah: Journal of Range Management, v. 37, p. 262-264.

West, N.E., and Young, J.A., 2000, Intermountain valleys and lower mountain slopes, in Barbour, M.G., and Billings, W.D., eds., North American terrestrial vegetation ( $2 \mathrm{~d}$ ed.): Cambridge, United Kingdom, Cambridge University Press, p. 256-284.

Westerling, A.L., Hidalgo, H.G., Cayan, D.R., and Swetnam, T.W., 2006, Warming and earlier spring increase U.S. forest wildfire activity: Science, v. 313, p. 940-943.

Whisenant, S.G., 1990, Postfire population dynamics of Bromus japonicus: The American Midland Naturalist, v. 123, p. 301-308.
White, R.S., and Currie, P.O., 1983, Prescribed burning in the northern Great Plains-yield and cover responses of 3 forage species in the mixed grass prairie: Journal of Range Management, v. 36, p. 179-183.

Whitson, T.D., 1996, Weeds of the west (5 ed.): Laramie, Wyoming, University of Wyoming, Western Society of Weed Science in cooperation with Cooperative Extension Services, $630 \mathrm{p}$.

Wijayratne, U.C., and Pyke, D.A., 2012, Burial increases seed longevity of two Artemisia tridentata (Asteraceae) subspecies: American Journal of Botany, v. 99, p. 438-447.

Wisdom, M.J., and Chambers, J.C., 2009, A landscape approach for ecologically-based management of Great Basin shrublands: Restoration Ecology, v. 17, p. 740-749.

Wisdom, M.J., Meinke, C.W., Knick, S.T., and Schroeder, M.A., 2011, Factors associated with extirpation of sage-grouse, in Knick, S.T., and Connelly, J.W., eds., Greater Sage-Grouse-Ecology and conservation of a landscape species and its habitats. Berkeley, California, University of California Press, Studies in Avian Biology, v. 38 , p. $451-474$.

Young, J.A., and Sparks, B.A., 2002, Cattle in the cold desert: Reno, Nevada, University of Nevada Press, 317 p.

Young, S., 1995, Alternative germplasm release procedures for producing certified seed: Seed World, v. 133, p. 14-15. 


\section{Appendix A. Scientific Name with Synonyms and Corresponding Common Name with Synonyms for Species Referenced in This Report}

[From U.S. Department of Agriculture, 2014. sp., species not specified; spp., several species; ssp., subspecies]

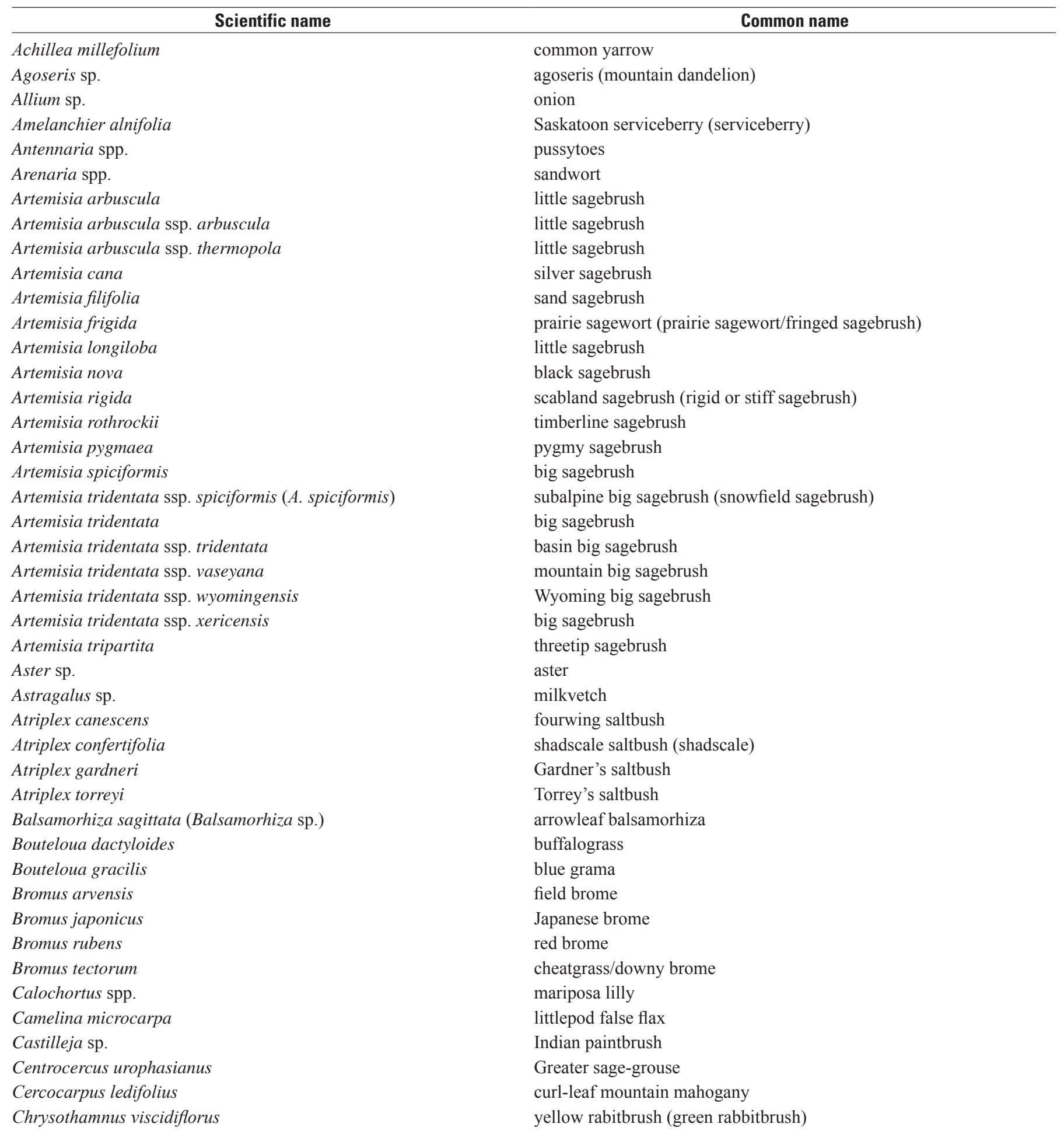


42 Restoration Handbook for Sagebrush Steppe Ecosystems with Emphasis on Greater Sage-Grouse Habitat—Part 1

Appendix A. Scientific Name with Synonyms and Corresponding Common Name with Synonyms for Species Referenced in this Report-Continued

[From U.S. Department of Agriculture, 2014. sp., species not specified; spp., several species; ssp., subspecies]

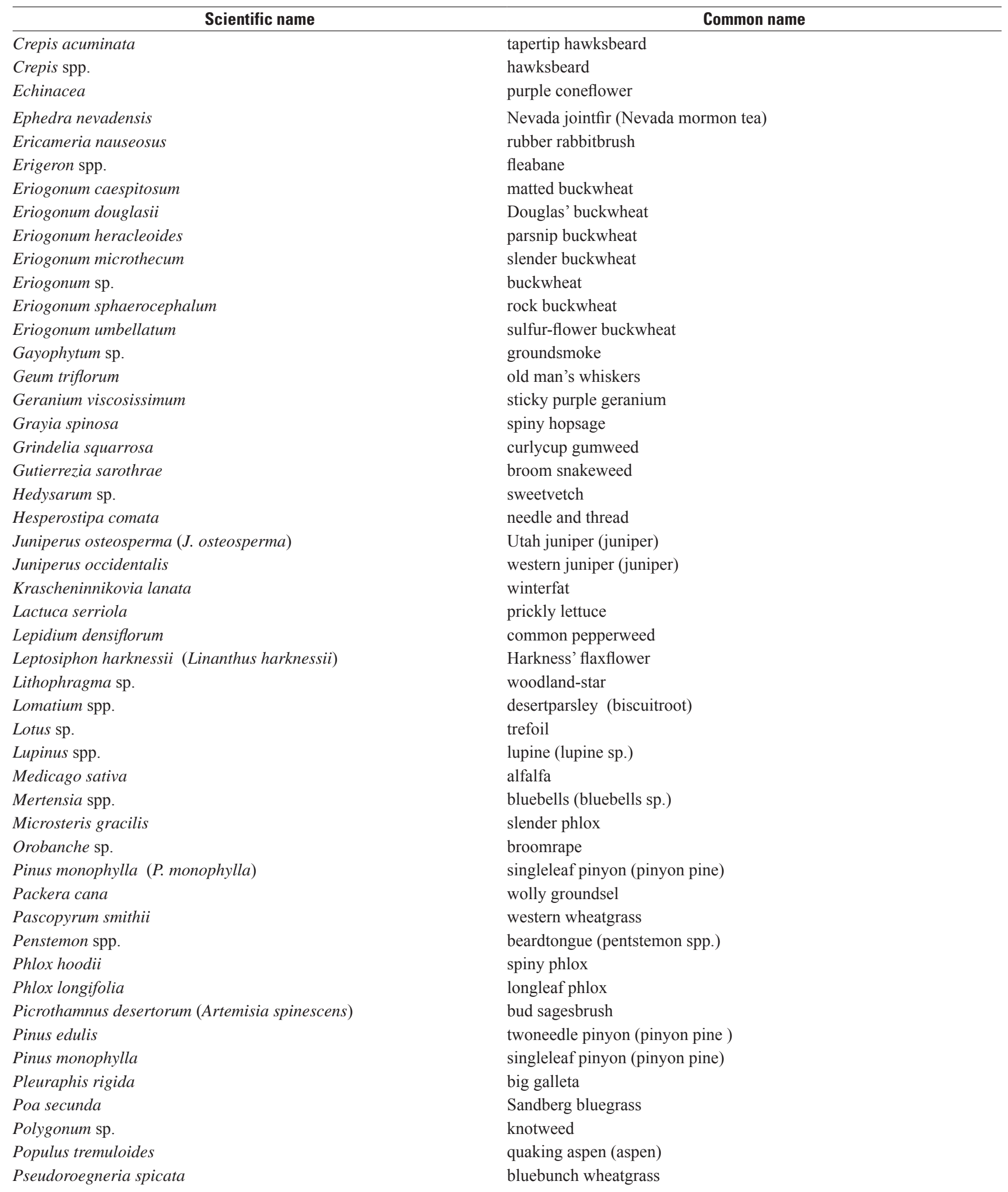


Appendix A. Scientific Name with Synonyms and Corresponding Common Name with Synonyms for Species Referenced in this Report-Continued

[From U.S. Department of Agriculture, 2014. sp., species not specified; spp., several species; ssp., subspecies]

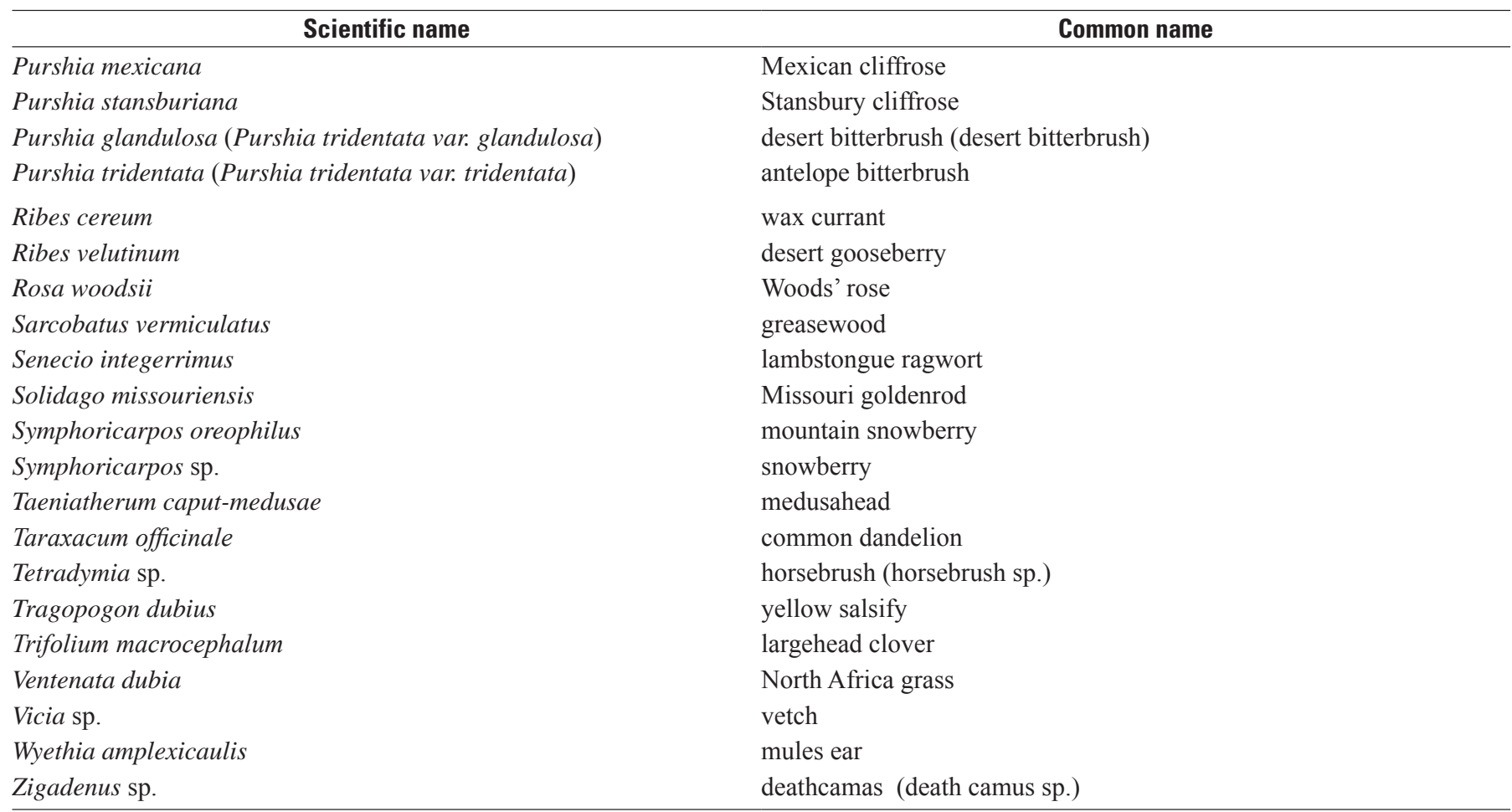



Publishing support provided by the U.S. Geological Survey Science Publishing Network, Tacoma Publishing Service Center

For more information concerning the research in this report, contact the Director, Forest and Rangeland Ecosystem Science Center U.S. Geological Survey

777 NW 9th St., Suite 400

Corvallis, Oregon 97330

http://fresc.usgs.gov 
